\title{
Housing Tenure and Unemployment
}

\author{
Richard K. Green ${ }^{1}$ \\ Bingbing Wang ${ }^{2}$
}

June 1,2015

\begin{abstract}
In this article, we test whether tenure choice influences employment. This influence might arise through a number of channels, including transaction costs, lock-in effects, wealth effects, externalities and commuting times. These factors could collectively have either a positive or negative effect on employment outcomes. Using Current Population Survey panel data from 1988 to 2013, we conclude that tenure rates do not statistically influence employment growth rates. Using Panel Study of Income Dynamics data from 1994 to 2011 and Survey of Income and Program Participation data from 1995 to 2013, we conclude that home-owning does not increase peoples' unemployment probabilities or significantly increase people's unemployment spells or decrease people's wages. But home-owning does affect employment by lengthening employment durations and increasing the likelihood of interstate moves. By investigating some features of home-owing- presence of mortgages, negative equity, wealth accumulation and attachment to communities-we conclude that having mortgages, negative equity and wealth accumulation might affect job outcomes, largely in a positive direction.
\end{abstract}

Keywords: homeownership, employment, mortgages, negative equity, wealth accumulation $\mathrm{R} 23, \mathrm{C} 23, \mathrm{C} 41, \mathrm{E} 24$

\footnotetext{
${ }^{1}$ Lusk Center for Real Estate, University of Southern California, Los Angeles, CA 90089-0626 or keynesian.richard@gmail.com

${ }^{2}$ Lusk Center for Real Estate, University of Southern California, Los Angeles, CA 90089-0626 or bingbingwang123@gmail.com
} 


\section{Introduction}

A burgeoning literature is investigating the relationship between home-ownership and employment. At this point, the literature has not reached any consensus about this issue. Indeed, some papers by themselves produce ambivalent results.

Oswald and Blancheflower (1994, 1997, and 1999) kicked off the debate about homeowning and employment with a controversial paper that found positive correlations between unemployment and lagged home-ownership across the 50 states in the U.S. and countries in the EU. This paper, while provocative, had little in the way of controls; it was particularly lacking in a mechanism for dealing with the fact that people who chose to be immobile would find homeownership financially more rewarding, because they are more likely to be able to amortize the large transactions costs involved in buying a house. In a later paper with fixed effects, however Oswald and Blancheflower (2013) continued to find that home-owning led to unemployment. On the other hand, Munch (2006) used household level data from Denmark to show that homeowners have better job outcomes. Table 1 provides a detailed literature summary.

The remainder of this article contains four sections. First, we conjecture about frameworks through which home-ownership might affect the labor market. Second, we discuss some of the identification issues that make any attempt to find a causal relationship between home-owning and employment difficult. Third, we show that simply changing the specification of the left hand side variable from unemployment to employment growth changes the apparent relationship between home-ownership and employment outcomes. Fourth, we show that there are no significant differences in owners and renters' unemployment probabilities, unemployment spells and wages. But homeowners' employment spell lengths are longer and their probability of 
moving to other states and counties is higher. And the specific owning features of having mortgages, negative equity and wealth accumulation contribute to those differences. We summarize our findings in the Tables 2 and 3 below. Finally, we conclude.

Table 2: The impact of home-ownership on employment outcomes:

\begin{tabular}{ll}
\hline \hline Result & Home-ownership effect \\
\hline Unemployment rate & Higher ownership rates might lead to slightly higher unemployment rates \\
Employment growth rate & Ownership rates don't affect employment growth rates \\
Unemployment probability & Slightly less likely to be unemployed \\
Unemployment spell & No longer unemployment spells \\
Employment spell & A little longer employment spells \\
Mobility & $\begin{array}{l}\text { Not less likely to move for jobs (PSID); more likely to move to other states } \\
\text { and counties (SIPP) }\end{array}$ \\
Wages & No difference \\
\hline
\end{tabular}

Table 3: Homeowner characteristic effects-working mechanisms:

\begin{tabular}{lllll}
\hline \hline & Mortgage & Negative equity & Wealth & $\begin{array}{l}\text { Attachment to } \\
\text { community }\end{array}$ \\
\hline $\begin{array}{l}\text { Unemployment } \\
\text { probability }\end{array}$ & No effect & No effect & $\begin{array}{l}\text { Less likely to be } \\
\text { unemployed }\end{array}$ & No effect \\
\hline $\begin{array}{l}\text { Unemployment } \\
\text { spell }\end{array}$ & $\begin{array}{l}\text { Slightly elongate } \\
\text { unemployment (stay } \\
\text { put) }\end{array}$ & $\begin{array}{l}\text { More likely to } \\
\text { leave } \\
\text { unemployment } \\
\text { (default) }\end{array}$ & $\begin{array}{l}\text { Slightly less likely } \\
\text { to leave } \\
\text { unemployment }\end{array}$ & $\begin{array}{l}\text { Slightly more } \\
\text { likely to leave } \\
\text { unemployment }\end{array}$ \\
\hline $\begin{array}{l}\text { Employment } \\
\text { spell }\end{array}$ & $\begin{array}{l}\text { Elongate } \\
\text { employment (stay } \\
\text { put) }\end{array}$ & $\begin{array}{l}\text { More likely to } \\
\text { leave employment } \\
\text { (default) }\end{array}$ & $\begin{array}{l}\text { Less likely to } \\
\text { leave employment }\end{array}$ & No effect \\
\hline $\begin{array}{l}\text { Moving } \\
\text { probability }\end{array}$ & $\begin{array}{l}\text { More likely to move } \\
\text { to different states and } \\
\text { counties (SIPP 2008) }\end{array}$ & No effect & $\begin{array}{l}\text { Less likely to } \\
\text { move for jobs }\end{array}$ & $\begin{array}{l}\text { Less likely to } \\
\text { move for jobs }\end{array}$ \\
\hline
\end{tabular}




\section{Framework}

Search theory gives reasons why homeowners might be at a disadvantage in the labor market; it also gives reasons why they might be at an advantage. Homeowners might find labor market search inhibited by the tendency of owners to live in suburbs, where people tend to have long commutes. They may also be impeded by low mobility rates, owing to high moving costs, high selling costs, and attachment to community.

On the other hand, home-owning might help workers attach to good jobs. For example, Coulson and Fisher (2002) show that employers like locating in cities where labor is less mobile, because the pool of available labor is more reliable. Hence, it is the immobility of homeowners that produces better job market outcomes. Homeowners are also wealthier than renters, in part because of wealth accumulated through home-ownership, and therefore might, in the presence of unemployment, have the resources to take the time to search for a good job match. This means homeowners might have longer unemployment spells (Goss and Phillips, 1997). Homeowners might stay longer and work harder in their job positions to meet burdens of mortgage payments (Goss and Phillips, 1997; Flatau et al., 2003). They might also search harder for local jobs and have lower reservation wages for local jobs to avoid moving (Goss and Phillips, 1997; Munch, 2006). On the other hand, firms are willing to pay more to workers to encourage long term employment (Farber, 1998), thereby avoiding the cost of turnover.

Oswald and Blanchflower (2013) posit that home-ownership creates negative externalities for the labor market. The reason is that homeowners tend to block the construction of the facilities that produce nuisances to their community but are beneficial for the whole economy. Homeowners also tend to engage in fiscal zoning, blocking out low-to-moderate 
income people on the grounds that they cost more in government service than they pay in taxes (Fischel, 2004). This behavior, however, prevents employers from having access to the full range of labor they need. Coulson and Fisher (2009) find that the unemployment probability is increased for both homeowners and renters when the regional home-ownership rate increases.

The issue of the impact of home-ownership on labor mobility has become particularly germane in the aftermath of the financial crisis. A debate-related to but separate from the one

discussed here-has developed regarding whether negative equity homeowners are more or less likely to move for job opportunities (Ferreira, Gyourko, and Tracy, 2010; Schulhofer-Wohl, 2010; Mumford, 2013). Moreover, during the aftermath of the financial crisis, some scholars hypothesized that some underwater homeowners were locked into their homes and were therefore unable to move to job opportunities in other places. Recent empirical evidence, however, is mixed about whether underwater borrowers are more or less likely to move for a job. We will discuss this literature later in the paper.

\section{Commuting Time}

Oswald argues home-ownership may elongate commuting time for work and create a less mobile labor force. This increased cost of commuting hurts employees and employers both (Oswald 2013). Burnley (1997), by studying decentralizing moves within Sydney, finds that home-ownership is highly correlated with commuting times. Homeowners move to the suburbs for larger houses, even if the employment opportunities are fewer and their commuting times are longer. And the desire to own a relatively larger and higher quality house and the tax benefits associated with such a house might contribute to the development of urban forms like urban sprawl (Voith, 1999). But there might be other, more important reasons for sprawl. For example, 
reverse commutes from centers to suburbs are common (Fischel, 2004), because employment opportunities have also moved to the suburbs. Munch (2006) shows that in Denmark, homeowners have a higher hazard rate into employment for intra-state jobs, since owners are more willing to travel long distances to avoid moving for jobs.

\section{High transaction cost}

Home-ownership may lower peoples' willingness to move. If owners are less willing to move, they are less likely to be flexible about relocating in response to unemployment. There is no question that on average owners are less likely to move than renters. According to the American Community Survey, the median length of tenure for renters in 2011 was 3 years while the median length of tenure for owners in 2011 was 9 years.

Oswald asserts that years in which the ownership rate is increasing are also years in which mobility is decreasing. His regression analysis also shows a negative relationship between home-ownership and mobility (Oswald, 2013).

\section{Lock-in effect}

Negative equity, loss aversion, property tax benefits and mortgages with interest rates below market rates might all discourage homeowners from moving. We discuss the potential impact of each of these phenomena in turn.

Homeowners who buy houses with high loan-to-value ratios (LTVs) may find themselves with negative equity when house prices decrease. The problem facing borrowers with negative equity when they wish to move is that they face unpleasant choices: they can either bring cash to the sale so as to discharge their obligation to the lender; they can default and thus compromise 
their credit history; or they can keep their house in one job market while renting a house in another job market (Stein, 1995; Chan, 2001; Ferreira, Gyourko and Tracy, 2010; S SchulhoferWohl, 2011).

Stein (1995) argues that falling house prices create a self-reinforcing down payment effect on house prices in the aftermath of an initial negative shock. For example, consider a family that puts $\$ 40,000$ down on a $\$ 200,000$ house in a world where the standard downpayment is 20 percent. If the value of the house falls by 10 percent, the family's equity is cut in half, meaning that a consequence of moving might be to live in a $\$ 100,000$ house. The family might rationally conclude that it is better off staying put than downsizing. This will lead to a decline in housing demand. However, this family's decision to stay put also puts downward pressure on housing supply. Whether the supply or demand effect is strengthened depends on (1) the sizes of the shifts and (2) the relative elasticities of the demand and supply curves for housing. It is therefore hard to make general predictions based on Stein (1995)'s mechanism.

House price shocks could be self-reinforcing, however, if they change house price expectations. If expectations turn negative, the supply of housing on the market could increase, as households seek to shed an asset whose value they expect to deteriorate, while the demand for housing could decrease for exactly the same reason. Similarly, investors in houses might want to sell to limit their losses. This might also have a self-reinforcing effect. This self-enforcing effect on prices might create large number of households with negative equity, which might lock people into their houses.

But the negative equity lock-in effect might be minor (Engelhardt, 2003). For large numbers of homeowners, negative house price shocks are, while upsetting, not particularly 
material. For example, homeowners who don't want to move and don't invest in multiple houses may just reduce their spending in the presence of falling house prices ${ }^{3}$ or refinance; those wishing to move with high LTV ratios may wait for the market to recover, and might therefore be briefly locked in if they find the call value of potentially positive home equity to be more valuable than the income earned from a new job; on the other hand, owners who have low LTV ratios and who are therefore not liquidity constrained may just decide to take their losses and move $^{4}$. Consequently, the negative equity effect might only affect mobility when a material share of those considering moving for better employment opportunities have (1) high LTV ratios and (2) perceive the value of the call option embedded in the house to be high.

For potential sellers with nominal loss aversion--homeowners unwilling to sell their houses at prices lower than the purchase price--house price decreases could impede mobility (Genesove and Mayer, 1997, 2001; Chan, 2001; Engelhardt, 2003; Ferreira, Gyourko and Tracy, 2010).

Ferreira (2010) argues that Proposition 13 in California has also created a lock-in effect in that state. Proposition 13 states that homeowners' property tax should be no more than 1 percent of their house price at the time of purchase, plus an annual adjustment of no more than 2 percent if they do not move. Thus when house prices in California rise sharply, homeowners are less inclined to move, in order to keep their property tax benefits. Quigley (1987) finds that homeowners with favorable mortgage interest rates are less likely to move as well, so as to keep their low mortgage interest rate if their mortgage loan is non-assumable.

\footnotetext{
${ }^{3}$ See Engelgardt (2003).

${ }^{4}$ Unless these potentially sellers decided not to do so because of nominal loss aversion. See Genesove and Mayer (2001).
} 
Multiple studies after the financial crisis, however, show that the lock-in effect after 2007 has been non-existent (Donovan, 2011; Aaronson, 2011; Schulhofer-Wohl, 2012; Mumford, 2013). Possible explanations might be that because interest rates have been quite low since 2007, homeowners are not motivated by low rates to avoid moving. With respect to Proposition 13, because house prices were decreasing between 2007 and 2012, many homebuyers purchasing houses in California are not currently paying property taxes based on their home value at time of purchase, but rather on the actual market value of their house.

As for negative equity, after the financial crisis, many households, particularly in Nevada, Arizona, California, Florida, Michigan and Ohio, were deeply underwater on their mortgages. This means that the embedded call value on their property was quite low, so that the incentive to remain in the house to exercise potentially their option has been quite low. So those homeowners should be just as likely, if not more likely, to choose strategic foreclosures or short sales over remaining locked in. The difference of the effects comes from the fact that the relationship between negative equity and mobility is nonlinear. Before the crisis, house price decreases tended to be modest and therefore insufficient to drive people to default or transact a short-sale. But after the financial crisis, homeowners with underwater mortgages chose to default because of an absence of hope of ever repaying the mortgages. The incentives to default were especially strong when the loans did not carry recourse (Schulhofer-Wohl, 2012).

The loss aversion effect also disappeared in the aftermath of the crisis. Homeowners with loss aversion simply rented their houses out and moved elsewhere (Schulhofer-Wohl, 2012). In short, under extreme circumstances, owners will choose the right financial strategic move instead of allowing themselves to be locked in. Donovan (2011) shows that interstate mobility, which mostly happens for job opportunities, actually shows no decline and is higher in counties with 
greater house price declines. Homeowners with tremendous negative equity are more mobile than those with small negative equity (Aaronson, 2011; Schulhofer-Wohl, 2012; Mumford, 2013).

In conclusion, the lock-in effect from negative equity and loss aversion depends on homeowner expectations, and the depth of the negative equity. In a world of rational actors, expectations might depend on patterns of housing price change and economic conditions, including the durations and magnitudes of price declines. But Case and Shiller (1988) show that homeowners don't form rational perceptions or expectations about market change, unless the change is severe. The financial crisis was exceptionally severe, and so jolted into understanding the true nature of the markets in which they were participating. All of this implies that lock-in effects are more likely to appear when homeowners are not completely cognizant of market signals, so fail to adjust to those signals by moving. In the face of overwhelming evidence of a changing market, however, homeowners become quite rational and make moves that are in their best economic interest. This explains why owning sometimes locks people in and sometimes it doesn't.

\section{Externality}

Homeowners have a strong interest in preserving the value of their homes. Consequently, they may form neighborhood groups that fight any development perceived as having a negative impact on their house values (Fischel, 2004; Oswald, 2013). The mechanism for impeding development is stringent zoning. Such zoning can prevent the creation of jobs. Consequently, home-ownership might create a spillover effect on the labor market. 
Fischel (2004) argues that fiscal zoning can lead cities to have inefficient spatial structures. Communities will institute zoning that puts a floor on the effective construction cost of new housing. By doing so, communities can assure that there is (1) a large real estate tax base per inhabitant and (2) that they have to spend relatively little on the provision of social services. Again, homeowners will tend to support such zoning, because they perceive that it will cause their house to be more valuable. The result of this, however, is that many people are zoned out of some municipalities, which in turn can lead to, at best, inefficient commutes and, at worst, spatial isolation (Kane, 1968).

If homeowners are a majority, they would have the political power to preserve existing housing subsidies for tax benefits, such as the U.S. mortgage interest deduction. Mortgage providers, real estate companies, and home builders also use the majority status of homeowners to argue on behalf of subsidies that benefit them. A particularly important example of this was the ability of the real estate industry to preserve the deductibility of mortgage interest during the development of the Tax Reform Act of 1986, an act that eliminated the deductibility of all other consumer interest.

This subsidy produces two types of inefficiencies: it encourages home buyers to take on debt, which could lead to an increase in the cost of capital; it also encourages home buyers to buy larger houses than they otherwise might, thus steering capital away from more productive plant and equipment. Together, these distortions could reduce long-term economic growth (Mills, 1987). On the other hand, the tax deductibility of the property tax and mortgage interest payments reduces the income tax burden on homeowners. Lower effective wage taxes should increase both the demand and supply of labor (Nickell, 1998). 
Homeowners may also contribute more to their communities owing to their long residence, better maintenance and involvement in their housing as well as their communities. This social capital building might create positive externalities and improve employment (Green and Hendershott, 2001; Coulson and Fisher, 2009). Studies also show that a better living structure is associated with better mental health (Evans, 2003). Homeowners' children are more likely to attend college and spend more time in school (Kane, 1994; Green and White, 1997).

Returning to the negative externalities, high home-ownership rates might increase job mismatch levels (Estevao and Tsounta, 2011). Munch (2006) suggests that homeowners might have a lower reservation wage due to their high preference for local jobs and this might result in lower job match levels and possibly crowd out renters from local labor markets. Coulson and Fisher (2009), after correcting for selection bias, find that wages are lower for homeowners than renters, which might suggest that homeowners indeed lower their reservation wages. And when home-ownership rates increase, owners and renters are both more likely to be unemployed, especially renters (Coulson and Fisher, 2009). Aside from the fact that the renters might be crowded out of the labor market by local homeowners, owners also crowd out the private rental market, potentially producing higher moving and transaction costs for renters. Finally, subsidized housing consumption might crowd out current and prospective homeowners' other consumption (Laamanen, 2013).

\section{Wealth and investment effect}


People become homeowners not just for living but also for accumulating assets to hedge against uncertainties $\left(\right.$ Gallup ${ }^{5}$ ). Homeowners might thus better cope with economic difficulties and consume more. Increased consumption can help create more job opportunities. Also, homeowners are better able to move and smooth the transition period from the sale of their houses (Green and Hendershott, 2001). Further, wealth might help owners to be more stable in their current house, allowing them to accumulate more wealth. Alternatively, households may perceive housing as hedge against uncertainties, or a long term saving device, meaning that changes in home-owning wealth do not affect current consumption (Elliott, 1980). Owners may perceive housing value changes as temporary, and thus do not change their consumption in response to changes in values (Case, Quigley and Shiller, 2005).

Wealth effects may be nonlinear in house prices. If house prices are high, down payment requirements and monthly installments would motivate potential homebuyers to save and therefore crowd out consumption (Engelhardt and Mayer, 1994). The wealth effect may also vary during economic booms and busts. Case (1992) found significant consumption effects during the real estate boom in New England in the 1980s. Engelhardt (1996) finds that households with real estate value gains do not change their consumption much, but do reduce their consumption when there are losses. This implies that prospect theory might explain observed wealth effects: homeowners may be more sensitive to losses than gains.

Apart from the wealth effect, an investment effect might also exist because real estate is closely connected with its upstream and downstream industries, like steel, construction and mortgages. Countries that favor home-ownership may have more active real estate markets, thus

\footnotetext{
5

5 Gallup's annual Economy and Finance survey, conducted April 4-14 with more than 2,000 Americans, including 1,406 homeowners and 496 renters on the topic of housing.
} 
improving their economies (Wen, 2001). However, overinvestment in real estate might hurt employment because housing's return is lower than on other types of capital (Mills, 1987).

\section{Challenges: Endogeneity}

The most serious empirical challenge for micro-level research is endogeneity. This problem arises when there are unobserved factors influencing both the dependent and the independent variables. What we are interested in is: for the same person, whether homeownership affects his or her employment performance and moving decisions for work; whether their employment performance and moving probabilities are affected by the pressure from having to meet a mortgage payment, by negative equity, by wealth accumulation or by community involvement; whether they are less willing to move to the extent that they settle for a less desirable job and whether this behavior crowds out the most optimal matches.

However, in practice, to test those effects we can only compare homeowners and renters. It is quite likely that the owners are disproportionately more successful in job performance than renters. The people who are more able, more inclined to settle down, and have more income, are also more likely to be homeowners. At the same time, more able people may be better at their jobs; and those who want to settle may work harder to keep their local jobs or search harder for local jobs. This is particularly important in light of the fact that mortgage underwriting depends in part on job history (Goss and Phillips, 1997). As for mobility, those households that are more likely to move are also more likely to decide to be renters (Haurin and Gill, 2002).

Existing literature uses the Heckman two step method (Green and Hendershott, 2001), simultaneous equations (Leuvensteijn and Koning, 2004; Munch, 2006 and 2007) and IV to solve this class of problem (Coulson and Fisher, 2009; Laamanen, 2013). The Heckman two step 
method first models the probability of becoming a homeowner and uses the predicted homeownership probability as the explanatory variable to model the different employment and unemployment outcomes. Simultaneous equations model the home-ownership decision and unemployment probability simultaneously to correct for the endogeneity by allowing the error terms for the two equations to be correlated. Laamanen (2013) uses rental housing market deregulation as an instrumental variable. This reform affects home-ownership decisions but not unemployment spells or unemployment probabilities. Using panel data to difference out the unobservable time invariant factors can also help to obtain the net effect of the treatment variable on employment status.

\section{Data, Methodology and Results}

The theoretical literature on housing and labor markets shows that home-owning might be beneficial, detrimental or neutral. If the negative effect dominates, on the individual level, we would expect that homeowners will have higher unemployment probabilities, longer unemployment spells and lower wages than renters. And because homeowners bear higher transactions cost for moving, they should be less likely to move and more likely to be locked-in during a real estate bust. Homeowners with underwater mortgages might have lower mobility rates which could impede the ability to search for jobs, and therefore lead to worse employment outcomes. On the other hand, debt is a disciplining device, which might induce people to stay employed longer than they otherwise might.

If there is negative externality from home-owning, a higher state home-ownership rate might lead to worse employment outcomes for both owners and renters: both might be more likely to be unemployed, have longer unemployment spells and lower wages. If this is true, we 
would in aggregate expect that higher home-ownership rates lead to higher unemployment rates and lower employment growth rates.

At the same time, it is also possible that homeowners are more stable and committed to their local jobs. Additionally, so long as owners have positive equity, they have resources to pay for such things as moving costs, enabling them better to seize new job opportunities elsewhere. How tenure choice affects employment outcomes is therefore an empirical question.

Our empirical results are divided into six parts. We first present aggregate level results: whether higher home-ownership rates lead to higher unemployment rates and lower employment growth rates. We use Current Population Survey Merged Outgoing Rotation Groups (CPS MORG) data for the investigation. Parts two through six are based on the individual level data from the Panel Study of Income Dynamics (PSID) and Survey of Income and Program Participation (SIPP). Part two tests whether homeowners are more likely to be unemployed than renters and whether higher home-ownership rates render both owners and renters more likely to be unemployed. Part three investigates the length of unemployment and employment spells for owners and renters and the effect of state home-ownership rates on the spells. Part four explores whether home-owning decreases people's mobility. Part five looks at whether wages differ between owners and renters. Finally, we investigate how the various characteristics from homeowning can explain why owners' employment outcomes are what they are. For the PSID data we provide results for both family heads and "wives" .

\section{A. Macro relationship between employment growth and home-ownership rates}

\footnotetext{
${ }^{6}$ PSID: Within each wave of data, each FU (family unit) has one and only one current Head. Originally, if the family contained a husband-wife pair, the husband was arbitrarily designated the Head to conform with Census Bureau definitions. The Head of the FU must be at least 16 years old and the person with the most financial responsibility for the FU. If this person is female and she has a husband in the FU, then he is designated as Head. If she has a boyfriend with whom she has been living for at least one year, then he is Head. However, if the husband or boyfriend is incapacitated and unable to fulfill the functions of Head, then the FU will have a female Head from https://psidonline.isr.umich.edu/Guide/FAQ.aspx?Type=ALL
} 
We first test whether on the aggregate level home-owning has a negative effect on overall employment. For completeness, we look at the state level home-ownership rate effects on both employment and unemployment. Blanchflower and Oswald (2013) obtained a negative effect from home-owning on employment and a positive effect on unemployment. For the left-hand side variable, they used log employment rates and unemployment rates. We keep the $\log$ unemployment rates and change log employment rates to employment growth rates. For right hand side variables, we include the lagged one period dependent variable and lagged one to lagged five period log home-ownership rates. We estimate the following models:

$$
\begin{aligned}
& \log \left(U E_{i, t}\right)=\alpha_{1} \log \left(U E_{i, t-1}\right)+\beta_{1} \log \left(H R_{i, t-k}\right)+\gamma_{1} C_{i, t}+\varepsilon_{i, t}^{1} \\
& \text { EMGRTH }_{i, t}=\alpha_{2} \text { EMGRTH }_{i, t-1}+\beta_{2} \log \left(H R_{i, t-k}\right)+\gamma_{2} C_{i, t}+\varepsilon_{i, t}^{2}
\end{aligned}
$$

For equation (1), $U E_{i, t}$ is the unemployment rate in state $\mathrm{i}$ in period t. We look at the relationship for 50 states and District of Columbia from 1988 to 2013. $U E_{i, t-1}$ is the unemployment rate in state $\mathrm{i}$ in period $\mathrm{t}-1 . \log \left(H R_{i, t-k}\right)$ is the $\log$ home-ownership rates in state $\mathrm{i}$ in period t-1 through t-5. $C_{i, t}$ is a vector of control variables in state $\mathrm{i}$ in period $\mathrm{t}$, including age, sex, education, marriage, race, and time and state fixed effects. They are the annual means for each state of each period. We have 15 education dummies and 2 race dummies. The education dummies are from less than $1^{\text {st }}$ grade to doctorate degree ${ }^{7}$. The race dummies are white, black and others. The control variables are from the CPS MORG data. The unemployment and employment data are from the U.S. Bureau of Labor Statistics. The home-ownership rates are

\footnotetext{
${ }^{7}$ The categories for the education dummies are: less than $1^{\text {st }}$ grade, $1^{\text {st }}-4^{\text {th }}$ grade, $5^{\text {th }}$ or $6^{\text {th }}, 7^{\text {th }}$ or $8^{\text {th }}, 9^{\text {th }}, 10^{\text {th }}, 11^{\text {th }}, 12^{\text {th }}$ grade NO DIPLOMA, high school graduate or diploma or GED, some college but no degree, associate degree-occupational/vocational, associate degree-academic program, bachelor's degree, master's degree, professional school, doctorate degree. This categorization is only for the data after 1992 so for the data before 1992 we matched another education variable in CPS MORG with this categorization.
} 
from the U.S. Bureau of Census. All data are downloaded from Federal Reserve Economic DataFRED - Federal Reserve Bank of St. Louis.

Because we have lagged dependent variables as the right hand side variables, we perform both OLS and GMM (Arellano-Bond estimation) estimations on equations (1) and (2). The results are in Tables 4 and 5. For the unemployment OLS result in column 1, the first, third, and fourth lag home-ownership effects are all negative but only the fifth, which is positive, is significant. Although none of the first four lags are significant, the fact that they are all negative implies to us that they can't be ignored. Consequently, we take the average magnitude of the five lags to determine the impact of the ownership rate on unemployment.

The GMM results in Table 5 are less ambiguous, in that only the first lag of the homeownership rate coefficient is negative. The average coefficient is 0.076 , meaning that for five years, when the home-ownership rate increases by 1 percent, the unemployment rate increases by 0.076 percent on average, a little less than the impact implied by the OLS model. Between 1984 and 2013, the U.S. national home-ownership rate increased by 0.38 percent. If the GMM model is correct, this implies that the unemployment rate is permanently higher by 0.029 percent as a result of the increase in owning.

Tables 6 and 7 report how ownership affects employment growth: the short answer is that it doesn't. Of the 20 coefficients on the impact of ownership on employment growth, only two are different from zero at the 95 percent level of confidence. The probability that this is random is 82 percent.

We graph an impulse response function of the dynamic impact of a change in ownership on unemployment. Figure 1 shows the impulse response of the log (unemployment rate). The 
dotted line is for the GMM result and the solid line is for the OLS. For the OLS line, we see that for a one unit increase of the log (home-ownership rate), the instant effect is negative, then the effect is positive and then balances back to zero. After 5 years, the effect goes to the maximum of 0.38. For the GMM result, the effect is only negative for the first lag period, and the maximum effect of 0.72 appears 5 years after the shock. After 17 years, the effect dies out for both OLS and GMM. The impulse response effect works through both the lagged home-ownership and unemployment coefficients. Unemployment inertia enlarges the small effect of the homeownership coefficients.

\section{B. Probability of unemployment for homeowners and renters in different homeowner concentration areas}

We next explore the effect of home-owning at the individual level. We use the annual PSID data from 1994 to 2011 for investigating the effects of owning on unemployment probabilities and wages. We use the monthly SIPP data from 1995 to 2013 for investigating the impact of owning on unemployment and employment spell lengths. We use both data sets to study the impact of tenure on mobility. The summary statistics for the PSID are in Table 8 . We have seven different categories for the variables. The first gives national averages based on census data. The remaining columns present summary statistics for different categories of individuals surveyed for the PSID. Data in the first column are from 2012; data in the others are averages of the sample period of 1994 to 2011. Data from the sample we use to study mobility are from 2001 to 2011.

Note from the summary statistics that the unemployment rates are lower for owner heads and "wives" than their counterpart renters. This likely reflects omitted variables. Renters have 
higher mobility rates than owners, again perhaps reflecting omitted variables. Renters also have lower wages. Renter household heads are far less likely to be married than owners, and are more likely to live in apartments and in large cities. For the renter and owner "wife" comparison, the conclusion is almost the same except that most of renter "wives" are married. Marriage is, of course, a strong predictor of ownership. ${ }^{8}$

Next, we test how the probability of unemployment is affected by being an owner or a renter and how the state level home-ownership rate affects unemployment probabilities. We use lagged one period explanatory variables to mitigate against reverse causation. We also include contemporaneous time fixed effects. We are concerned with two potential sources of endogeneity. First, owners might have unobserved characteristics that might make them more likely to be employed. Second, owners might have unobserved characteristics that might make them less mobile. We address endogeneity with our lagged control variables and by performing IV estimations. We choose two instruments for home-ownership: the state level home-ownership rate and the state level marginal tax rate $^{9}$. This state level home-ownership rate instrument is used by Munch (2007)'s study in Denmark, and Van Leuvensteijn (2004)'s study in the Netherlands. Coulson and Fisher (2009)'s study in the U.S. used marginal tax rate as an instrument. We try a variety of model specifications as one method for checking robustness. The specifications include OLS, logit, and panel data fixed and random effects.

The model we estimate is as follows:

$$
\operatorname{Pr}\left(U E_{j, i, t}\right)=\delta H R D_{i, t-1}+\phi O W N_{j, i, t-1}+\theta^{\prime} X_{j, i, t-1}+v_{j, i, t}^{1}
$$

\footnotetext{
${ }^{8}$ A glance at Table 2 shows that Latinos and Asians are underrepresented in the core PSID sample.

${ }^{9}$ The IV regression results are quite similar for the state home-ownership rates and marginal tax rates so we only report the IV estimation result with marginal tax rates as instrument.
} 
$\operatorname{Pr}\left(U E_{j, i, t}\right)$ is the probability of unemployment for individual $\mathrm{j}$ in state $\mathrm{i}$ in period $\mathrm{t}$. $H R D_{i, t-1}$ are dummies for whether the state home-ownership rate is: less than $65 \% ; 65 \%$ to $70 \%$; or higher than $70 \% . O W N_{j, i, t-1}$ is the dummy of whether the individual $\mathrm{j}$ in state $\mathrm{i}$ in period $\mathrm{t}-1$ is a homeowner or not. $X_{j, i, t-1}$ is a set of control variables for individual $\mathrm{j}$ in state $\mathrm{i}$ in period $\mathrm{t}-1$, including marriage, number of children, sex, race, education, the "wife's" wage larger than zero dummy, age, state and time fixed effect dummies. The data period is from 1994 to 2011. Altogether we have 49,333 observations for estimation. We first run OLS, logit, random effects and fixed effects on this model. Then we run two stage least squares for IV estimation.

The results of different specifications are quite consistent, as shown in Table 9. Homeowners are less likely to be unemployed under the OLS, logit, RE and FE models. The coefficients are all marginal effects and they are all negative and significant, except for the FE model. The fact that the FE coefficient is not different from zero could mean that it is unobservables that are driving the OLS, logit and RE results, or it could just mean that we are using up a large number of degrees of freedom. We will revisit this issue by using IV regressions. The standard errors are robust and clustered at the individual level, yielding 11,291 clusters. The RE model has a marginal effect of -0.606 , and this might serve as an upper bound for the effect of being an owner. For the OLS, logit and RE models, the effect of the state home-ownership rate is quite small with coefficients close to zero, ranging from -0.001 and -0.078 and are not significant at customary levels of confidence. For the fixed effects regressions, the coefficients are slightly positive but not effectively or statistically different from zero.

We next perform IV estimations to deal with endogeneity. We choose state marginal tax rates as our instrument. Table 10 provides our first stage home-ownership regression results. We 
can see that the instrument is significant and not weak. Married people, people with children and males are more likely to be homeowners. African Americans, Asians and Latinos are less likely to be homeowners than whites. More educated, older people and those whose "wives" work are more likely to own homes.

We present the IV regression results in column (5) of Table 9. The results confirm the FE results: the impact of home-owning on unemployment is, after controlling for unobservables, not materially different from zero.

As for state home-ownership rate effects in the IV results, we find that when compared with OLS, logit and fixed effects regressions, the coefficient magnitudes are smaller in absolute value. Nevertheless, the coefficients remain small relative to their standard errors. We can say with some confidence, however, that we find no evidence that state home-ownership rates harm individual employment status.

For the other variables, the results are consistent across all the model specifications. Married couples, better educated people, and heads who have working "wives" are less likely to be unemployed. Males and the family heads with children are more likely to be unemployed. This might imply that for the families with children, the heads may allocate less time for work and more for families. When compared to whites, African Americans and Latinos are more likely to be unemployed and Asians are less likely to be unemployed. Older heads are less likely to be unemployed than younger heads. The results for "wives" (Table 9.1) resemble the results for heads.

\section{Hazard rates of unemployment and employment for homeowners and renters}


So far we have presented results showing that owners are no more likely to be unemployed than renters. We now look at how long owners remain employed and, conditional on being unemployed, how long it takes them to move out of unemployment. We use the proportional hazards (PH) model below:

$$
h_{j, i}(t)=h_{0}(t) \exp \left(\eta H R D_{i, t-1}+\lambda O W N_{j, i, t-1}+x_{j, i, t} \kappa\right)
$$

$h_{j, i}(t)$ is the hazard rate for individual $\mathrm{j}$ in state $\mathrm{i}$ in period $\mathrm{t}$. We consider both the hazard rate from unemployment to employment and the hazard rate from employment to unemployment. The time unit is month. The right hand side variables are identical to those in the unemployment probability regressions, except that we also control for city size, which proxies for depth of the labor market. We did not use the PSID data because people in it are surveyed biannually between 2001 and 2011, which makes inferring unemployment duration unreliable. We therefore use SIPP data for the analysis. We use the 2008 panel covering monthly data from September 2008 to April 2013. We also test the relationship with 1996, 2001 and 2004 panels covering 1995 to 2006 in Appendix 2. The results are quite similar with the 2008 panel.

When we estimate the hazard rate for leaving unemployment, we follow the people who were unemployed after September 2008. For some individuals, we have multiple unemployment spells within the time period of the data. We perform parametric Weibull regressions and adjust for both left truncation and right censoring problems. Altogether, we have 1,715,500 observations, made up of 58,327 individuals, of whom 14,510 had an unemployment spell of one month or longer ${ }^{10}$ during the study period. The period contained 18,404 unemployment transitions (from employment to unemployment). Many individuals had multiple transitions. For

\footnotetext{
${ }^{10}$ For the definition of being unemployed, we categorize the ones who are not working the full month as unemployed.
} 
the hazard estimation from employment to unemployment, we also have 1,715,500 observations with 58,327 individuals. Among the employed were 69,389 employment transitions.

Tables 11 and 12 show the results of the unemployment and employment hazard rate estimations respectively. We perform proportional hazard $(\mathrm{PH})$ rate estimation with the Weibull distribution for the base line hazard. We also perform the conditional regressions with the duration of the time that the person has already been unemployed or employed as one of the regressors with OLS and logit specifications. Tables 11.1 and 12.1 report specifications looking at the same questions from different angles, using the time length of unemployment and employment as dependent variables, respectively. For Tables 11.1 and 12.1, we include the OLS and the accelerated failure-time (AFT) specifications ${ }^{11}$, as well as their IV counterparts.

For Table 11, coefficients in excess of one reflect that an increase in the right hand side variable increases the probability of exiting unemployment. For Table 11.1, negative coefficients indicate that an increase in the right hand side variable decreases the unemployment spell length. For Table 12, coefficients less than one reflect that an increase in the right hand side variable decreases the probability of exiting employment. For Table 12.1, positive coefficients indicate that an increase in the right hand side variable increases the employment spell length. We will discuss these results together because they are the two sides of the employment/unemployment story.

Table 11's first column presents the parametric results. It shows that owners are only slightly more likely to get out of unemployment than renters. The second column is the $\mathrm{IV}^{12}$ estimation with marginal tax rates as the instrument. The coefficient for owners is again slightly

\footnotetext{
${ }^{11}$ The accelerated time model is the same as the hazard rate model and it is just a different form of the hazard rate model. It uses the time length as the dependent variables so that it can be compared with the OLS in Tables 9.1 and 10.1.
} 
larger than one. For OLS in the third column, the effect is also close to one. Logit results presented in the fourth column provide the largest positive effect, but for the IV estimation of logit, the effect goes away.

As a robustness check, in Table 11.1 we also perform regressions on the unemployment durations with OLS and the AFT form of the parametric Weibull regression, and compare the results to those in Table 11. We can see that for the first two columns, owners have significantly shorter unemployment spells. We also use marginal tax rate for instruments in columns 3 and 4 , and the coefficients are still negative and the magnitudes don't change much from the first two columns. Nothing in Tables 11 and 11.1 implies that unemployed owners are at a disadvantage to renters.

Next we reverse field and look at the hazard rate from employment to unemployment. Tables 12 and 12.1 show the results. In Table 12, coefficients smaller than one mean that an increase in the right hand side variable decreases the probability of leaving employment. In Table 12.1, positive coefficients indicate that an increase in the right hand side variable increases the length of employment spells. Table 12 shows owners are a little more likely to stay employed, although relative to the OLS results, the IV results are attenuated. In Table 12.1 all the coefficients are positive and significant. Overall, our results show that owners are both slightly more likely to get out of unemployment, and slightly more likely to stay employed. Perhaps owners are more stable and committed; perhaps they are disciplined by having mortgages to pay back; perhaps they are attached to their neighborhood. That said, we should also recall that all differences between owners and renters are modest. The results are quite similar for the panels of 1996, 2001 and 2004 (Appendix 2). 
In Table 11, the individuals who live in higher home-ownership rate states are more likely to exit unemployment. Table 12 shows that people in high home-ownership rate states are more likely to remain employed. Tables 11 and 12 also show that married people are more likely to stay employed and exit unemployment. Surprisingly, city size doesn't seem to matter to the length of unemployment or employment spells. Having children might render people less likely to exit unemployment and more likely to exit employment. Males are more likely to exit unemployment and remain employed a little longer. Compared to whites, African Americans and Latinos are less likely to exit unemployment, but African Americans and Asians are more likely to remain employed. Better educated people and older people have better employment outcomes, including shorter unemployment spells and longer employment durations.

\section{Moving probabilities for homeowners and renters}

Home-ownership might reduce mobility owing to the high transaction costs associated with purchasing and selling a house. While we have shown that unemployment duration is not elongated by home-owning, we decided that testing whether homeowners' mobility is reduced was nevertheless a worthwhile exercise.

For estimating the impact of tenure on mobility, we use the PSID dataset from 2001 to 2011. PSID participants are surveyed every two years, and are asked what they did the previous year. The sample size for estimation is 37,582 . We re-categorize the nine categories ${ }^{13}$ of moving in the data into the four major categories listed below (Table 13):

\footnotetext{
13 Move Categories: 0 is not moving; 1 is purposive productive reasons: to take another job; transfer; stopped going to school; 2 is to get nearer to work; 3 is purposive consumptive reasons--expansion of housing: more space; more rent; better place; 4 is purposive consumptive reasons--contraction of housing: less space; less rent; 5 is purposive consumptive--other house-related: want to own home; got married; 6 is purposive consumptive--neighborhood-related: better neighborhood; go to school; to be closer to friends and/or relatives; 7 is the response to outside events (involuntary reasons): housing unit coming down; being
} 
Table 13: Categories of MOVE in PSID

\begin{tabular}{l|cc}
\hline \hline MOVE & Renters & Owners \\
\hline 0. Not Move & $47.45 \%$ & $87.29 \%$ \\
1. Work related move & $5.80 \%$ & $1.31 \%$ \\
2. House consumption move & $28.91 \%$ & $6.51 \%$ \\
3. Involuntary move & $17.84 \%$ & $4.89 \%$ \\
\hline
\end{tabular}

From the table above, we can see that owners have lower mobility rates than renters. Both renters and owners move most often to change their consumption of housing, in fact, both groups move to change consumption about 5 times as often as they move for work related reasons. Owners move involuntarily much less often than renters. We might postulate that people first find jobs and then buy or rent houses around their job locations. After this, they might move for a larger or smaller house, but will far less often change location because of a job switch. SIPP data give us different insights about moves than the PSID. SIPP mobility data are summarized in the Table 13.1 below.

Table 13.1: Categories of MOVE in SIPP

\begin{tabular}{llll}
\hline \hline Variables & Whole Sample & Owners & Renters \\
\hline 0. Non-mover & $97.54 \%$ & $98.98 \%$ & $94.14 \%$ \\
$\begin{array}{l}\text { 1 .Moved, same county } \\
\begin{array}{l}\text { 2.Moved, different county } \\
\text { within same state }\end{array}\end{array}$ & $1.64 \%$ & $0.67 \%$ & $3.91 \%$ \\
3 .Moved, different state & $0.33 \%$ & $0.23 \%$ & $1.12 \%$ \\
\hline
\end{tabular}

SIPP data tell us the distance people moved: within county, within state, or across states. State movers, which likely involve job change or job status change, are rare.

evicted; armed services, etc.; health reasons; divorce; retiring because of health; 8 is ambiguous or mixed reasons: to save money; all my old neighbors moved away; retiring (NA why) 
We use a multinomial logit model to test whether people's mobility is reduced by homeowning. Identifying the impact of housing tenure on mobility is confounded by the fact that people who choose to be immobile will also be more likely to own a house. We therefore use IV estimation with marginal tax rate again as the instrument. Table 14 shows the results from PSID data. The base category is not move and the coefficient is the odds ratio of moving for work, house consumption and involuntary reasons compared to not move, from the impact of the right hand side variables. So if the coefficient is in excess of one it means increasing the right hand side variables increases the probability of moving. The standard errors are clustered at the individual level.

For owners, the first three panels show that they are less likely to move for any reason: work, consumption and expulsion. However, after correcting for endogeneity, the IV estimates in (4) show that owners are not less likely to move than renters for job reasons (the coefficients are not statistically different from one). Combining the employment spell results and the mobility results, we find that homeowners may be more committed to their jobs, but they are not less likely to move when necessary for job reasons. Intrinsic immobility, rather than transaction costs, seems to explain differences in observed mobility between owners and renters.

We also estimated the multinomial logit model using the SIPP data. The result is in Table 14.1. We again use the marginal tax rate as our instrument. The first three columns using uninstrumented logit show that owners are less likely to move, but in the IV result in the last three columns, owners are more likely to move to different counties and states, indicating that they are more likely to move for job reasons. 
In the SIPP data, in the non-IV regressions, states with higher home-ownership rates have more interstate movers, but the effect disappears in the IV specification. We present results for "wives" in Table 15. The first three columns show that "wives" are, in general, less likely to move. After making the IV correction, we find that the "wife" is also less likely to move for work reasons. This indicates that "wives" might be more likely to settle for a less desirable job environment.

\section{E. Wages}

In this section, we explore the impact of ownership on wages. If home-ownership makes people less likely to pursue the best job match, owners might settle for lower wages. Tables 16 and 17 show the wage results for family heads and "wives" respectively. We again use the marginal tax rate as the instrument for home-ownership. For heads, the OLS model shows that owners have higher wages, but after the IV correction, the effect goes to zero. Using fixed effects also shows that owning has no negative impact on wages. In higher home-ownership states, wages are a little higher for both renters and owners. Not surprisingly, married people, males, more educated and older people have higher wages. Households with children have slightly lower wages. African American, Latinos and Asians all have lower wages than whites.

For "wives" (Table 17), we find that married women have a lower wage; the presence of children drives down wages more for "wives" than heads. African American and Asian "wives" have higher wages than whites. "Wives" older than 55 have lower wages than "wives" younger than 25 .

\section{F. Different types of homeowners}


So far, we have shown that at the aggregate level, the home-ownership rate has no significant effect on employment growth. At the individual level, owners are not more likely to be unemployed than renters. For unemployment spell length, owners and renters don't differ much, but owners have longer employment spells. And owners are not less likely to move than renters for job reasons and are more likely to move to other states. We find no significant difference in owners and renters' wages. In total, given our endogeneity corrections, we have reason to believe that owners have more employment stability than renters and seem to be more able to move. The question is why.

Some possible explanations are:

(1) Most owners have mortgages, needing to meet a debt-service payment that motivates them to remain in their current employment status (Goss and Phillips, 1997; Flatau et al., 2003).

(2) Some homeowners have negative equity. A number of papers have argued that negative equity has an impact on mobility (Stein, 1995; Chan, 2001; Oswald, 2013).

(3) Homeowners accumulate wealth through owning, this wealth may allow owners to better handle life uncertainties or difficulties. Specifically, with wealth come resources that can help with job search.

(4) Owners may have greater stakes in their communities. They are invested in their neighborhoods. They have emotional attachments to their houses, neighbors and communities. This motivates them to find employment quickly and locally. One way to test this might be to examine the effect of years of 
being homeowners and the effect of house improvements on employment outcomes.

To test those four points, we perform regressions for homeowners only. The table below lists the independent and dependent variables we use:

Table 18: The regression variables for investigating homeowner characteristic effects on employment outcomes

\begin{tabular}{l|l}
\hline Dependent variables & Independent variables \\
\hline $\begin{array}{l}\text { 1. Probability of } \\
\text { unemployment }\end{array}$ & $\begin{array}{l}\text { Whether owners have a mortgage } \\
\text { Negative equity level and its dummy of whether having negative equity } \\
\text { Home value } \\
\text { Positive equity levels and its dummy } \\
\text { Wealth levels with housing and without housing and their dummies } \\
\text { 2. Employment and } \\
\text { unemployment } \\
\text { hazard rates }\end{array}$ \\
$\begin{array}{l}\text { 3. Mobility } \\
\text { Years of being homeowners } \\
\text { Control variables including marriage, sex, city size, state home-ownership rates, } \\
\text { children number, race, education, age, time and state fixed effects }\end{array}$ \\
$\begin{array}{l}\text { Note: The independent variables are in their lagged one period values and the levels are all in their log values. And } \\
\text { independent variables are the same for the three dependent variables. We run regressions for the whole period, } \\
\text { before, and during the financial crisis. }\end{array}$
\end{tabular}

We therefore estimate:

$\operatorname{Pr}\left(U E_{j, i, t} \mid\right.$ owner $)=\mu_{1} X_{j, i, t}+v_{1} C_{j, i, t}+$ error $_{j, i, t}$

$h_{j, i}(t \mid$ owner $)=\mu_{2} X_{j, i, t-1}+v_{2} C_{j, i, t-1}+$ error $_{j, i, t-1}$

$\operatorname{Pr}\left(\right.$ move $_{j, i, t} \mid$ owner $)=\mu_{3} X_{j, i, t-1}+v_{3} C_{j, i, t-1}+$ error $_{j, i, t}$

Where $X_{j, i, t}=$ Mortgage $_{j, i, t}$, NegativeEquity $_{j, i, t}$, Wealth $_{j, i, t}$, Attachment $_{j, i, t}$ 
Where $\mathrm{j}$ is the individual, $\mathrm{i}$ is the state and $\mathrm{t}$ is the period. Wealth includes positive equity, house value, and wealth with housing and without housing; attachment includes years of being homeowners and the housing improvements made.

\section{Unemployment probabilities}

First, we present the unemployment probability results from logit regressions. Table 19 shows the mortgage effect on owners' unemployment probabilities. The existence of a mortgage creates an unobservables problem: these who choose to have mortgages may behave differently in the job markets than those that do not. So we again use IV technique. We use the state level mortgage ratio and the marginal tax rate as the instruments ${ }^{14}$.

In non-instrumented specifications, owners with mortgages are less likely to be unemployed for the whole period and also for the periods before and during the financial crisis [(1), (3) and (5) of Table 19]. But when we use an instrument, the impact disappears. Perhaps a selection criterion for mortgages via underwriting is driving the likelihood of continuing employment.

With negative equity (Table 20), we again face an endogeneity issue, because those that recklessly take too much debt might be more likely to be unemployed and more likely to have negative equity at the same time ${ }^{15}$. The independent variable is the $\log$ of the absolute value of negative equity. The instrument we use is the state level negative equity ratio ${ }^{16}$. In this case, we get no effect, regardless of specifications. Time and state fixed effects may be soaking up differences in negative equity. Table 21 shows the effects of the other independent variables.

\footnotetext{
${ }^{14}$ We only report the IV result using marginal tax rate as instrument because the IV result is quite similar using the mortgage ratio.

15 Demyanyk et al. using different data find no evidence of a lock in effect.

${ }^{16}$ We constructed this instrument from the PSID data within the owners who have mortgages by state.
} 
First we look at various wealth variables. The results show that there are significant and negative effects from the owners' wealth accumulation on their unemployment probability. In particular, housing wealth has a profound impact on the probability of unemployment. Note that we have established that when instrumented, mortgage choice, the mechanism by which people choose to have equity, does not have an impact on unemployment. Thus, having wealth appears to be a channel for reducing unemployment probability. Variables relating to attachment to community have no impact on unemployment probability.

\section{Employment spell}

We analyze the determinants of employment and unemployment spells similarly to how we analyzed the determinants of employment probability. We are attempting to determine why owners have longer employment spells than renters. We are interested in differences in the effects of mortgages and wealth before and after the financial crisis. We use the 2004 and 2008 panels of SIPP to represent the periods before and during/after the crisis. Tables 22 and 22.1 show the results. Columns (1) in Table 22 and 22.1 show that before the crisis, owners with mortgages were less likely to leave their existing employment conditions, whether they are unemployed or employed. The effects are small but significant. Columns (3) in both tables show that after the crisis, owners with mortgages continued to be less likely to leave their existing labor market conditions, but the effects are not significant.

When instrumented $^{17}$, in columns (2) of both tables, people still were less likely to leave their current conditions before the crisis. But after the crisis in (4), people seemed to be more likely to exit their current labor market conditions, though the impacts are not significant. This result might suggest that mortgages might have made owners less prone to move. The effect is

\footnotetext{
${ }^{17}$ The estimation uses marginal tax rate as the instrument.
} 
larger on people who are employed. This helps explain why owners have longer employment spells but not longer unemployment spells than renters. Wealth also seems to motivate people to stay put.

The negative equity dummy effect on employment and unemployment spells is presented in Table 23. We use PSID data from 2003 to 2011. The PSID doesn't have consecutive years of employment records, so we run regressions for each year individually on 2003, 2005, 2007, 2009 and 2011. The impact of negative equity doesn't change before or after the crisis. The owners with negative equity are less likely to leave employment in the non-instrumented results, but are more likely to leave in the IV results. Unemployed owners with negative equity are more likely to exit unemployment in both specifications. It might indicate that the owners with negative equity may be motivated to default: the net cost of default could well be less than the benefit of finding a new job.

Table 24 shows the other variables' effects, based on 2011 data. All measures of wealth other than house value predict longer employment tenure. None of the attachment to community variables explains employment tenure. The unemployment spells results, in Table 24.1, show that wealth variables, excluding log house value have a significant but small impact on length of unemployment: wealthier people take slightly more time to exit unemployment. Attachment variables never predict a lower exit from unemployment. Taken together, the empirical results show that wealth affects owners' employment spells more than they affect unemployment spells. This at least partially corroborates the view that the mortgages and wealth accumulation are the reasons for why homeowners have longer employment spells.

\section{Mobility}


We have already shown that homeowners are not less likely to move than renters. In this section, we want to show how the home-owning characteristics might affect owners' mobility. We use PSID data from 2001 to 2011 to investigate the effect on people's job-related mobility. Table 25 shows the mortgage effects. The standard errors in those regressions are too large to identify a mortgage effect. The same is true in the negative equity regressions (Table 26).

Table 27 shows that owners with positive equity are less mobile. The other wealth variables are either marginally significant or not significant at all. Length of housing tenure predicts mobility: those who live in a house for a long time are less likely to move.

We finally use the 2001, 2004 and 2008 panels of the SIPP to test whether owners with mortgages move to other states. The results are in Table 28. The results are mixed: owners with mortgages were more likely to move to other states and counties in 2008; we can't identify a relationship between having a mortgage and interstate moves for 2001 and 2004 . We can say that mortgages did not lock owners in during the financial crisis.

Overall, therefore, we find no systematic evidence that ownership produces immobility; this explains why owners are no more likely to remain unemployed than renters.

\section{Conclusion}

In this article, we investigate whether home-ownership affects the probability of being employed, the durations of employment and unemployment, and mobility. We wish to test the effects at both the individual and aggregate levels.

Owner housing is both a consumer good and an investment. The investment aspects of owning might affect people's employment. The direction of the impact is uncertain. The wealth 
embedded in owner housing might provide resources that allow people to overcome the obstacles to moving, such as moving costs. On the other hand, transaction costs related to owner housing might inhibit moves. These costs might "trap" people in their jobs; we thus might see people stay in jobs longer than they should, or accept jobs with a suboptimal wage. Identifying the impact of owning on mobility is, however, difficult, because individuals less prone to moving are more likely to become owners in the first place.

Finally, owners whose houses have lost value might be more likely to stay in place because (1) they anchor on purchase prices and are averse to losses and (2) because they might have negative equity.

In another line of reasoning, Oswald and Blancheflower (2013) argue that ownership produces NIMBYism, which in turn stunts economic development and employment growth.

Overall, arguments about the impact of ownership, both at the individual and aggregate levels, appear to be tempests in a teapot. Empirically, we find that ownership rate does not affect employment growth; and might lead to slight unemployment increases. We find that owners are not more likely to be unemployed, have unemployment spells that are not longer than renters, and that their wages are not lower. Owners' employment spells are slightly longer; they are also more likely to make interstate moves. These results indicate that owning does not lock people in and their employment outcomes are not negatively influenced. In fact, the individual level homeowning effect might be positive. As for how different aspects of owning affect employment, we find:

- Among presence of mortgage, negative equity, attachment to community and wealth, only wealth plays a profound role on unemployment probabilities. 
- We do, however, find that presence of mortgages encourages people to stay put and not change their existing employment status. Negative equity, on the other hand, motivates people to default and leave their current employment status.

- Wealth plays a large part in elongating peoples' employment durations, but a small part in elongating their unemployment durations.

- Attachment to communities is irrelevant to people's employment spells, but homeowners with tenure in excess of 2 years are more likely to leave unemployment.

- The presence of a mortgage or negative equity does not affect the probability of a job-related move. Nevertheless, people with mortgages became more likely to move to other states after the crisis.

In the end, it is not home-owning, but people's intrinsic characteristics that drive employment outcomes. People seem to make appropriate strategic and economic moves, regardless of whether they are owners or renters. 


\section{References:}

Aaronson, Daniel, and Jonathan Davis. (2011). How much has house lock affected labour mobility and the unemployment rate?. Chicago Fed Letter, Number 290. Retrieved from https://www.chicagofed.org/publications/chicago-fed-letter/2011/september-290

Blanchflower, D., \& Oswald, A. (2013). Does High Home-Ownership Impair the Labor Market? (Working Paper No. 19079). Retrieved from National Bureau of Economic Research website: http://www.nber.org/papers/w19079

Burnley, I., Murphy, P., \& Jenner, A. (1997). Selecting Suburbia: Residential Relocation to Outer Sydney. Urban Studies, 34(7), 1109-1127. doi:10.1080/0042098975754

Case, K. (1992). The Real Estate Cycle and the Economy: Consequences of the Massachusetts Boom of 1984-87. Urban Stud., 29(2), 171-183. doi:10.1080/00420989220080251

Case, K., Quigley, J., \& Shiller, R. (2005). Comparing Wealth Effects: The Stock Market versus the Housing Market. Advances In Macroeconomics, 5(1). doi:10.2202/1534-6013.1235

Chan, S. (2001). Spatial Lock-in: Do Falling House Prices Constrain Residential Mobility?. Journal Of Urban Economics, 49(3), 567-586. doi:10.1006/juec.2000.2205

Coulson, N., \& Fisher, L. (2002). Tenure Choice and Labour Market Outcomes. Housing Studies,17(1), 35-49. doi:10.1080/02673030120105875

Coulson, N., \& Fisher, L. (2009). Housing tenure and labor market impacts: The search goes on. Journal Of Urban Economics, 65(3), 252-264. doi:10.1016/j.jue.2008.12.003

Donovan, C., \& Schnure, C. (2011). Locked in the House: Do Underwater Mortgages Reduce Labor Market Mobility?. SSRN Journal. doi:10.2139/ssrn.1856073

Elliott, J. (1980). Wealth and Wealth Proxies in a Permanent Income Model. The Quarterly Journal Of Economics, 95(3), 509. doi:10.2307/1885091

Engelhardt, Gary V. and Christopher J. Mayer. (1994). Gifts for Home Purchase and Housing 
Market Behavior. New England Economic Review, 47-58.

Engelhardt, G. (1996). House prices and home owner saving behavior. Regional Science And Urban Economics, 26(3-4), 313-336. doi:10.1016/0166-0462(95)02118-3

Engelhardt, G. (2003). Nominal Loss Aversion, Housing Equity Constraints, and Household Mobility: Evidence from the United States. Journal Of Urban Economics, 53(1), 171-195. doi:10.2139/ssrn.1808954

Estevão, M., \& Tsounta, E. (2011). Has the Great Recession Raised U.S. Structural Unemployment?. IMF Working Papers, 11(105), 1. doi:10.5089/9781455260409.001

Evans, G., Wells, N., \& Moch, A. (2003). Housing and Mental Health: A Review of the Evidence and a Methodological and Conceptual Critique. Journal Of Social Issues, 59(3), 475-500. doi:10.1111/1540-4560.00074

Farber, H.S. (1999). Mobility and stability: the dynamics of job change in labor markets. In: Ashenfelter, O.C., Card, D. (Eds.). Handbook of Labor Economics, vol. 3B Elsevier, Amsterdam, The Netherlands, pp. 2439-2483.

Ferreira, F. (2010).You Can Take it With You: Proposition 13 Tax Benefits, Residential Mobility, and Willingness to Pay for Housing Amenities. Journal Of Urban Economics,94(3), 661-673.

Ferreira, Fernando, Joseph Gyourko and Joseph Tracy. (2010). Housing Busts and Household Mobility. Journal of Urban Economics, 68(1), 34-45.

Fischel, W. (2004). An Economic History of Zoning and a Cure for its Exclusionary Effects. Urban Studies, 41( 2), 317-340.

Flatau, P., Forbes, M., Hendershott, P., Wood, G. (2003). Homeownership and unemployment: The roles of leverage and public housing (Working Paper No. 10021). Retrieved from 
National Bureau of Economic Research website: http://www.nber.org/papers/w10021

Genesove, David, Mayer, Christopher. (1997). Equity and time to sale in the real estate market. American Economic Review. 87 (3), 255-269.

Genesove, David, Mayer, Christopher. (2001). Loss-aversion and seller behavior: evidence from the housing market. Quarterly Journal of Economics, 116 (4), 1233-1260.

Goss, E., Phillips, J., Summer. ( 1997). The impact of homeownership on the duration of unemployment. The Review of Regional Studies, 27 (1), 9-27.

Green, R., \& White, M. (1997). Measuring the Benefits of Homeowning: Effects on Children. Journal Of Urban Economics, 41(3), 441-461. doi:10.1006/juec.1996.2010

Green, R., \& Hendershott, P. (2001). Home-ownership and Unemployment in the US. Urban Stud., 38(9), 1509-1520. doi:10.1080/00420980120076777

Haurin, D., \& Gill, H. (2002). The Impact of Transaction Costs and the Expected Length of Stay on Homeownership. Journal Of Urban Economics, 51(3), 563-584. doi:10.1006/juec.2001.2258

Kain, J. (1968). Housing Segregation, Negro Employment, and Metropolitan Decentralization. The Quarterly Journal Of Economics, 82(2), 175. doi:10.2307/1885893

Kane, T. (1994). College Entry by Blacks since 1970: The Role of College Costs, Family Background, and the Returns to Education. Journal Of Political Economy, 102(5), 878. doi:10.1086/261958

Laamanen, Jani-Petri. (2013). Home-ownership and the Labour Market: Evidence from Rental Housing Market Deregulation. MPRA Paper, No. 55256. Retrieved from http://mpra.ub.uni-muenchen.de/55256/

Mills, E. (1987). Has the United States Overinvested in Housing?. Real Estate Economics, 15(1), 
601-616. doi:10.1111/1540-6229.00406

Mumford, K., \& Schultz K. (2009). The Effect of Underwater Mortgages on Unemployment. Retrieved from http://www.krannert.purdue.edu/faculty/kjmumfor/papers/Underwater_and_Unemployed pdf

Munch, J., Rosholm, M., \& Svarer, M. (2006). Are Homeowners Really More Unemployed?. Economic Journal, 116(514), 991-1013. doi:10.1111/j.1468-0297.2006.01120

Munch, J., Rosholm, M., \& Svarer, M. (2007). Home Ownership, Job Duration, and Wages. Journal Of Urban Economics, 63(1), 130-145.doi:10.2139/ssrn.1147065

Nickell, S. (1998). Unemployment: Questions and Some Answers. Economic Journal, 108(448), 802-816. doi:10.1111/1468-0297.00316

Oswald, Andrew J. (1996). A conjecture on the explanation for high unemployment in the industrialized nations: part 1.Working Paper. Coventry: University of Warwick, Department of Economics. Warwick economic research papers (No.475). Retrieved from http://wrap.warwick.ac.uk/1664/

Oswald, A. (1997). Thoughts on NAIRU (correspondence). Journal of Economic Perspectives, 11(1),pp. 227-228.

Oswald, A. (1999). The Housing Market and Europe's Unemployment: A Non-technical Paper. Working paper, University of Warwick. Retrieved from http://www.andrewoswald.com/docs/homesnt.pdf

Quigley, J. (1987). Interest Rate Variations, Mortgage Prepayments and Household Mobility. The Review Of Economics And Statistics, 69(4), 636. doi:10.2307/1935958

Schulhofer-Wohl, Sam. (2011). Negative Equity Does Not Reduce Homeowners' Mobility 
(Working Paper No. 16701). Retrieved from National Bureau of Economic Research website: http://www.nber.org/papers/w16701

Shiller, R., \& Case K. (1988). The Behavior of Home Buyers in Boom and Post-Boom Markets. New England Economic Review, pp. 29-46.

Stein, J. (1995). Prices and Trading Volume in the Housing Market: A Model with DownPayment Effects. The Quarterly Journal Of Economics, 110(2), 379-406. doi:10.2307/2118444

van Leuvensteijn, M., \& Koning, P. (2004). The effect of home-ownership on labor mobility in the Netherlands. Journal Of Urban Economics, 55(3), 580-596. doi:10.1016/j.jue.2003.12.001

Voith, Richard. (1999). Does the federal tax treatment of housing affect the pattern of metropolitan development?. Business Review - Federal Reserve Bank of Philadelphia, March, 3-16.

Wen, Y. (2001). Residential Investment and Economic Growth. Annals Of Economics And Finance, 2, 437-444. 
Table 1: Literature summary

\begin{tabular}{|c|c|c|c|c|c|c|c|c|c|c|c|}
\hline Author & $\begin{array}{l}\text { Aggregate (home- } \\
\text { ownership rates and } \\
\text { unemployment } \\
\text { rates) }\end{array}$ & $\begin{array}{l}\text { Less likely } \\
\text { to be } \\
\text { unemployed }\end{array}$ & $\begin{array}{l}\text { More likely } \\
\text { to be } \\
\text { unemployed }\end{array}$ & $\begin{array}{l}\text { Shorter } \\
\text { unemployment } \\
\text { spells }\end{array}$ & $\begin{array}{l}\text { Longer } \\
\text { unemployment } \\
\text { spells }\end{array}$ & $\begin{array}{l}\text { Higher } \\
\text { wages }\end{array}$ & $\begin{array}{l}\text { Lower } \\
\text { wages }\end{array}$ & Externality & $\begin{array}{l}\text { Endogeneity } \\
\text { correction } \\
\text { method }\end{array}$ & Country & Data \\
\hline Oswald 1996 & + & & & & & & & & no correction & US and EU & \\
\hline $\begin{array}{l}\text { Goss and Phillips } \\
1997\end{array}$ & & & & yes & & & & & $\begin{array}{l}\text { Heckman two } \\
\text { step }\end{array}$ & US & 1986 PSID \\
\hline Nickell 1998 & + & & & & & & & & no correction & $\begin{array}{l}\text { OECD } \\
\text { countries }\end{array}$ & \\
\hline Green 2000 & $\begin{array}{l}+ \text { for the middle } \\
\text { aged }\end{array}$ & & & & & & & & no correction & US & $\begin{array}{l}\text { Statistical } \\
\text { abstract of the } \\
\text { US }\end{array}$ \\
\hline Green 2001 & & & & & yes & & & & $\begin{array}{l}\text { Heckman two } \\
\text { step }\end{array}$ & US & $\begin{array}{l}\text { PSID (1986- } \\
1992)\end{array}$ \\
\hline $\begin{array}{l}\text { Coulson and Fisher } \\
2001\end{array}$ & & yes & & yes & & yes & & & no correction & US & $\begin{array}{l}\text { CPS March and } \\
\text { PSID (1992 } \\
\text { wave) }\end{array}$ \\
\hline $\begin{array}{l}\text { Coulson and Fisher } \\
2009\end{array}$ & - & yes & & & & & yes & yes & IV & US & $\begin{array}{l}1990 \text { CPS } \\
\text { Supplement }\end{array}$ \\
\hline Leuvensteijn 2004 & & yes & & & & & & & $\begin{array}{l}\text { simultaneous } \\
\text { equations }\end{array}$ & Netherland & \\
\hline Munch 2006 & & & & yes & & & no & & $\begin{array}{l}\text { simultaneous } \\
\text { equations }\end{array}$ & Denmark & individual level \\
\hline Munch 2007 & & yes & & & & yes & & & $\begin{array}{l}\text { simultaneous } \\
\text { equations }\end{array}$ & Denmark & individual level \\
\hline Garcia 2002 & - & & & & & & & & $\begin{array}{l}\text { simultaneous } \\
\text { equations }\end{array}$ & Spain & individual level \\
\hline Laamanen 2013 & $\begin{array}{l}\text { + on unemployment } \\
\text { spells (micro-level) }\end{array}$ & yes & & & & & & $\begin{array}{l}\text { yes (through } \\
\text { job mismatch } \\
\text { and crowding } \\
\text { out } \\
\text { consumptions) }\end{array}$ & $\begin{array}{l}\text { natural } \\
\text { experiment } \\
\text { with IV }\end{array}$ & Finland & individual level \\
\hline
\end{tabular}


Table 4: OLS result on the relationship of unemployment rates and home-ownership rates

\begin{tabular}{|c|c|c|c|c|c|c|}
\hline \multirow[t]{2}{*}{ VARIABLES } & \multicolumn{6}{|c|}{ logun: OLS } \\
\hline & $1988-2013$ & 1984-2013 & $1985-2013$ & 1986-2013 & $1987-2013$ & $1988-2013$ \\
\hline \multirow{2}{*}{ logunlag1 } & $0.787 * * *$ & $0.841 * * *$ & $0.844 * * *$ & $0.833 * * *$ & $0.809 * * *$ & $0.785 * * *$ \\
\hline & $(0.0161)$ & $(0.0153)$ & $(0.0153)$ & $(0.0151)$ & $(0.0153)$ & $(0.0159)$ \\
\hline \multirow[t]{2}{*}{ loghomelag1 } & -0.147 & $0.230 * *$ & & & & \\
\hline & $(0.1410)$ & $(0.0905)$ & & & & \\
\hline \multirow[t]{2}{*}{ loghomelag2 } & 0.277 & & $0.334 * * *$ & & & \\
\hline & $(0.1820)$ & & $(0.0889)$ & & & \\
\hline \multirow[t]{2}{*}{ loghomelag3 } & -0.0226 & & & $0.293 * * *$ & & \\
\hline & $(0.1820)$ & & & $(0.0873)$ & & \\
\hline \multirow[t]{2}{*}{ loghomelag4 } & -0.0065 & & & & $0.302 * * *$ & \\
\hline & $(0.1770)$ & & & & $(0.0877)$ & \\
\hline \multirow[t]{2}{*}{ loghomelag5 } & $0.327 * *$ & & & & & $0.365 * * *$ \\
\hline & $(0.1310)$ & & & & & $(0.0881)$ \\
\hline Average effect & 0.086 & - & - & - & - & - \\
\hline Year dummies & 24 & 28 & 27 & 26 & 25 & 24 \\
\hline State dummies & 50 & 50 & 50 & 50 & 50 & 50 \\
\hline Other controls & 20 & 20 & 20 & 20 & 20 & 20 \\
\hline Observations & 1,275 & 1,479 & 1,428 & 1,377 & 1,326 & 1,275 \\
\hline R-squared & 0.944 & 0.937 & 0.938 & 0.941 & 0.942 & 0.944 \\
\hline
\end{tabular}

Note: The dependent variable is the log of the state level unemployment rates and the independent variables of interest are the lagged log of the state level home-ownership rates. Other controls include fifteen educational dummies, one sex dummy, two race dummies, one marriage dummy and age. Standard errors are clustered at the state level and are in parentheses. Significance level: $* * * \mathrm{p}<0.01,{ }^{*} \mathrm{p}<0.05,{ }^{*} \mathrm{p}<0.1$ 
Table 5: GMM result on the relationship of unemployment rates and home-ownership rates

\begin{tabular}{|c|c|c|c|c|c|c|}
\hline \multirow{2}{*}{ VARIABLES } & \multicolumn{6}{|c|}{ logun: GMM } \\
\hline & 1988-2013 & 1984-2013 & $1985-2013$ & 1986-2013 & 1987-2013 & $1988-2013$ \\
\hline logunlag1 & $0.679 * * *$ & $0.727 * * *$ & $0.736 * * *$ & $0.733 * * *$ & $0.708 * * *$ & $0.674 * * *$ \\
\hline & $(0.0274)$ & $(0.0253)$ & $(0.0256)$ & $(0.0240)$ & $(0.0240)$ & $(0.0263)$ \\
\hline loghomelag1 & $\begin{array}{l}-0.0203 \\
(0.1260)\end{array}$ & $\begin{array}{l}0.386 * * \\
(0.1550)\end{array}$ & & & & \\
\hline loghomelag2 & $\begin{array}{l}0.236 \\
(0.1540)\end{array}$ & & $\begin{array}{l}0.542 * * * \\
(0.1530)\end{array}$ & & & \\
\hline loghomelag3 & $\begin{array}{l}0.0771 \\
(0.1350)\end{array}$ & & & $\begin{array}{l}0.511 * * * \\
(0.1350)\end{array}$ & & \\
\hline loghomelag4 & $\begin{array}{l}0.0112 \\
(0.1600)\end{array}$ & & & & $\begin{array}{l}0.531 * * * \\
(0.1740)\end{array}$ & \\
\hline loghomelag5 & $\begin{array}{l}0.589 * * * \\
(0.1690)\end{array}$ & & & & & $\begin{array}{l}0.670 * * * \\
(0.1780)\end{array}$ \\
\hline Average effect & 0.076 & - & - & - & - & - \\
\hline Year dummies & 24 & 28 & 27 & 26 & 25 & 24 \\
\hline State dummies & 50 & 50 & 50 & 50 & 50 & 50 \\
\hline Other controls & 20 & 20 & 20 & 20 & 20 & 20 \\
\hline Observations & 1,224 & 1,428 & 1,377 & 1,326 & 1,275 & 1,224 \\
\hline
\end{tabular}

Note: The dependent variable is the log of the state level unemployment rates and the independent variables of interest are the lagged log of the state level home-ownership rates. Other controls include fifteen educational dummies, one sex dummy, two race dummies, one marriage dummy and age. Standard errors are clustered at the state level and are in parentheses. Significance level: $* * * p<0.01, * * \mathrm{p}<0.05, * \mathrm{p}<0.1$ 
Table 6: OLS result on the relationship of employment growth rates and home-ownership rates

\begin{tabular}{|c|c|c|c|c|c|c|}
\hline \multirow{2}{*}{ VARIABLES } & \multicolumn{6}{|c|}{ emgrowth: OLS } \\
\hline & 1988-2013 & 1984-2013 & $1985-2013$ & 1986-2013 & $1987-2013$ & 1988-2013 \\
\hline \multirow[t]{2}{*}{ emgrowthlag1 } & $0.632 * * *$ & $0.661 * * *$ & $0.657 * * *$ & $0.640 * * *$ & $0.588 * * *$ & $0.631 * * *$ \\
\hline & $(0.0216)$ & $(0.0196)$ & $(0.0199)$ & $(0.0192)$ & $(0.0199)$ & $(0.0216)$ \\
\hline \multirow[t]{2}{*}{ loghomelag1 } & -0.016 & $-0.0300 * * *$ & & & & \\
\hline & $(0.0152)$ & $(0.0102)$ & & & & \\
\hline \multirow[t]{2}{*}{ loghomelag2 } & 0.0121 & & -0.0082 & & & \\
\hline & $(0.0198)$ & & $(0.0101)$ & & & \\
\hline \multirow[t]{2}{*}{ loghomelag3 } & -0.00862 & & & 0.000284 & & \\
\hline & $(0.0198)$ & & & $(0.0096)$ & & \\
\hline \multirow[t]{2}{*}{ loghomelag4 } & 0.014 & & & & -0.00699 & \\
\hline & $(0.0192)$ & & & & $(0.0095)$ & \\
\hline \multirow[t]{2}{*}{ loghomelag5 } & -0.0169 & & & & & -0.0102 \\
\hline & $(0.0142)$ & & & & & $(0.0095)$ \\
\hline Average effect & -0.00308 & - & - & - & - & - \\
\hline Year dummies & 24 & 28 & 27 & 26 & 25 & 24 \\
\hline State dummies & 50 & 50 & 50 & 50 & 50 & 50 \\
\hline Other controls & 20 & 20 & 20 & 20 & 20 & 20 \\
\hline Observations & 1,275 & 1,479 & 1,428 & 1,377 & 1,326 & 1,275 \\
\hline R-squared & 0.834 & 0.802 & 0.805 & 0.825 & 0.832 & 0.834 \\
\hline
\end{tabular}

Note: The dependent variable is the state level employment growth rate and the independent variables of interest are the lagged log of the state level home-ownership rates. Other controls include fifteen educational dummies, one sex dummy, two race dummies, one marriage dummy and age. Standard errors are clustered at the state level and are in parentheses. Significance level: $* * * \mathrm{p}<0.01, * * \mathrm{p}<0.05, * \mathrm{p}<0.1$ 
Table 7: GMM result on the relationship of employment growth rates and home-ownership rates

\begin{tabular}{l|llllll}
\hline VARIABLES & \multicolumn{5}{|c}{ emgrowth: GMM } \\
\hline & $1988-2013$ & $1984-2013$ & $1985-2013$ & $1986-2013$ & $1987-2013$ & $1988-2013$ \\
\hline emgrowthlag1 & $0.555^{* * *}$ & $0.596^{* * *}$ & $0.597 * * *$ & $0.585^{* * *}$ & $0.517^{* * *}$ & $0.555^{* * *}$ \\
& $(0.0364)$ & $(0.0254)$ & $(0.0246)$ & $(0.0235)$ & $(0.0383)$ & $(0.0362)$ \\
loghomelag1 & -0.00818 & $-0.0463 * *$ & & & & \\
& $(0.0220)$ & $(0.0206)$ & & & & \\
loghomelag2 & 0.0168 & & 0.00501 & & & \\
& $(0.0237)$ & & $(0.0170)$ & & & \\
loghomelag3 & -0.0113 & & & 0.0193 & & \\
& $(0.0149)$ & & & $(0.0177)$ & & \\
loghomelag4 & 0.0162 & & & & 0.0919 & \\
& $(0.0183)$ & & & & $(0.0159)$ & \\
loghomelag5 & -0.00813 & & & & & 0.000115 \\
& $(0.0184)$ & & & & & \\
Average effect & 0.00108 & & & & & \\
\hline Year dummies & 24 & 28 & 27 & 26 & 25 & 24 \\
State dummies & 50 & 50 & 50 & 50 & 50 & 50 \\
Other controls & 20 & 20 & 20 & 20 & 20 & 20 \\
Observations & 1,224 & 1,428 & 1,377 & 1,326 & 1,275 & 1,224 \\
\hline Note: The depen
\end{tabular}

Note: The dependent variable is the state level employment growth rates and the independent variables of interest are the lagged log of the state level home-ownership rates. Other controls include fifteen educational dummies, one sex dummy, two race dummies, one marriage dummy and age. Standard errors are clustered at the state level and are in parentheses. Significance level: $* * * \mathrm{p}<0.01, * * \mathrm{p}<0.05, * \mathrm{p}<0.1$ 
Figure1: Impulse response function of unemployment

$$
\text { OLS } \log (\text { un) }
$$

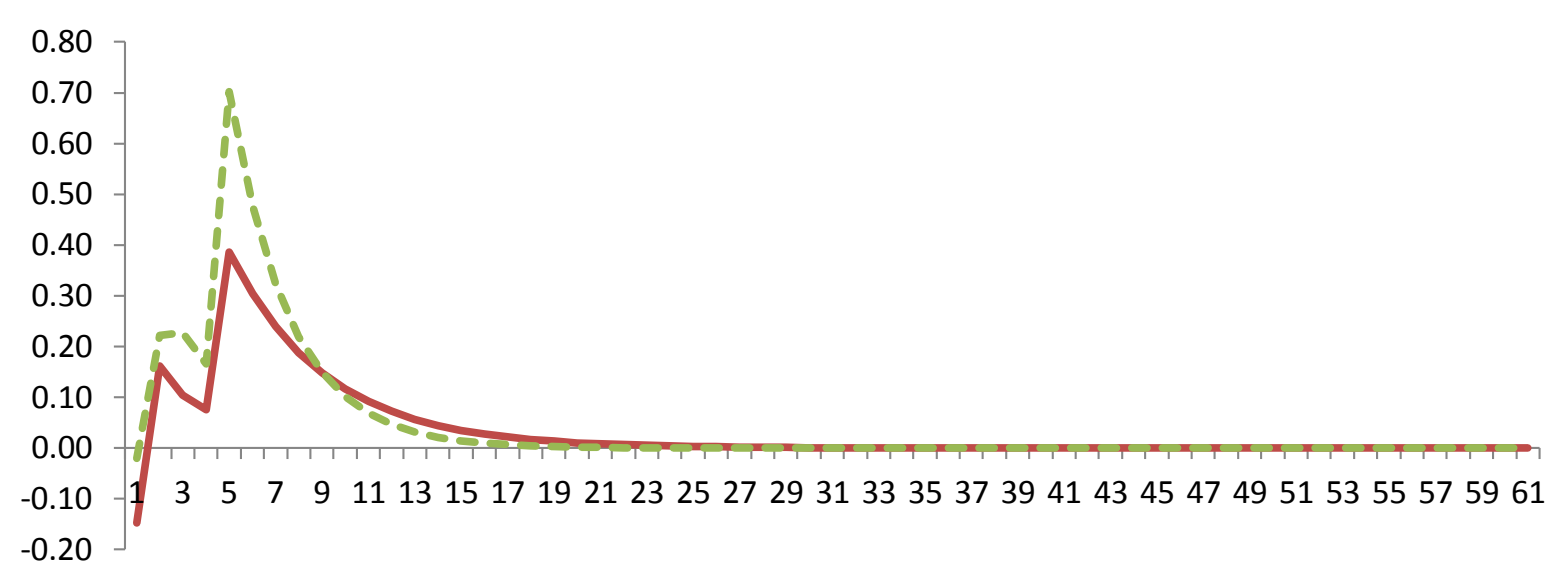

Note: The solid line is the OLS result of the impulse response of the log of the unemployment rates to one unit change in lagged one period home-ownership rates $(t-1)$ at $t, t+1, t+2, \ldots t+k$. The dotted line is the GMM result of the impulse response. The horizontal axis represents the time period after the shock. The vertical axis shows the response to the shock. 
Table 8: Micro-summary statistics for PSID

\begin{tabular}{|c|c|c|c|c|c|c|c|}
\hline Variables & $\begin{array}{l}\text { (1) } \\
\text { Census }\end{array}$ & $\begin{array}{l}(2) \text { Heads of } \\
\text { both owners } \\
\text { and renters } \\
\end{array}$ & $\begin{array}{l}\text { (3) Heads } \\
\text { of renters }\end{array}$ & $\begin{array}{l}\text { (4) Heads } \\
\text { of owners }\end{array}$ & $\begin{array}{l}(5) \text { "Wives }{ }^{18 "} \text { of } \\
\text { both owners and } \\
\text { renters }\end{array}$ & $\begin{array}{l}\text { (6) "Wives" } \\
\text { of renters }\end{array}$ & $\begin{array}{l}(7) \\
\text { "Wives" of } \\
\text { owners } \\
\end{array}$ \\
\hline \multicolumn{8}{|l|}{ Dependent variables: } \\
\hline \multicolumn{8}{|l|}{ Move } \\
\hline 0 Not move & - & $74.54 \%$ & $47.45 \%$ & $87.29 \%$ & $84.16 \%$ & $47.28 \%$ & $89.87 \%$ \\
\hline 3 Involuntary move & - & $9.03 \%$ & $17.84 \%$ & $4.89 \%$ & $4.10 \%$ & $12.85 \%$ & $2.71 \%$ \\
\hline Annual medium wage & 27519 & 35360 & 26000 & 43001 & 26000 & 20000 & 26000 \\
\hline \multicolumn{8}{|l|}{ Independent variables } \\
\hline Homeowners & $65.40 \%$ & $66.80 \%$ & - & - & $84.57 \%$ & - & - \\
\hline \multicolumn{8}{|l|}{ Race } \\
\hline White & $72.41 \%$ & $81.29 \%$ & $70.09 \%$ & $87.55 \%$ & $88.50 \%$ & $76.64 \%$ & $90.45 \%$ \\
\hline Black & $12.61 \%$ & $14.06 \%$ & $24.05 \%$ & $8.49 \%$ & $6.59 \%$ & $14.13 \%$ & $5.44 \%$ \\
\hline Asian & $4.75 \%$ & $1.85 \%$ & $1.95 \%$ & $1.79 \%$ & $2.09 \%$ & $2.80 \%$ & $1.93 \%$ \\
\hline Latino & $16.40 \%$ & $2.80 \%$ & $3.91 \%$ & $2.17 \%$ & $2.82 \%$ & $6.43 \%$ & $2.18 \%$ \\
\hline Married & $58.95 \%$ & $58.80 \%$ & $38.57 \%$ & $70.11 \%$ & $86.92 \%$ & $73.95 \%$ & $86.37 \%$ \\
\hline Male & $49.20 \%$ & $74.38 \%$ & $60.33 \%$ & $82.26 \%$ & $0.00 \%$ & $0.00 \%$ & $0.00 \%$ \\
\hline \multicolumn{8}{|l|}{ City size } \\
\hline Large city (population $>.25 \mathrm{~m}$ ) & - & $67.33 \%$ & $71.14 \%$ & $65.22 \%$ & $65.25 \%$ & $69.72 \%$ & $64.21 \%$ \\
\hline \multicolumn{8}{|l|}{ Age } \\
\hline $18-25$ & $9.9 \%$ & $9.27 \%$ & $21.08 \%$ & $2.67 \%$ & $5.78 \%$ & $20.90 \%$ & $3.23 \%$ \\
\hline $25-35$ & $22.16 \%$ & $24.87 \%$ & $35.27 \%$ & $19.02 \%$ & $22.55 \%$ & $34.30 \%$ & $20.71 \%$ \\
\hline $35-45$ & $22.16 \%$ & $27.90 \%$ & $23.66 \%$ & $30.26 \%$ & $30.98 \%$ & $24.69 \%$ & $32.13 \%$ \\
\hline $45-55$ & $24.29 \%$ & $25.83 \%$ & $14.81 \%$ & $32.02 \%$ & $29.34 \%$ & $15.39 \%$ & $31.45 \%$ \\
\hline $55-65$ & $19.69 \%$ & $12.13 \%$ & $5.18 \%$ & $16.03 \%$ & $11.35 \%$ & $4.72 \%$ & $12.49 \%$ \\
\hline \multicolumn{8}{|l|}{ Homeowner attributes } \\
\hline |Negative equity $\mid>0$ & - & - & - & $2.32 \%$ & - & - & $2.34 \%$ \\
\hline Has mortgages & - & - & - & $82.82 \%$ & - & - & $84.84 \%$ \\
\hline
\end{tabular}

Note: The table reports the calculations of the PSID data based on weights. Data period is from 1994 to 2011 for every two years, except that for the "move" variable, which is from 2001 to 2011. The first column (1) is from the 2012 census data.

\footnotetext{
18

Within each wave of data, each family unit has one and only one current Head. Originally, if the family contained a husband-wife pair, the husband was arbitrarily designated the "Head" and the other the "Wife".
} 
Table 9: The effect of home-ownership on unemployment probabilities for heads

\begin{tabular}{|c|c|c|c|c|c|}
\hline Unemployment probability & OLS & Logit & $\mathrm{RE}$ & $\mathrm{FE}$ & Logit-IV \\
\hline Home-ownership & $\begin{array}{l}-.043 * * * \\
(.003)\end{array}$ & $\begin{array}{l}-.030 * * * \\
(.002)\end{array}$ & $\begin{array}{l}-.606 * * * \\
(.057)\end{array}$ & $\begin{array}{l}-.023 \\
(.084)\end{array}$ & $\begin{array}{l}-.009 * * \\
(.003)\end{array}$ \\
\hline $\begin{array}{l}\text { State home-ownership rates } \\
65 \%-70 \%\end{array}$ & $\begin{array}{l}-.006 \\
(.005)\end{array}$ & $\begin{array}{l}-.001 \\
(.004)\end{array}$ & $\begin{array}{l}-.043 \\
(.107)\end{array}$ & $\begin{array}{l}.017 \\
(.131)\end{array}$ & $\begin{array}{l}.002 \\
(.004)\end{array}$ \\
\hline $70 \%-$ & $\begin{array}{l}-.008 \\
(.006)\end{array}$ & $\begin{array}{l}-.002 \\
(.005)\end{array}$ & $\begin{array}{l}-.078 \\
(.132)\end{array}$ & $\begin{array}{l}-.003 \\
(.158)\end{array}$ & $\begin{array}{l}.000 \\
(.007)\end{array}$ \\
\hline Married & $\begin{array}{l}-.045 * * * \\
(.004)\end{array}$ & $\begin{array}{l}-.031 * * * \\
(.002)\end{array}$ & $\begin{array}{l}-.814 * * * \\
(.068)\end{array}$ & $\begin{array}{l}- \\
(-)\end{array}$ & $\begin{array}{l}-.028 * * * \\
(.003)\end{array}$ \\
\hline Children number & $\begin{array}{l}.011 * * * \\
(.001)\end{array}$ & $\begin{array}{l}.006 * * * \\
(.000)\end{array}$ & $\begin{array}{l}.156^{* * * *} \\
(.020)\end{array}$ & $\begin{array}{l}.084 * * \\
(.033)\end{array}$ & $\begin{array}{l}.006 * * * \\
(.000)\end{array}$ \\
\hline Male & $\begin{array}{l}.005 \\
(.005)\end{array}$ & $\begin{array}{l}.005 * * \\
(.002)\end{array}$ & $\begin{array}{l}.062 \\
(.071)\end{array}$ & $\begin{array}{l}- \\
(-)\end{array}$ & $\begin{array}{l}.010^{* * * *} \\
(.003)\end{array}$ \\
\hline Black & $\begin{array}{l}.049 * * * \\
(.004)\end{array}$ & $\begin{array}{l}.033 * * * \\
(.003)\end{array}$ & $\begin{array}{l}.816^{* * * *} \\
(.069)\end{array}$ & $\begin{array}{l}.447 \\
(.599)\end{array}$ & $\begin{array}{l}.034 * * * \\
(.004)\end{array}$ \\
\hline Asian & $\begin{array}{l}-.014 \\
(.009)\end{array}$ & $\begin{array}{l}-.008 \\
(.008)\end{array}$ & $\begin{array}{l}-.235 \\
(.293)\end{array}$ & $\begin{array}{l}.052 \\
(.000)\end{array}$ & $\begin{array}{l}-.001 \\
(.010)\end{array}$ \\
\hline Latino & $\begin{array}{l}.013 \\
(.010)\end{array}$ & $\begin{array}{l}.014 * \\
(.007)\end{array}$ & $\begin{array}{l}.248 \\
(.171)\end{array}$ & $\begin{array}{l}-.424 \\
(.296)\end{array}$ & $\begin{array}{c}.009 \\
(.008)\end{array}$ \\
\hline B.S. & $\begin{array}{l}-.029 * * * \\
(.002)\end{array}$ & $\begin{array}{l}-.030 * * * \\
(.002)\end{array}$ & $\begin{array}{l}-.891 * * * \\
(.092)\end{array}$ & $\begin{array}{l}-.199 \\
(.278)\end{array}$ & $\begin{array}{l}-.023 * * * \\
(.003)\end{array}$ \\
\hline M.S. & $\begin{array}{l}-.036 * * * \\
(.003)\end{array}$ & $\begin{array}{l}-.041 * * * \\
(.003)\end{array}$ & $\begin{array}{l}-1.328 * * * \\
(.177)\end{array}$ & $\begin{array}{l}-.119 \\
(.418)\end{array}$ & $\begin{array}{l}-.036 * * * \\
(.003)\end{array}$ \\
\hline "Wife" works & $\begin{array}{l}-.007 * * \\
(.003)\end{array}$ & $\begin{array}{l}-.008 * * * \\
(.002)\end{array}$ & $\begin{array}{l}-.151^{* *} \\
(.064)\end{array}$ & $\begin{array}{l}.021 \\
(.087)\end{array}$ & $\begin{array}{l}-.007 * * \\
(.003)\end{array}$ \\
\hline Age & & & & & \\
\hline $25-35$ & $\begin{array}{l}-.025 * * * \\
(.005)\end{array}$ & $\begin{array}{l}-.014 * * * \\
(.003)\end{array}$ & $\begin{array}{l}-.343 * * * \\
(.071)\end{array}$ & $\begin{array}{l}-.301 * * * \\
(.116)\end{array}$ & $\begin{array}{l}-.011^{* *} \\
(.004)\end{array}$ \\
\hline $35-45$ & $\begin{array}{l}-.024 * * * \\
(.006)\end{array}$ & $\begin{array}{l}-.012 * * * \\
(.003)\end{array}$ & $\begin{array}{l}-.352 * * * \\
(.077)\end{array}$ & $\begin{array}{l}-.297 * \\
(.179)\end{array}$ & $\begin{array}{l}-.010 * * \\
(.005)\end{array}$ \\
\hline $45-55$ & $\begin{array}{l}-.019 * * * \\
(.005)\end{array}$ & $\begin{array}{l}-.0118^{* * * *} \\
(.004)\end{array}$ & $\begin{array}{l}-.282 * * * \\
(.087)\end{array}$ & $\begin{array}{l}-.052 \\
(.250)\end{array}$ & $\begin{array}{l}-.008 \\
(.005)\end{array}$ \\
\hline $55-$ & $\begin{array}{l}-.022 * * * \\
(.006)\end{array}$ & $\begin{array}{l}-.015^{* * *} \\
(.005)\end{array}$ & $\begin{array}{l}-.330 * * * \\
(.119)\end{array}$ & $\begin{array}{l}.168 \\
(.339)\end{array}$ & $\begin{array}{l}-.014 * * \\
(.006)\end{array}$ \\
\hline Constant & $\begin{array}{l}.101 * * * \\
(.020)\end{array}$ & $\begin{array}{l}.051 * * * \\
(.001)\end{array}$ & $\begin{array}{c}-3.724 \\
(9.262)\end{array}$ & $\begin{array}{l}- \\
(-)\end{array}$ & $\begin{array}{l}.052 * * * \\
(.001)\end{array}$ \\
\hline TIME FE & 9 & 9 & 9 & 9 & 9 \\
\hline STATE FE & 50 & 50 & 50 & 50 & 50 \\
\hline Obs & 49333 & 49287 & 49333 & 10836 & 49287 \\
\hline
\end{tabular}

Note: We use the annual PSID data from 1994 to 2011 to test the impact with five model specifications: OLS, logit, fixed effects (FE), random effects (RE) and IV for logit. The instrument we use for home-ownership is the state marginal tax rate. Coefficients are marginal effects. Standard errors are clustered at the individual level and are in parentheses. Significance level: $* * * \mathrm{p}<0.01, * * \mathrm{p}<0.05, * \mathrm{p}<0.1$ 
Table 9.1: The effect of home-ownership on unemployment probabilities for "wives"

\begin{tabular}{|c|c|c|c|}
\hline Unemployment probability & OLS & Logit & Logit-IV \\
\hline Home-ownership & $\begin{array}{l}-.041 * * * \\
(.004)\end{array}$ & $\begin{array}{l}-.025 * * * \\
(.002)\end{array}$ & $\begin{array}{l}.000 \\
(.004)\end{array}$ \\
\hline $\begin{array}{l}\text { State home-ownership rates } \\
65 \%-70 \%\end{array}$ & $\begin{array}{l}-.003 \\
(.006)\end{array}$ & $\begin{array}{c}-.002 \\
(.004)\end{array}$ & $\begin{array}{l}-.002 \\
(.004)\end{array}$ \\
\hline $70 \%-$ & $\begin{array}{l}.004 \\
(.007)\end{array}$ & $\begin{array}{l}.004 \\
(.006)\end{array}$ & $\begin{array}{l}.004 \\
(.006)\end{array}$ \\
\hline Married & $\begin{array}{l}-.007 \\
(.005)\end{array}$ & $\begin{array}{l}-.004 \\
(.003)\end{array}$ & $\begin{array}{l}-.008 * * \\
(.003)\end{array}$ \\
\hline Children number & $\begin{array}{l}.000 \\
.001)\end{array}$ & $\begin{array}{l}.000 \\
(.001)\end{array}$ & $\begin{array}{l}-.000 \\
(.001)\end{array}$ \\
\hline Male & - & - & - \\
\hline Black & $\begin{array}{l}.020 * * * \\
(.004)\end{array}$ & $\begin{array}{l}.015 * * * \\
(.003)\end{array}$ & $\begin{array}{l}.023 * * * \\
(.004)\end{array}$ \\
\hline Asian & $\begin{array}{l}.006 \\
(.011)\end{array}$ & $\begin{array}{l}.007 \\
(.009)\end{array}$ & $\begin{array}{l}.008 \\
(.009)\end{array}$ \\
\hline Latino & $\begin{array}{l}.039 * * \\
(.016)\end{array}$ & $\begin{array}{l}.031 * * \\
(.012)\end{array}$ & $\begin{array}{l}.039 * * * \\
(.013)\end{array}$ \\
\hline B.S. & $\begin{array}{l}-.018 * * * \\
. .003)\end{array}$ & $\begin{array}{l}-.016^{* * * *} \\
(.003)\end{array}$ & $\begin{array}{l}-.018 * * * \\
(.003)\end{array}$ \\
\hline M.S. & $\begin{array}{l}-.020 * * * \\
(.004)\end{array}$ & $\begin{array}{l}-.020 * * * \\
(.003)\end{array}$ & $\begin{array}{l}-.022 * * * \\
(.003)\end{array}$ \\
\hline Husband works & $\begin{array}{l}-.005 \\
(.005)\end{array}$ & $\begin{array}{l}-.004 \\
(.003)\end{array}$ & $\begin{array}{l}-.005 \\
(.003)\end{array}$ \\
\hline Age & & & \\
\hline $25-35$ & $\begin{array}{l}-.016^{* *} \\
(.006)\end{array}$ & $\begin{array}{l}-.009 * * \\
(.004)\end{array}$ & $\begin{array}{l}-.021 * * * \\
(.007)\end{array}$ \\
\hline $35-45$ & $\begin{array}{l}-.016^{* * *} \\
(.007)\end{array}$ & $\begin{array}{l}-.010^{* *} \\
(.004)\end{array}$ & $\begin{array}{l}-.026^{* * *} \\
(.007)\end{array}$ \\
\hline $45-55$ & $\begin{array}{l}-.019 * * * \\
(.006)\end{array}$ & $\begin{array}{l}-.013 * * * \\
(.004)\end{array}$ & $\begin{array}{l}-.031 * * * \\
(.007)\end{array}$ \\
\hline $55-$ & $\begin{array}{l}-.019 * * \\
(.008)\end{array}$ & $\begin{array}{l}-.012 * * \\
(.006)\end{array}$ & $\begin{array}{l}-.031 * * * \\
(.008)\end{array}$ \\
\hline Constant & $\begin{array}{l}.109 * * * \\
(.025)\end{array}$ & $\begin{array}{l}.034 * * * \\
(.001)\end{array}$ & $\begin{array}{l}.035 * * * \\
(.001)\end{array}$ \\
\hline TIME FE & 9 & 9 & 9 \\
\hline STATE FE & 50 & 50 & 50 \\
\hline Obs & 23962 & 23915 & 23915 \\
\hline
\end{tabular}

Note: We use the annual PSID data from 1994 to 2011 to test the impact with three model specifications: OLS, logit, and IV for logit. The instrument we use for home-ownership is the state marginal tax rate. Coefficients are marginal effects. Standard errors are clustered at the individual level and are in parentheses. Significance level: $* * *$ $\mathrm{p}<0.01, * * \mathrm{p}<0.05, * \mathrm{p}<0.1$ 
Table 10: First stage regression of IV for Table 9

\begin{tabular}{|c|c|c|c|}
\hline Home-ownership & Coef. & & Coef. \\
\hline State home-ownership rate & $\begin{array}{l}3.061 * * * \\
(.473)\end{array}$ & Tax rate & $\begin{array}{l}2.311 * * \\
(.975)\end{array}$ \\
\hline State home-ownership rates & & State home-ownership rates & \\
\hline $65 \%-70 \%$ & $\begin{array}{l}0.004 \\
(.055)\end{array}$ & $65 \%-70 \%$ & $\begin{array}{l}-0.003 \\
(.053)\end{array}$ \\
\hline $70 \%-$ & $\begin{array}{l}0.007 \\
(.069)\end{array}$ & $70 \%-$ & $\begin{array}{l}0.024 \\
(.066)\end{array}$ \\
\hline Married & $\begin{array}{l}.797 * * * \\
(.027)\end{array}$ & Married & $\begin{array}{l}.594 * * * \\
(.027)\end{array}$ \\
\hline Children number & $\begin{array}{l}.079 * * * \\
(.010)\end{array}$ & Children number & $\begin{array}{l}.142 * * * \\
(.009)\end{array}$ \\
\hline Male & $\begin{array}{l}.089 * * * \\
(.031)\end{array}$ & Male & $\begin{array}{l}.207 * * * \\
(.031)\end{array}$ \\
\hline Black & $\begin{array}{l}-1.073 * * * \\
(.029)\end{array}$ & Black & $\begin{array}{l}-1.076 * * * \\
(.028)\end{array}$ \\
\hline Asian & $\begin{array}{l}-.238 * * \\
(.101)\end{array}$ & Asian & $\begin{array}{l}-.376 * * * \\
(.098)\end{array}$ \\
\hline Latino & $\begin{array}{l}-.554 * * * \\
(.077)\end{array}$ & Latino & $\begin{array}{l}-.595 * * * \\
(.075)\end{array}$ \\
\hline B.S. & $\begin{array}{l}.577 * * * \\
(.033)\end{array}$ & B.S. & $\begin{array}{l}.473 * * * \\
(.031)\end{array}$ \\
\hline M.S. & $\begin{array}{l}.652 * * * \\
(.058)\end{array}$ & M.S. & $\begin{array}{l}.572 * * * \\
(.056)\end{array}$ \\
\hline "Wife" works & $\begin{array}{l}.822 * * * \\
(.028)\end{array}$ & "Wife" works & $\begin{array}{l}.896^{* * * *} \\
(.028)\end{array}$ \\
\hline Age & & Age & \\
\hline $25-35$ & $\begin{array}{l}.983^{* * * *} \\
(.040)\end{array}$ & $25-35$ & $\begin{array}{l}1.151 \text { *** } \\
(.042)\end{array}$ \\
\hline $35-45$ & $\begin{array}{l}1.759 * * * \\
(.041)\end{array}$ & $35-45$ & $\begin{array}{l}2.088 * * * \\
(.042)\end{array}$ \\
\hline $45-55$ & $\begin{array}{l}2.313 * * * \\
(.044)\end{array}$ & $45-55$ & $\begin{array}{l}2.741 \text { *** } \\
(.045)\end{array}$ \\
\hline $55-$ & $\begin{array}{l}2.709 * * * \\
(.060)\end{array}$ & $55-$ & $\begin{array}{l}3.204 * * * \\
(.060)\end{array}$ \\
\hline Constant & $\begin{array}{l}-3.239 * * * \\
(.350)\end{array}$ & Constant & $\begin{array}{l}-1.518 * * * \\
(.278)\end{array}$ \\
\hline TIME FE & 9 & TIME FE & 9 \\
\hline STATE FE & 50 & STATE FE & 50 \\
\hline Obs & 47948 & Obs & 49392 \\
\hline
\end{tabular}

Note: We use the annual PSID data from 1994 to 2011. The dependent variable is whether the person is an owner or not. The instruments are state level home-ownership rates and marginal tax rates. In Tables 9 and 9.1, we only report the results with the state level marginal tax rate as the instrument because the estimation results are quite similar when using the home-ownership rates. Standard errors are clustered at the individual level and are in parentheses. Significance level: $* * * \mathrm{p}<0.01, * * \mathrm{p}<0.05, * \mathrm{p}<0.1$ 
Table 11: The impact of home-ownership on the hazard rate from unemployment to employment

\begin{tabular}{|c|c|c|c|c|c|}
\hline Hazard rate from unemployment to employment & (1) $\mathrm{PH}$ & (2)PH- IV & (3) OLS & (4) Logit & (5) Logit-IV \\
\hline Home-ownership & $\begin{array}{l}1.022 * * * \\
(.003)\end{array}$ & $\begin{array}{l}1.033 * * * \\
(.005)\end{array}$ & $\begin{array}{l}1.013 * * * \\
(.001)\end{array}$ & $\begin{array}{l}1.192 * * * \\
(.016)\end{array}$ & $\begin{array}{l}1.041 \\
(.024)\end{array}$ \\
\hline $\begin{array}{l}\text { State home-ownership rates } \\
65 \%-70 \%\end{array}$ & $\begin{array}{l}1.011 * \\
(.006)\end{array}$ & $\begin{array}{l}1.010 * \\
(.006)\end{array}$ & $\begin{array}{l}1.006 * * * \\
(.002)\end{array}$ & $\begin{array}{l}1.090 * * * \\
(.028)\end{array}$ & $\begin{array}{l}1.098 * * * \\
(.027)\end{array}$ \\
\hline $70 \%-$ & $\begin{array}{l}1.014 * \\
(.008)\end{array}$ & $\begin{array}{l}1.015^{*} \\
(.008)\end{array}$ & $\begin{array}{l}1.009 * * * \\
(.003)\end{array}$ & $\begin{array}{l}1.120 * * * \\
(.040)\end{array}$ & $\begin{array}{l}1.131 * * * \\
(.040)\end{array}$ \\
\hline Married & $\begin{array}{l}1.009 * * * \\
(.003)\end{array}$ & $\begin{array}{l}1.004 \\
(.003)\end{array}$ & $\begin{array}{l}1.015 * * * \\
(.001)\end{array}$ & $\begin{array}{l}1.259 * * * \\
(.018)\end{array}$ & $\begin{array}{l}1.307 * * * \\
(.019)\end{array}$ \\
\hline Metro & $\begin{array}{l}0.986 * * * \\
(.004)\end{array}$ & $\begin{array}{l}0.996 * * * \\
(.001)\end{array}$ & $\begin{array}{l}0.999 \\
(.002)\end{array}$ & $\begin{array}{l}0.984 \\
(.021)\end{array}$ & $\begin{array}{l}0.988 \\
(.021)\end{array}$ \\
\hline Children number & $\begin{array}{l}0.996 * * * \\
(.001)\end{array}$ & $\begin{array}{l}.996 * * * \\
(.001)\end{array}$ & $\begin{array}{l}0.995 * * * \\
(.001)\end{array}$ & $\begin{array}{l}0.941 * * * \\
(.007)\end{array}$ & $\begin{array}{l}0.942 * * * \\
(.007)\end{array}$ \\
\hline Male & $\begin{array}{l}1.009 * * * \\
(.002)\end{array}$ & $\begin{array}{l}1.011 * * * \\
(.002)\end{array}$ & $\begin{array}{l}1.005 * * * \\
(.001)\end{array}$ & $\begin{array}{l}1.077 * * * \\
(.016)\end{array}$ & $\begin{array}{l}1.076^{* * * *} \\
(.016)\end{array}$ \\
\hline Black & $\begin{array}{l}0.978 * * * \\
(.004)\end{array}$ & $\begin{array}{l}0.987 * * * \\
(.004)\end{array}$ & $\begin{array}{l}1.003 * \\
(.002)\end{array}$ & $\begin{array}{l}1.040 \\
(.025)\end{array}$ & $\begin{array}{l}0.986 \\
(.026)\end{array}$ \\
\hline Asian & $\begin{array}{l}1.002 \\
(.006)\end{array}$ & $\begin{array}{l}1.004 \\
(.006)\end{array}$ & $\begin{array}{l}1.009 * * * \\
(.002)\end{array}$ & $\begin{array}{l}1.173 * * * \\
(.040)\end{array}$ & $\begin{array}{l}1.151^{* * * *} \\
(.040)\end{array}$ \\
\hline Latino & $\begin{array}{l}0.973 * * * \\
(.008)\end{array}$ & $\begin{array}{l}0.977 * * * \\
(.008)\end{array}$ & $\begin{array}{l}0.992 * * \\
(.003)\end{array}$ & $\begin{array}{l}0.916^{* * *} \\
(.039)\end{array}$ & $\begin{array}{l}0.891 * * * \\
(.039)\end{array}$ \\
\hline $\mathrm{BS}$ & $\begin{array}{l}1.037 * * * \\
(.003)\end{array}$ & $\begin{array}{l}1.036 * * * \\
(.003)\end{array}$ & $\begin{array}{l}1.021 * * * \\
(.001)\end{array}$ & $\begin{array}{l}1.399 * * * \\
(.022)\end{array}$ & $\begin{array}{l}1.433 * * * \\
(.022)\end{array}$ \\
\hline MS & $\begin{array}{l}1.043 * * * \\
(.003)\end{array}$ & $\begin{array}{l}1.042 * * * \\
(.003)\end{array}$ & $\begin{array}{l}1.019 * * * \\
(.002)\end{array}$ & $\begin{array}{l}1.396 * * * \\
(.034)\end{array}$ & $\begin{array}{l}1.437 * * * \\
(.034)\end{array}$ \\
\hline \multicolumn{6}{|l|}{ Age } \\
\hline $25-35$ & $\begin{array}{l}1.013^{* *} \\
(.005)\end{array}$ & $\begin{array}{l}1.022 * * * \\
(.005)\end{array}$ & $\begin{array}{l}1.083 * * * \\
(.002)\end{array}$ & $\begin{array}{l}2.098 * * * \\
(.021)\end{array}$ & $\begin{array}{l}2.022 * * * \\
(.022)\end{array}$ \\
\hline $35-45$ & $\begin{array}{l}1.025^{* * * *} \\
(.005)\end{array}$ & $\begin{array}{l}1.027 * * * \\
(.005)\end{array}$ & $\begin{array}{l}1.098 * * * \\
(.002)\end{array}$ & $\begin{array}{l}2.639 * * * \\
(.024)\end{array}$ & $\begin{array}{l}2.627 * * * \\
(.024)\end{array}$ \\
\hline $45-55$ & $\begin{array}{l}1.033^{* * * *} \\
(.005)\end{array}$ & $\begin{array}{l}1.035^{* * * *} \\
(.005)\end{array}$ & $\begin{array}{l}1.096 * * * \\
(.002)\end{array}$ & $\begin{array}{l}2.620 * * * \\
(.024)\end{array}$ & $\begin{array}{l}2.674 * * * \\
(.024)\end{array}$ \\
\hline $55-$ & $\begin{array}{l}1.026^{* * * *} \\
(.006)\end{array}$ & $\begin{array}{l}1.028 * * * \\
(.005)\end{array}$ & $\begin{array}{l}1.077 * * * \\
(.002)\end{array}$ & $\begin{array}{l}1.956 * * * \\
(.027)\end{array}$ & $\begin{array}{l}2.004 * * * \\
(.027)\end{array}$ \\
\hline TIME FE & 60 & 60 & 60 & 60 & 60 \\
\hline STATE FE & 50 & 50 & 50 & 50 & 50 \\
\hline Obs & 1648779 & 1696420 & 1648779 & 1648779 & 1696420 \\
\hline
\end{tabular}

Note: We use SIPP monthly data from panel 2008 (2008-2013) for this estimation. The dependent variable is the hazard rate from unemployment to employment. We use five specifications. The first (1) is the proportional hazard (PH) rate model with Weibull distribution as the baseline hazard distribution. The second (2) is the IV of (1) with marginal tax rate as the instrument for home-ownership. The third (3) uses OLS to estimate the hazard rate with a conditional regression, where whether the person is employed or not is the dependent variable and the time length that the person has already been unemployed is one of the independent variables. The fourth (4) is the logit form of (3). The fifth (5) is the IV of (4) with tax rate as the instrument for home-ownership. Coefficients larger than one indicate that people are more likely to leave unemployment with the increase of right hand side variables. Standard errors are clustered at the individual level and are in parentheses. Significance level: $* * *$ $\mathrm{p}<0.01, * * \mathrm{p}<0.05, * \mathrm{p}<0.1$ 
Table 11.1: The impact of home-ownership on unemployment spell length

\begin{tabular}{|c|c|c|c|c|}
\hline Unemployment spell length & (1) OLS & (2) AFT & (3) OLS- IV & (4) AFT-IV \\
\hline Home-ownership & $\begin{array}{l}-0.031 * * * \\
(.005)\end{array}$ & $\begin{array}{l}-0.015^{* * *} \\
(.002)\end{array}$ & $\begin{array}{l}-0.01 \\
(.009)\end{array}$ & $\begin{array}{l}-0.029 * * * \\
(.004)\end{array}$ \\
\hline $\begin{array}{l}\text { State home-ownership rates } \\
65 \%-70 \%\end{array}$ & $\begin{array}{l}-0.016^{*} \\
(.009)\end{array}$ & $\begin{array}{l}-0.007 * \\
(.004)\end{array}$ & $\begin{array}{l}-0.018 * * \\
(.009)\end{array}$ & $\begin{array}{l}-0.007 * \\
(.004)\end{array}$ \\
\hline $70 \%-$ & $\begin{array}{l}-0.016 \\
(.012)\end{array}$ & $\begin{array}{l}-0.010^{*} \\
(.005)\end{array}$ & $\begin{array}{l}-0.018 \\
(.013)\end{array}$ & $\begin{array}{l}-0.010^{*} \\
(.005)\end{array}$ \\
\hline Married & $\begin{array}{l}-0.054 * * * \\
(.006)\end{array}$ & $\begin{array}{l}-0.006^{* * *} \\
(.002)\end{array}$ & $\begin{array}{l}-0.058^{* * *} \\
(.007)\end{array}$ & $\begin{array}{l}-0.003 \\
(.002)\end{array}$ \\
\hline Metro & $\begin{array}{l}0.009 \\
(.008)\end{array}$ & $\begin{array}{l}0.010^{* * * *} \\
(.002)\end{array}$ & $\begin{array}{l}0.009 \\
(.008)\end{array}$ & $\begin{array}{l}0.011 * * * \\
(.002)\end{array}$ \\
\hline Children number & $\begin{array}{l}0.014 * * * \\
(.002)\end{array}$ & $\begin{array}{l}0.003 * * * \\
(.001)\end{array}$ & $\begin{array}{l}0.015^{* * *} \\
(.002)\end{array}$ & $\begin{array}{l}0.003 * * * \\
(.001)\end{array}$ \\
\hline Male & $\begin{array}{l}-0.006 \\
(.005)\end{array}$ & $\begin{array}{l}-0.006 * * * \\
(.002)\end{array}$ & $\begin{array}{l}-0.006 \\
(.005)\end{array}$ & $\begin{array}{l}-0.008^{* * *} \\
(.002)\end{array}$ \\
\hline Black & $\begin{array}{l}-0.001 \\
(.008)\end{array}$ & $\begin{array}{l}0.015^{* * * *} \\
(.003)\end{array}$ & $\begin{array}{l}0.001 \\
(.009)\end{array}$ & $\begin{array}{l}0.009 * * * \\
(.003)\end{array}$ \\
\hline Asian & $\begin{array}{l}-0.036 * * * \\
(.008)\end{array}$ & $\begin{array}{l}-0.001 \\
(.004)\end{array}$ & $\begin{array}{l}-0.036^{* * *} \\
(.009)\end{array}$ & $\begin{array}{l}-0.002 \\
(.004)\end{array}$ \\
\hline Latino & $\begin{array}{l}0.026^{*} \\
(.014)\end{array}$ & $\begin{array}{l}0.019 * * * \\
(.005)\end{array}$ & $\begin{array}{l}0.027^{*} \\
(.014)\end{array}$ & $\begin{array}{l}0.016 * * * \\
(.005)\end{array}$ \\
\hline BS & $\begin{array}{l}-0.054 * * * \\
(.006)\end{array}$ & $\begin{array}{l}-0.025^{* * *} \\
(.002)\end{array}$ & $\begin{array}{l}-0.058^{* * *} \\
(.006)\end{array}$ & $\begin{array}{l}-0.025^{* * *} \\
(.002)\end{array}$ \\
\hline MS & $\begin{array}{l}-0.038 * * * \\
(.010)\end{array}$ & $\begin{array}{l}-0.029 * * * \\
(.002)\end{array}$ & $\begin{array}{l}-0.042 * * * \\
(.010)\end{array}$ & $\begin{array}{l}-0.029 * * * \\
(.002)\end{array}$ \\
\hline Age & & & & \\
\hline $25-35$ & $\begin{array}{l}-0.202 * * * \\
(.008)\end{array}$ & $\begin{array}{l}-0.009 * * \\
(.004)\end{array}$ & $\begin{array}{l}-0.208 * * * \\
(.009)\end{array}$ & $\begin{array}{l}-0.015 * * * \\
(.004)\end{array}$ \\
\hline $35-45$ & $\begin{array}{l}-0.240 * * * \\
(.008)\end{array}$ & $\begin{array}{l}-0.017 * * * \\
(.004)\end{array}$ & $\begin{array}{l}-0.249 * * * \\
(.008)\end{array}$ & $\begin{array}{l}-0.019 * * * \\
(.004)\end{array}$ \\
\hline $45-55$ & $\begin{array}{l}-0.232 * * * \\
(.008)\end{array}$ & $\begin{array}{l}-0.023 * * * \\
(.004)\end{array}$ & $\begin{array}{l}-0.242 * * * \\
(.009)\end{array}$ & $\begin{array}{l}-0.024 * * * \\
(.004)\end{array}$ \\
\hline $55-$ & $\begin{array}{l}-0.165^{* * * *} \\
(.011)\end{array}$ & $\begin{array}{l}-0.018^{* * * *} \\
(.004)\end{array}$ & $\begin{array}{l}-0.174 * * * \\
(.012)\end{array}$ & $\begin{array}{l}-0.020 * * * \\
(.004)\end{array}$ \\
\hline TIME FE & 60 & 60 & 60 & 60 \\
\hline STATE FE & 50 & 50 & 50 & 50 \\
\hline Obs & 1704276 & 1648779 & 1696590 & 1696420 \\
\hline
\end{tabular}

Note: We use SIPP monthly data from panel 2008 (2008-2013) for this estimation. The dependent variable is the unemployment spell length. We use four specifications. The first (1) is the OLS with the unemployment spell length as the dependent variable. The second (2) is the accelerated failure-time (AFT) model with the unemployment length as the dependent variable. AFT is the same as PH in Table 11 except that PH uses the hazard rate as the dependent variable and AFT uses the unemployment duration as the dependent variable. (3) and (4) are the IVs for (1) and (2) with marginal tax rate as the instrument for home-ownership. Negative coefficients indicate shorter unemployment spells with the increase of right hand side variables. Standard errors are clustered at the individual level and are in parentheses. Significance level: $* * * \mathrm{p}<0.01$, $* *$ $\mathrm{p}<0.05, * \mathrm{p}<0.1$ 
Table 12: The impact of home-ownership on the hazard rate from employment to unemployment

\begin{tabular}{|c|c|c|c|c|c|}
\hline Hazard rate from employment to unemployment & (1) $\mathrm{PH}$ & (2)PH-IV & (3)OLS & (4)Logit & (5)Logit-IV \\
\hline Home-ownership & $\begin{array}{l}0.873 * * * \\
(.014)\end{array}$ & $\begin{array}{l}0.958 * * \\
(.021)\end{array}$ & $\begin{array}{l}0.987 * * * \\
(.001)\end{array}$ & $\begin{array}{l}0.839 * * * \\
(.016)\end{array}$ & $\begin{array}{l}0.950 * * \\
(.024)\end{array}$ \\
\hline \\
\hline $65 \%-70 \%$ & $\begin{array}{l}0.929 * * * \\
(.025)\end{array}$ & $\begin{array}{l}0.926 * * * \\
(.025)\end{array}$ & $\begin{array}{l}0.994 * * * \\
(.002)\end{array}$ & $\begin{array}{l}0.917 * * * \\
(.028)\end{array}$ & $\begin{array}{l}0.913 * * * \\
(.028)\end{array}$ \\
\hline $70 \%-$ & $\begin{array}{l}0.909 * * * \\
(.036)\end{array}$ & $\begin{array}{l}0.903 * * * \\
(.037)\end{array}$ & $\begin{array}{l}0.992 * * * \\
(.003)\end{array}$ & $\begin{array}{l}0.893 * * * \\
(.040)\end{array}$ & $\begin{array}{l}0.886^{* * * *} \\
(.041)\end{array}$ \\
\hline Married & $\begin{array}{l}0.823 * * * \\
(.016)\end{array}$ & $\begin{array}{l}0.820 * * * \\
(.017)\end{array}$ & $\begin{array}{l}0.985 * * * \\
(.001)\end{array}$ & $\begin{array}{l}0.794 * * * \\
(.018)\end{array}$ & $\begin{array}{l}0.790 * * * \\
(.019)\end{array}$ \\
\hline Metro & $\begin{array}{l}0.995 \\
(.019)\end{array}$ & $\begin{array}{l}0.990 \\
(.019)\end{array}$ & $\begin{array}{l}1.001 \\
(.002)\end{array}$ & $\begin{array}{l}1.016 \\
(.021)\end{array}$ & $\begin{array}{l}1.011 \\
(.022)\end{array}$ \\
\hline Children number & $\begin{array}{l}1.052 * * * \\
(.006)\end{array}$ & $\begin{array}{l}1.048 * * * \\
(.006)\end{array}$ & $\begin{array}{l}1.005 * * * \\
(.001)\end{array}$ & $\begin{array}{l}1.063 * * * \\
(.007)\end{array}$ & $\begin{array}{l}1.058 * * * \\
(.007)\end{array}$ \\
\hline Male & $\begin{array}{l}0.937 \\
(.014)\end{array}$ & $\begin{array}{l}0.936 * * * \\
(.014)\end{array}$ & $\begin{array}{l}0.995 * * * \\
(.001)\end{array}$ & $\begin{array}{l}0.928 * * * \\
(.016)\end{array}$ & $\begin{array}{l}0.927 \\
(.016)\end{array}$ \\
\hline Black & $\begin{array}{l}0.937 * * * \\
(.021)\end{array}$ & $\begin{array}{l}0.940 * * * \\
(.024)\end{array}$ & $\begin{array}{l}0.997 * \\
(.002)\end{array}$ & $\begin{array}{l}0.961 \\
(.025)\end{array}$ & $\begin{array}{l}0.969 \\
(.027)\end{array}$ \\
\hline Asian & $\begin{array}{l}0.847 * * * \\
(.036)\end{array}$ & $\begin{array}{l}0.842 * * * \\
(.037)\end{array}$ & $\begin{array}{l}0.991 * * * \\
(.002)\end{array}$ & $\begin{array}{l}0.852 * * * \\
(.040)\end{array}$ & $\begin{array}{l}0.849 * * * \\
(.041)\end{array}$ \\
\hline Latino & $\begin{array}{l}1.055 \\
(.033)\end{array}$ & $\begin{array}{l}1.056 \\
(.034)\end{array}$ & $\begin{array}{l}1.008 * * \\
(.003)\end{array}$ & $\begin{array}{l}1.092 * * \\
(.039)\end{array}$ & $\begin{array}{l}1.091 * * \\
(.040)\end{array}$ \\
\hline BS & $\begin{array}{l}0.760 * * * \\
(.020)\end{array}$ & $\begin{array}{l}0.757 * * * \\
(.020)\end{array}$ & $\begin{array}{l}0.980 * * * \\
(.001)\end{array}$ & $\begin{array}{l}0.715 * * * \\
(.022)\end{array}$ & $\begin{array}{l}0.711 * * * \\
(.022)\end{array}$ \\
\hline MS & $\begin{array}{l}0.759 * * * \\
(.032)\end{array}$ & $\begin{array}{l}0.755^{* * * *} \\
(.032)\end{array}$ & $\begin{array}{l}0.982 * * * \\
(.002)\end{array}$ & $\begin{array}{l}0.716^{* * * *} \\
(.034)\end{array}$ & $\begin{array}{l}0.710^{* * * *} \\
(.035)\end{array}$ \\
\hline Age & & & & & \\
\hline $25-35$ & $\begin{array}{l}0.545^{* * * *} \\
(.018)\end{array}$ & $\begin{array}{l}0.554 * * * \\
(.019)\end{array}$ & $\begin{array}{l}0.924 * * * \\
(.002)\end{array}$ & $\begin{array}{l}0.477 * * * \\
(.021)\end{array}$ & $\begin{array}{l}0.487 * * * \\
(.022)\end{array}$ \\
\hline $35-45$ & $\begin{array}{l}0.449 * * * \\
(.021)\end{array}$ & $\begin{array}{l}0.455^{* * * *} \\
(.022)\end{array}$ & $\begin{array}{l}0.911 * * * \\
(.002)\end{array}$ & $\begin{array}{l}0.379 * * * \\
(.024)\end{array}$ & $\begin{array}{l}0.385 * * * \\
(.025)\end{array}$ \\
\hline $45-55$ & $\begin{array}{l}0.456 * * * \\
(.022)\end{array}$ & $\begin{array}{l}0.458 * * * \\
(.022)\end{array}$ & $\begin{array}{l}0.912 * * * \\
(.002)\end{array}$ & $\begin{array}{l}0.382 * * * \\
(.024)\end{array}$ & $\begin{array}{l}0.383 * * * \\
(.025)\end{array}$ \\
\hline $55-$ & $\begin{array}{l}0.606 * * * \\
(.024)\end{array}$ & $\begin{array}{l}0.609 * * * \\
(.024)\end{array}$ & $\begin{array}{l}0.929 * * * \\
(.002)\end{array}$ & $\begin{array}{l}0.511 * * * \\
(.027)\end{array}$ & $\begin{array}{l}0.513 * * * \\
(.028)\end{array}$ \\
\hline TIME FE & 60 & 60 & 60 & 60 & 60 \\
\hline STATE FE & 50 & 50 & 50 & 50 & 50 \\
\hline Obs & 1648779 & 1637967 & 1648779 & 1648779 & 1637967 \\
\hline
\end{tabular}

Note: We use SIPP monthly data from panel 2008 (2008-2013) for this estimation. The dependent variable is the hazard rate from employment to unemployment. We use five specifications. The first (1) is the proportional hazard (PH) rate model with Weibull distribution as the baseline hazard. The second (2) is the IV of (1) with marginal tax rate as the instrument for homeownership. The third (3) uses OLS to estimate the hazard rate with a conditional regression, where whether the person is unemployed or not is the dependent variable and the time length that the person has already been employed is one of the independent variables. The fourth (4) is the logit form of (3). The fifth (5) is the IV of (4) with tax rate as the instrument for home-ownership. Coefficients smaller than one indicate that people are less likely to leave employment with the increase of the right hand side variables. Standard errors are clustered at the individual level and are in parentheses. Significance level: *** $\mathrm{p}<0.01, * * \mathrm{p}<0.05, * \mathrm{p}<0.1$ 
Table 12.1: The impact of home-ownership on employment spell length

\begin{tabular}{|c|c|c|c|c|}
\hline Employment spell length & (1) OLS & (2) AFT & (3) OLS- IV & (4) AFT-IV \\
\hline Home-ownership & $\begin{array}{l}1.677 * * * \\
(.093)\end{array}$ & $\begin{array}{l}0.143 * * * \\
(.014)\end{array}$ & $\begin{array}{l}0.580 * * * \\
(.148)\end{array}$ & $\begin{array}{l}0.045^{* *} \\
(.022)\end{array}$ \\
\hline \multirow{2}{*}{$\begin{array}{l}\text { State home-ownership rates } \\
65 \%-70 \%\end{array}$} & & & & \\
\hline & $\begin{array}{l}0.328 * * \\
(.160)\end{array}$ & $\begin{array}{l}0.077 * * * \\
(.026)\end{array}$ & $\begin{array}{l}0.329 * * \\
(.159)\end{array}$ & $\begin{array}{l}0.081 * * * \\
(.026)\end{array}$ \\
\hline $70 \%-$ & $\begin{array}{l}-0.147 \\
(.214)\end{array}$ & $\begin{array}{l}0.100 * * * \\
(.038)\end{array}$ & $\begin{array}{l}-0.12 \\
(.219)\end{array}$ & $\begin{array}{l}0.107 * * * \\
(.039)\end{array}$ \\
\hline Married & $\begin{array}{l}1.234 * * * \\
(.098)\end{array}$ & $\begin{array}{l}0.204 * * * \\
(.017)\end{array}$ & $\begin{array}{l}1.341 * * * \\
(.105)\end{array}$ & $\begin{array}{l}0.208 * * * \\
(.018)\end{array}$ \\
\hline Metro & $\begin{array}{l}-0.028 \\
(.118)\end{array}$ & $\begin{array}{l}0.005 \\
(.019)\end{array}$ & $\begin{array}{l}0.005 \\
(.121)\end{array}$ & $\begin{array}{l}0.011 \\
(.020)\end{array}$ \\
\hline Children number & $\begin{array}{l}-0.267 * * * \\
(.040)\end{array}$ & $\begin{array}{l}-0.053 * * * \\
(.006)\end{array}$ & $\begin{array}{l}-0.276^{* * * *} \\
(.041)\end{array}$ & $\begin{array}{l}-0.049 * * * \\
(.006)\end{array}$ \\
\hline Male & $\begin{array}{l}0.608 * * * \\
(.086)\end{array}$ & $\begin{array}{l}0.068 * * * \\
(.014)\end{array}$ & $\begin{array}{l}0.630 * * * \\
(.088)\end{array}$ & $\begin{array}{l}0.069 * * * \\
(.015)\end{array}$ \\
\hline Black & $\begin{array}{l}0.039 \\
(.138)\end{array}$ & $\begin{array}{l}0.068 * * * \\
(.022)\end{array}$ & $\begin{array}{l}0.003 \\
(.149)\end{array}$ & $\begin{array}{l}0.065 * * * \\
(.025)\end{array}$ \\
\hline Asian & $\begin{array}{l}0.089 \\
(.204)\end{array}$ & $\begin{array}{l}0.173 * * * \\
(.038)\end{array}$ & $\begin{array}{l}0.052 \\
(.209)\end{array}$ & $\begin{array}{l}0.180 * * * \\
(.039)\end{array}$ \\
\hline Latino & $\begin{array}{l}-0.602 * * \\
(.240)\end{array}$ & $\begin{array}{l}-0.056 \\
(.035)\end{array}$ & $\begin{array}{l}-0.634 * * \\
(.246)\end{array}$ & $\begin{array}{l}-0.057 \\
(.036)\end{array}$ \\
\hline BS & $\begin{array}{l}1.385^{* * * *} \\
(.108)\end{array}$ & $\begin{array}{l}0.288 * * * \\
(.021)\end{array}$ & $\begin{array}{l}1.511 * * * \\
(.111)\end{array}$ & $\begin{array}{l}0.291 * * * \\
(.021)\end{array}$ \\
\hline MS & $\begin{array}{l}1.537 * * * \\
(.143)\end{array}$ & $\begin{array}{l}0.288 * * * \\
(.033)\end{array}$ & $\begin{array}{l}1.660 * * * \\
(.147)\end{array}$ & $\begin{array}{l}0.295 * * * \\
(.034)\end{array}$ \\
\hline \multicolumn{5}{|l|}{ Age } \\
\hline $25-35$ & $\begin{array}{l}6.086^{* * * *} \\
(.134)\end{array}$ & $\begin{array}{l}0.635 * * * \\
(.019)\end{array}$ & $\begin{array}{l}6.204 * * * \\
(.142)\end{array}$ & $\begin{array}{l}0.619 * * * \\
(.020)\end{array}$ \\
\hline $35-45$ & $\begin{array}{l}8.274 * * * \\
(.141)\end{array}$ & $\begin{array}{l}0.839 * * * \\
(.022)\end{array}$ & $\begin{array}{l}8.462 * * * \\
(.144)\end{array}$ & $\begin{array}{l}0.826 * * * \\
(.023)\end{array}$ \\
\hline $45-55$ & $\begin{array}{l}8.567 * * * \\
(.142)\end{array}$ & $\begin{array}{l}0.821 * * * \\
(.023)\end{array}$ & $\begin{array}{l}8.843 * * * \\
(.144)\end{array}$ & $\begin{array}{l}0.818 * * * \\
(.024)\end{array}$ \\
\hline $55-$ & $\begin{array}{l}8.500 * * * \\
(.161)\end{array}$ & $\begin{array}{l}0.525 * * * \\
(.025)\end{array}$ & $\begin{array}{l}8.821 * * * \\
(.162)\end{array}$ & $\begin{array}{l}0.520 * * * \\
(.025)\end{array}$ \\
\hline TIME FE & 60 & 60 & 60 & 60 \\
\hline STATE FE & 50 & 50 & 50 & 50 \\
\hline Obs & 1704276 & 1648779 & 1696590 & 1637967 \\
\hline
\end{tabular}

Note: We use SIPP monthly data from panel 2008 (2008-2013) for this estimation. The dependent variable is the employment spell length. We use four specifications. The first (1) is the OLS with the employment spell length as the dependent variable. The second (2) is the accelerated failure-time (AFT) model with the employment length as the dependent variable. AFT is the same as PH in Table 12 except that PH uses the hazard rate as the dependent variable and AFT uses the employment duration as the dependent variable. (3) and (4) are the IVs for (1) and (2) with marginal tax rate as the instrument for home-ownership. Positive coefficients indicate longer employment spells with the increase of right hand side variables. Standard errors are clustered at the individual level and are in parentheses. Significance level: *** $\mathrm{p}<0.01, * * \mathrm{p}<0.05, * \mathrm{p}<0.1$ 
Table 14: The impact of home-ownership on mobility for heads with PSID data

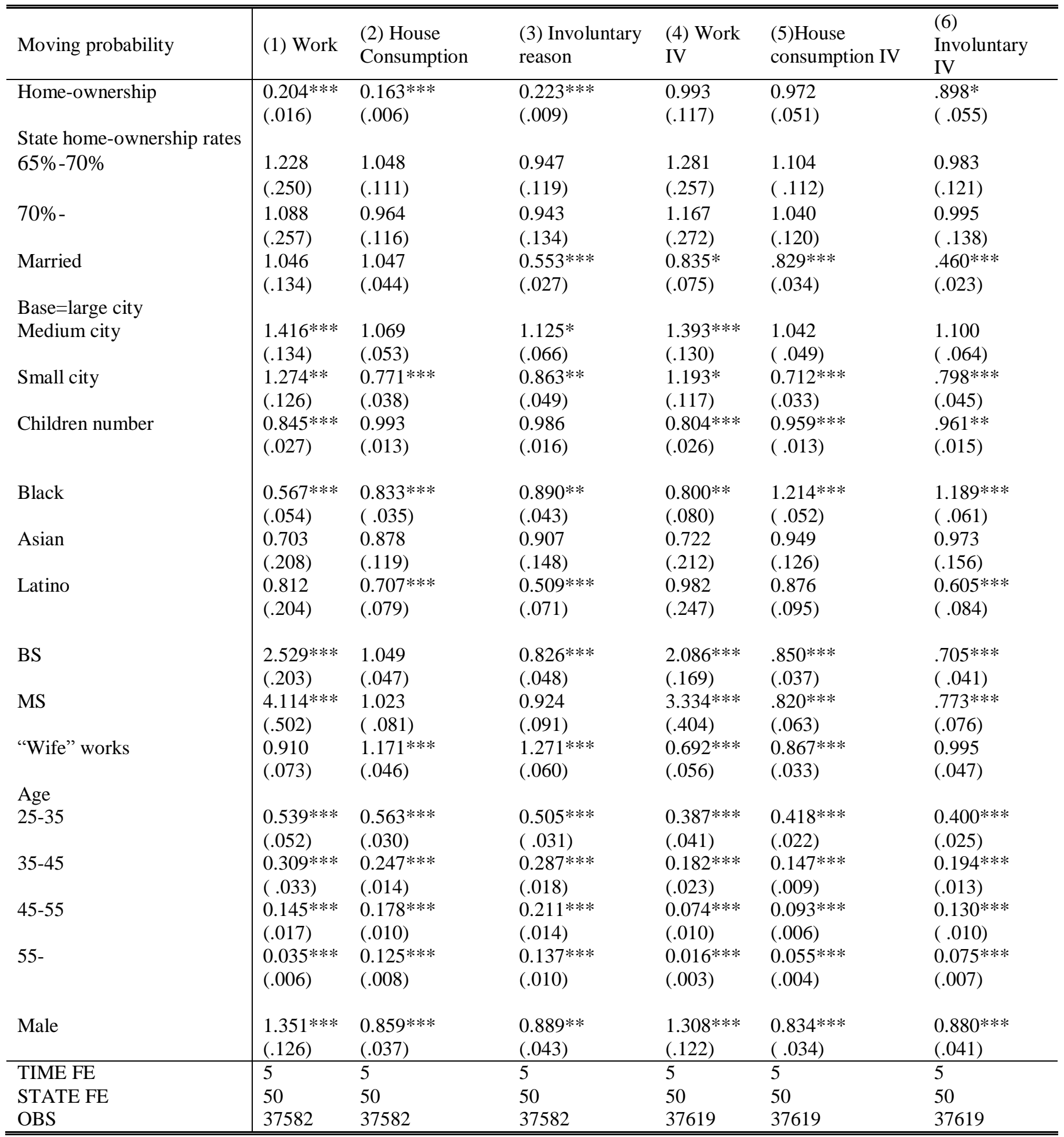

Note: We use the annual PSID data from 2001 to 2011 for this multinomial logit estimation. The dependent variable is "move" with four categories: the base is not move; the first is the moving for job reasons in column (1); the second is the moving for changing houses in (2); the third is the moving for involuntary reasons like death, disease, or eviction in (3). (4), (5) and (6) are the IVs for (1), (2) and (3) with marginal tax rate as the instrument for home-ownership. Coefficients are odds ratios. Coefficients smaller than one indicate that people are less likely to move with the increase of right hand side variables compared to not move. Standard errors are clustered at the individual level and are in parentheses. Significance level: *** $\mathrm{p}<0.01, * * \mathrm{p}<0.05, * \mathrm{p}<0.1$ 
Table 14.1: The impact of home-ownership on mobility with SIPP data

\begin{tabular}{|c|c|c|c|c|c|c|}
\hline Moving probability & $\begin{array}{l}\text { (1) Moved, } \\
\text { same county }\end{array}$ & $\begin{array}{l}\text { (2) Moved, different } \\
\text { county within same } \\
\text { state }\end{array}$ & $\begin{array}{l}\text { (3) Moved, } \\
\text { different state }\end{array}$ & (4) IV & (5) IV & (6) IV \\
\hline Home-ownership & $\begin{array}{l}.250 * * * \\
(.003)\end{array}$ & $\begin{array}{l}.293 * * * \\
(.006)\end{array}$ & $\begin{array}{l}.260 * * * \\
(.007)\end{array}$ & $\begin{array}{l}1.031 * * * \\
(.019)\end{array}$ & $\begin{array}{l}1.377 * * * \\
(.047)\end{array}$ & $\begin{array}{l}1.283 * * * \\
(.056)\end{array}$ \\
\hline State home-ownership rates & & & & & & \\
\hline $65 \%-70 \%$ & $\begin{array}{l}0.998 \\
(.015)\end{array}$ & $\begin{array}{l}1.224 * * * \\
(.033)\end{array}$ & $\begin{array}{l}1.244 * * * \\
(.042)\end{array}$ & $\begin{array}{l}.864 * * * \\
(.013)\end{array}$ & $\begin{array}{l}0.997 \\
(.028)\end{array}$ & $\begin{array}{l}1.023 \\
(.036)\end{array}$ \\
\hline $70 \%-$ & $\begin{array}{l}1.023 \\
(.017)\end{array}$ & $\begin{array}{l}1.226 * * * \\
(.036)\end{array}$ & $\begin{array}{l}1.293 * * * \\
(.049)\end{array}$ & $\begin{array}{l}.842 * * * \\
(.014)\end{array}$ & $\begin{array}{l}.919 * * * \\
(.029)\end{array}$ & $\begin{array}{l}1.002 \\
(.039)\end{array}$ \\
\hline Married & $\begin{array}{l}.838^{* * * *} \\
(.012)\end{array}$ & $\begin{array}{l}0.796 * * * \\
(.019)\end{array}$ & $\begin{array}{l}1.013 \\
(.031)\end{array}$ & $\begin{array}{l}.663 * * * \\
(.010)\end{array}$ & $\begin{array}{l}.593^{* * * *} \\
(.015)\end{array}$ & $\begin{array}{l}.765^{* * * *} \\
(.026)\end{array}$ \\
\hline Metro & $\begin{array}{l}.992 * * * \\
(.016)\end{array}$ & $\begin{array}{l}1.168 * * * \\
(.032)\end{array}$ & $\begin{array}{l}.924 * * \\
(.035)\end{array}$ & $\begin{array}{l}.966^{* *} \\
(.015)\end{array}$ & $\begin{array}{l}1.135^{* * *} \\
(.030)\end{array}$ & $\begin{array}{l}.906 * * * \\
(.034)\end{array}$ \\
\hline Children number & $\begin{array}{l}.968 * * * \\
(.005)\end{array}$ & $\begin{array}{l}.855^{* * * *} \\
(.009)\end{array}$ & $\begin{array}{l}0.990 \\
(.012)\end{array}$ & $\begin{array}{l}.964 * * * \\
(.005)\end{array}$ & $\begin{array}{l}.840 * * * \\
(.009)\end{array}$ & $\begin{array}{l}.970 * * \\
(.012)\end{array}$ \\
\hline Male & $\begin{array}{l}.935^{* * *} \\
(.011)\end{array}$ & $\begin{array}{l}0.985 \\
(.020)\end{array}$ & $\begin{array}{l}1.141^{* * *} \\
(.030)\end{array}$ & $\begin{array}{l}.938 * * * \\
(.011)\end{array}$ & $\begin{array}{l}0.999 \\
(.021)\end{array}$ & $\begin{array}{l}1.177 * * * \\
(.031)\end{array}$ \\
\hline Black & $\begin{array}{l}.952 * * * \\
(.016)\end{array}$ & $\begin{array}{l}.810^{* * *} \\
(.026)\end{array}$ & $\begin{array}{l}.826 * * * \\
(.036)\end{array}$ & $\begin{array}{l}1.193^{* * * *} \\
(.023)\end{array}$ & $\begin{array}{l}1.125^{* * * *} \\
(.039)\end{array}$ & $\begin{array}{l}1.135 * * * \\
(.052)\end{array}$ \\
\hline Asian & $\begin{array}{l}0.809 * * * \\
(.025)\end{array}$ & $\begin{array}{l}0.683 * * * \\
(.039)\end{array}$ & $\begin{array}{l}1.108^{*} \\
(.061)\end{array}$ & $\begin{array}{l}.897 * * * \\
(.027)\end{array}$ & $\begin{array}{l}0.782 * * * \\
(.044)\end{array}$ & $\begin{array}{l}1.258 * * * \\
(.068)\end{array}$ \\
\hline Latino & $\begin{array}{l}1.133 * * * \\
(.031)\end{array}$ & $\begin{array}{l}0.925 \\
(.049)\end{array}$ & $\begin{array}{l}1.049 \\
(.071)\end{array}$ & $\begin{array}{l}1.267 * * * \\
(.036)\end{array}$ & $\begin{array}{l}1.129 * * * \\
(.060)\end{array}$ & $\begin{array}{l}1.237 * * * \\
(.085)\end{array}$ \\
\hline BS & $\begin{array}{l}0.964 * * \\
(.015)\end{array}$ & $\begin{array}{l}1.286^{* * *} \\
(.034)\end{array}$ & $\begin{array}{l}1.957 * * * \\
(.062)\end{array}$ & $\begin{array}{l}0.851 * * * \\
(.011)\end{array}$ & $\begin{array}{l}1.138 * * * \\
(.030)\end{array}$ & $\begin{array}{l}1.703^{* * *} \\
(.054)\end{array}$ \\
\hline MS & $\begin{array}{l}.919 * * * \\
(.022)\end{array}$ & $\begin{array}{l}1.347 * * * \\
(.051)\end{array}$ & $\begin{array}{l}2.675^{* * * *} \\
(.107)\end{array}$ & $\begin{array}{l}.788 * * * \\
(.019)\end{array}$ & $\begin{array}{l}1.149 * * * \\
(.046)\end{array}$ & $\begin{array}{l}2.263^{* * * *} \\
(.090)\end{array}$ \\
\hline Age & & & & & & \\
\hline $25-35$ & $\begin{array}{l}.967 * * \\
(.015)\end{array}$ & $\begin{array}{l}.919 * * * \\
(.025)\end{array}$ & $\begin{array}{l}.797 * * * \\
(.030)\end{array}$ & $\begin{array}{l}1.170 * * * \\
(.020)\end{array}$ & $\begin{array}{l}1.152 * * * \\
(.035)\end{array}$ & $\begin{array}{l}1.012 \\
(.040)\end{array}$ \\
\hline $35-45$ & $\begin{array}{l}.686^{* * *} \\
(.012)\end{array}$ & $\begin{array}{l}.589 * * * \\
(.019)\end{array}$ & $\begin{array}{l}.564 * * * \\
(.023)\end{array}$ & $\begin{array}{l}0.695 * * * \\
(.013)\end{array}$ & $\begin{array}{l}0.607 * * * \\
(.020)\end{array}$ & $\begin{array}{l}0.573 * * * \\
(.024)\end{array}$ \\
\hline $45-55$ & $\begin{array}{l}.464^{* * *} \\
(.009)\end{array}$ & $\begin{array}{l}.368^{* * * *} \\
(.013)\end{array}$ & $\begin{array}{l}.378^{* * *} \\
(.018)\end{array}$ & $\begin{array}{l}.403 * * * \\
(.008)\end{array}$ & $\begin{array}{l}.317^{* * * *} \\
(.011)\end{array}$ & $\begin{array}{l}.323^{* * * *} \\
(.015)\end{array}$ \\
\hline $55-$ & $\begin{array}{l}.329 * * * \\
(.009)\end{array}$ & $\begin{array}{l}.255^{* * * *} \\
(.012)\end{array}$ & $\begin{array}{l}.323^{* * * *} \\
(.019)\end{array}$ & $\begin{array}{l}.266 * * * \\
(.007)\end{array}$ & $\begin{array}{l}.207 * * * \\
(.010)\end{array}$ & $\begin{array}{l}.251^{* * * *} \\
(.014)\end{array}$ \\
\hline TIME FE & 60 & 60 & 60 & 60 & 60 & 60 \\
\hline STATE FE & - & - & - & - & - & - \\
\hline OBS & 1704276 & 1704276 & 1704276 & 1696590 & 1696590 & 1696590 \\
\hline
\end{tabular}

Note: We use the monthly SIPP data of panel 2008 for this multinomial logit estimation. The dependent variable is "move" with four categories: the base is not move; the first is the moving within the same county in column (1); the second is the moving to different counties but within the same state in (2); the third is the moving to different states in (3). (4), (5) and (6) are the IVs for (1), (2) and (3) with marginal tax rate as the instrument for home-ownership. Coefficients are odds ratios. Coefficients smaller than one indicate that people are less likely to move with the increase of right hand side variables compared to not move. Standard errors are clustered at the individual level and are in parentheses. Significance level: *** $\mathrm{p}<0.01, * * \mathrm{p}<0.05,{ }^{*} \mathrm{p}<0.1$ 
Table 15: The impact of home-ownership on mobility for "wives" with PSID data

\begin{tabular}{|c|c|c|c|c|c|c|}
\hline Moving probability & (1) Work & $\begin{array}{l}\text { (2) House } \\
\text { Consumption }\end{array}$ & $\begin{array}{l}\text { (3) Involuntary } \\
\text { reason }\end{array}$ & $\begin{array}{l}\text { (4) Work } \\
\text { IV }\end{array}$ & $\begin{array}{l}\text { (5) House } \\
\text { consumption IV }\end{array}$ & $\begin{array}{l}(6) \\
\text { Involuntary } \\
\text { IV }\end{array}$ \\
\hline Home-ownership & $\begin{array}{l}0.184 * * * \\
(.019)\end{array}$ & $\begin{array}{l}0.134 * * * \\
(.007)\end{array}$ & $\begin{array}{l}0.169^{* * *} \\
(.012)\end{array}$ & $\begin{array}{l}0.651^{* *} \\
(.126)\end{array}$ & $\begin{array}{l}1.006 \\
(.088)\end{array}$ & $\begin{array}{l}.830^{*} \\
(.101)\end{array}$ \\
\hline $\begin{array}{l}\text { State home-ownership rates } \\
65 \%-70 \%\end{array}$ & 1.194 & 1.017 & 0.845 & 1.238 & 1.071 & 0.886 \\
\hline & $(.315)$ & $(.156)$ & $(.174)$ & $(.322)$ & $(.155)$ & $(.178)$ \\
\hline $70 \%-$ & $\begin{array}{l}1.029 \\
(.319)\end{array}$ & $\begin{array}{l}0.924 \\
(.161)\end{array}$ & $\begin{array}{l}0.990 \\
(.231)\end{array}$ & $\begin{array}{l}1.089 \\
(.333)\end{array}$ & $\begin{array}{l}1.000 \\
(.165)\end{array}$ & $\begin{array}{l}1.048 \\
(.240)\end{array}$ \\
\hline Married & $\begin{array}{l}1.163 \\
(.172)\end{array}$ & $\begin{array}{l}1.079 \\
(.071)\end{array}$ & $\begin{array}{l}0.701 * * * \\
(.056)\end{array}$ & $\begin{array}{l}0.974 \\
(.150)\end{array}$ & $\begin{array}{l}0.764 * * * \\
(.050)\end{array}$ & $\begin{array}{l}0.563 * * * \\
(.047)\end{array}$ \\
\hline Base $=$ large city & & & & & & \\
\hline Medium city & $\begin{array}{l}1.326 * * \\
(.170)\end{array}$ & $\begin{array}{l}1.010 \\
(.070)\end{array}$ & $\begin{array}{l}1.163 \\
(.107)\end{array}$ & $\begin{array}{l}1.322 * * \\
(.169)\end{array}$ & $\begin{array}{l}0.981 \\
(.065)\end{array}$ & $\begin{array}{l}1.141 \\
(.103)\end{array}$ \\
\hline Small city & $\begin{array}{l}0.987 \\
(.133)\end{array}$ & $\begin{array}{l}0.738 * * * \\
(.052)\end{array}$ & $\begin{array}{l}0.691 * * * \\
(.066)\end{array}$ & $\begin{array}{l}1.021 \\
(.136)\end{array}$ & $\begin{array}{l}0.742 * * * \\
(.049)\end{array}$ & $\begin{array}{l}0.681 * * * \\
(.064)\end{array}$ \\
\hline Children number & $\begin{array}{l}0.943 \\
(.040)\end{array}$ & $\begin{array}{l}0.955^{* *} \\
(.020)\end{array}$ & $\begin{array}{l}0.967 \\
(.028)\end{array}$ & $\begin{array}{l}0.921^{*} \\
(.039)\end{array}$ & $\begin{array}{l}.939 * * * \\
(.018)\end{array}$ & $\begin{array}{l}0.958 \\
(.027)\end{array}$ \\
\hline Black & $\begin{array}{l}0.395 * * * \\
(.063)\end{array}$ & $\begin{array}{l}0.900 \\
(.060)\end{array}$ & $\begin{array}{l}0.914 \\
(.081)\end{array}$ & $\begin{array}{l}0.489 * * * \\
(.081)\end{array}$ & $\begin{array}{l}1.395 * * * \\
(.091)\end{array}$ & $\begin{array}{l}1.258 * * * \\
(.113)\end{array}$ \\
\hline Asian & $\begin{array}{l}0.895 \\
(.295)\end{array}$ & $\begin{array}{l}0.987 \\
(.168)\end{array}$ & $\begin{array}{l}0.906 \\
(.214)\end{array}$ & $\begin{array}{l}0.926 \\
(.300)\end{array}$ & $\begin{array}{l}1.108 \\
(.180)\end{array}$ & $\begin{array}{l}1.013 \\
(.236)\end{array}$ \\
\hline Latino & $\begin{array}{l}0.521 * * \\
(.172)\end{array}$ & $\begin{array}{l}0.717 * * \\
(.101)\end{array}$ & $\begin{array}{l}0.485^{* * *} \\
(.098)\end{array}$ & $\begin{array}{l}0.587 \\
(.196)\end{array}$ & $\begin{array}{l}0.974 \\
(.133)\end{array}$ & $\begin{array}{l}0.609 \\
(.123)\end{array}$ \\
\hline BS & $\begin{array}{l}1.922 * * * \\
(.215)\end{array}$ & $\begin{array}{l}1.224 * * * \\
(.074)\end{array}$ & $\begin{array}{l}0.910 \\
(.081)\end{array}$ & $\begin{array}{l}1.689 * * * \\
(.187)\end{array}$ & $\begin{array}{l}0.973 \\
(.056)\end{array}$ & $\begin{array}{l}0.758 * * * \\
(.067)\end{array}$ \\
\hline MS & $\begin{array}{l}2.886^{* * * *} \\
(.464)\end{array}$ & $\begin{array}{l}1.290 * * * \\
(.128)\end{array}$ & $\begin{array}{l}0.877 \\
(.137)\end{array}$ & $\begin{array}{l}2.451 * * * \\
(.388)\end{array}$ & $\begin{array}{l}0.947 \\
(.091)\end{array}$ & $\begin{array}{l}.698 * * \\
(.108)\end{array}$ \\
\hline "Wife" works & $\begin{array}{l}1.730^{* * * *} \\
(.347)\end{array}$ & $\begin{array}{l}1.059 \\
(.081)\end{array}$ & $\begin{array}{l}1.066 \\
(.107)\end{array}$ & $\begin{array}{l}1.695^{* * *} \\
(.336)\end{array}$ & $\begin{array}{l}0.967 \\
(.071)\end{array}$ & $\begin{array}{l}1.017 \\
(.101)\end{array}$ \\
\hline Age & & & & & & \\
\hline $25-35$ & $\begin{array}{l}0.738 * * \\
(.106)\end{array}$ & $\begin{array}{l}0.591 * * * \\
(.043)\end{array}$ & $\begin{array}{l}0.595 * * * \\
(.060)\end{array}$ & $\begin{array}{l}0.677 * * * \\
(.113)\end{array}$ & $\begin{array}{l}0.407 * * * \\
(.031)\end{array}$ & $\begin{array}{l}0.474 * * * \\
(.053)\end{array}$ \\
\hline $35-45$ & $\begin{array}{l}0.359 * * * \\
(.057)\end{array}$ & $\begin{array}{l}0.238^{* * * *} \\
(.019)\end{array}$ & $\begin{array}{l}0.352 * * * \\
(.038)\end{array}$ & $\begin{array}{l}0.286 * * * \\
(.054)\end{array}$ & $\begin{array}{l}0.128 * * * \\
(.011)\end{array}$ & $\begin{array}{l}0.242 * * * \\
(.031)\end{array}$ \\
\hline $45-55$ & $\begin{array}{l}0.229 * * * \\
(.039)\end{array}$ & $\begin{array}{l}0.157 * * * \\
(.013)\end{array}$ & $\begin{array}{l}0.286^{* * *} \\
(.032)\end{array}$ & $\begin{array}{l}0.165 * * * \\
(.033)\end{array}$ & $\begin{array}{l}0.076^{* * * *} \\
(.007)\end{array}$ & $\begin{array}{l}0.180 * * * \\
(.024)\end{array}$ \\
\hline $55-$ & $\begin{array}{l}0.075^{* * * *} \\
(.021)\end{array}$ & $\begin{array}{l}0.116^{* * *} \\
(.012)\end{array}$ & $\begin{array}{l}0.239 * * * \\
(.034)\end{array}$ & $\begin{array}{l}0.048^{* * * *} \\
(.015)\end{array}$ & $\begin{array}{l}0.048 * * * \\
(.005)\end{array}$ & $\begin{array}{l}0.132 * * * \\
(.021)\end{array}$ \\
\hline Male & $\begin{array}{l}0.000 \\
(.000)\end{array}$ & $\begin{array}{l}0.725 \\
(.456)\end{array}$ & $\begin{array}{l}1.730 \\
(.968)\end{array}$ & $\begin{array}{l}0.000 \\
(.000)\end{array}$ & $\begin{array}{l}0.916 \\
(.545)\end{array}$ & $\begin{array}{l}1.933 \\
(1.044)\end{array}$ \\
\hline TIME FE & 5 & 5 & 5 & 5 & 5 & 5 \\
\hline STATE FE & 50 & 50 & 50 & 50 & 50 & 50 \\
\hline OBS & 20962 & 20962 & 20962 & 20962 & 20962 & 20962 \\
\hline
\end{tabular}

Note: We use the annual PSID data from 2001 to 2011 for this multinomial logit estimation. The dependent variable is "move" with four categories: the base is not move; the first is the moving for job reasons in column (1); the second is the moving for changing a house in (2); the third is the moving for involuntary reasons like death, disease, or eviction in (3). (4), (5) and (6) are the IVs for (1), (2) and (3) with marginal tax rate as the instrument for home-ownership. Coefficients are odds ratios. Coefficients smaller than one indicate that people are less likely to move with the increase of right hand side variables compared to not move. Standard errors are clustered at the individual level and are in parentheses. Significance level: $* * * \mathrm{p}<0.01, * * \mathrm{p}<0.05, * \mathrm{p}<0.1$ 
Table 16: The impact of home-ownership on wages for heads

\begin{tabular}{|c|c|c|c|}
\hline $\log ($ wage $)$ & (1) OLS & (2)OLS-IV & (3)FE \\
\hline Home-ownership & $\begin{array}{l}.342 * * * \\
(.012)\end{array}$ & $\begin{array}{l}.000 \\
(.016)\end{array}$ & $\begin{array}{l}.063 * * * \\
(.011)\end{array}$ \\
\hline State home-ownership rates & & & \\
\hline $65 \%-70 \%$ & $\begin{array}{l}.036^{*} \\
(.019)\end{array}$ & $\begin{array}{l}.035^{*} \\
(.019)\end{array}$ & $\begin{array}{l}.028 * \\
(.015)\end{array}$ \\
\hline $70 \%-$ & $\begin{array}{l}.018 \\
(.023)\end{array}$ & $\begin{array}{l}.018 \\
(.023)\end{array}$ & $\begin{array}{l}.020 \\
(.019)\end{array}$ \\
\hline Married & $\begin{array}{l}.218^{* * * *} \\
(.015)\end{array}$ & $\begin{array}{l}.274 * * * \\
(.016)\end{array}$ & $\begin{array}{l}- \\
(-)\end{array}$ \\
\hline Children number & $\begin{array}{l}-.020 * * * \\
(.015)\end{array}$ & $\begin{array}{l}-.009 * \\
(.005)\end{array}$ & $\begin{array}{l}.008^{*} \\
(.004)\end{array}$ \\
\hline Male & $\begin{array}{l}.223 * * * \\
(.016)\end{array}$ & $\begin{array}{l}.262 * * * \\
(.017)\end{array}$ & $(-)$ \\
\hline Black & $\begin{array}{l}-.199 * * * \\
(.016)\end{array}$ & $\begin{array}{l}-.265^{* * * *} \\
(.017)\end{array}$ & $\begin{array}{l}-.007 \\
(.079)\end{array}$ \\
\hline Asian & $\begin{array}{l}.006 \\
(.060)\end{array}$ & $\begin{array}{l}-.018 \\
(.063)\end{array}$ & $\begin{array}{l}-.070 \\
(.144)\end{array}$ \\
\hline Latino & $\begin{array}{l}-.409 * * * \\
(.036)\end{array}$ & $\begin{array}{l}-.453 * * * \\
(.037)\end{array}$ & $\begin{array}{l}.004 \\
(.041)\end{array}$ \\
\hline B.S. & $\begin{array}{l}.433 * * * \\
(.016)\end{array}$ & $\begin{array}{l}.457 * * * \\
(.017)\end{array}$ & $\begin{array}{l}.063^{*} \\
(.038)\end{array}$ \\
\hline M.S. & $\begin{array}{l}.671^{* * * *} \\
(.029)\end{array}$ & $\begin{array}{l}.695 * * * \\
(.030)\end{array}$ & $\begin{array}{l}.246 * * * \\
(.050)\end{array}$ \\
\hline Age & & & \\
\hline $25-35$ & $\begin{array}{l}.252 * * * \\
(.016)\end{array}$ & $\begin{array}{l}.330 * * * \\
(.016)\end{array}$ & $\begin{array}{l}.220 * * * \\
(.017)\end{array}$ \\
\hline $35-45$ & $\begin{array}{l}.316^{* * * *} \\
(.018)\end{array}$ & $\begin{array}{l}.457 * * * \\
(.018)\end{array}$ & $\begin{array}{l}.280 * * * \\
(.024)\end{array}$ \\
\hline $45-55$ & $\begin{array}{l}.288 * * * \\
(.019)\end{array}$ & $\begin{array}{l}.468 * * * \\
(.020)\end{array}$ & $\begin{array}{l}.244 * * * \\
(.033)\end{array}$ \\
\hline $55-$ & $\begin{array}{l}.048^{*} \\
(.028)\end{array}$ & $\begin{array}{l}.245 * * * \\
(.029)\end{array}$ & $\begin{array}{l}.014 \\
(.043)\end{array}$ \\
\hline Constant & $\begin{array}{l}9.081 \text { *** } \\
(.079)\end{array}$ & $\begin{array}{l}9.140 * * * \\
(.081)\end{array}$ & 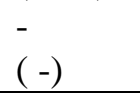 \\
\hline TIME FE & 58 & 58 & 58 \\
\hline STATE FE & 50 & 50 & 50 \\
\hline Obs & 45939 & 45939 & 45939 \\
\hline
\end{tabular}

Note: we use the monthly PSID data from 2001 to 2011 for this estimation. The dependent variable is the $\log$ (wage). We use three specifications: OLS in (1), IV for (1) in (2) and fixed effect in (3). The instrument is the state level marginal tax rate for home-ownership. Standard errors are clustered at the individual level and are in parentheses. Significance level: $* * * \mathrm{p}<0.01, * * \mathrm{p}<0.05, * \mathrm{p}<0.1$ 
Table 17: The impact of home-ownership on wages for "wives"

\begin{tabular}{|c|c|c|c|}
\hline $\log ($ wage $)$ & (1)OLS & (2)OLS-IV & (3)FE \\
\hline Home-ownership & $\begin{array}{l}.261 * * * \\
(.022)\end{array}$ & $\begin{array}{l}.053 \\
(.037)\end{array}$ & $\begin{array}{l}.059 * * * \\
(.020)\end{array}$ \\
\hline $\begin{array}{l}\text { State home-ownership rates } \\
65 \%-70 \%\end{array}$ & $\begin{array}{l}.099 \\
(.072)\end{array}$ & $\begin{array}{l}.099 \\
(.072)\end{array}$ & $\begin{array}{l}.074 \\
(.062)\end{array}$ \\
\hline $70 \%-$ & $\begin{array}{l}.094 \\
(.076)\end{array}$ & $\begin{array}{l}.096 \\
(.077)\end{array}$ & $\begin{array}{l}.061 \\
(.065)\end{array}$ \\
\hline Married & $\begin{array}{l}-.015 \\
(.027)\end{array}$ & $\begin{array}{l}.012 \\
(.029)\end{array}$ & $\overline{(-)}$ \\
\hline Children number & $\begin{array}{l}-.110 * * * \\
(.009)\end{array}$ & $\begin{array}{l}-.106 * * * \\
(.009)\end{array}$ & $\begin{array}{l}-.053 * * * \\
(.007)\end{array}$ \\
\hline Male & - & $\begin{array}{l}- \\
(-)\end{array}$ & $\begin{array}{l}- \\
(-)\end{array}$ \\
\hline Black & $\begin{array}{l}.126 * * * \\
(.027)\end{array}$ & $\begin{array}{l}.092 * * * \\
(.028)\end{array}$ & $\begin{array}{l}.111 \\
(.125)\end{array}$ \\
\hline Asian & $\begin{array}{l}.229 * * * \\
(.080)\end{array}$ & $\begin{array}{l}.221 * * * \\
(.081)\end{array}$ & $\begin{array}{l}.229 \\
(.175)\end{array}$ \\
\hline Latino & $\begin{array}{l}-.406^{* * * *} \\
(.063)\end{array}$ & $\begin{array}{l}-.439 * * * \\
(.063)\end{array}$ & $\begin{array}{l}-.192 * * * \\
(.065)\end{array}$ \\
\hline B.S. & $\begin{array}{l}.416 * * * \\
(.029)\end{array}$ & $\begin{array}{l}.426 * * * \\
(.029)\end{array}$ & $\begin{array}{l}.093^{*} \\
(.054)\end{array}$ \\
\hline M.S. & $\begin{array}{l}.687 * * * \\
(.046)\end{array}$ & $\begin{array}{l}.702 * * * \\
(.046)\end{array}$ & $\begin{array}{l}.190 * * * \\
(.070)\end{array}$ \\
\hline Age & & & \\
\hline $25-35$ & $\begin{array}{l}.209 * * * \\
(.028)\end{array}$ & $\begin{array}{l}.251 * * * \\
(.032)\end{array}$ & $\begin{array}{l}.132 * * * \\
(.030)\end{array}$ \\
\hline $35-45$ & $\begin{array}{l}.232 * * * \\
(.030)\end{array}$ & $\begin{array}{l}.305 * * * \\
(.038)\end{array}$ & $\begin{array}{l}.174 * * * \\
(.041)\end{array}$ \\
\hline $45-55$ & $\begin{array}{l}.157 * * * \\
(.031)\end{array}$ & $\begin{array}{l}.243 * * * \\
(.038)\end{array}$ & $\begin{array}{l}.146 * * * \\
(.053)\end{array}$ \\
\hline $55-$ & $\begin{array}{l}-.126 * * * \\
(.047)\end{array}$ & $\begin{array}{l}-.033 * * * \\
(.052)\end{array}$ & $\begin{array}{l}-.070 \\
(.068)\end{array}$ \\
\hline Constant & $\begin{array}{l}8.960 * * * \\
(.129)\end{array}$ & $\begin{array}{l}9.046 * * * \\
(.129)\end{array}$ & $(-)$ \\
\hline TIME FE & 58 & 58 & 58 \\
\hline STATE FE & 50 & 50 & 50 \\
\hline Obs & 22713 & 22713 & 22713 \\
\hline
\end{tabular}

Note: we use the monthly PSID data from 2001 to 2011 for this estimation. The dependent variable is the log (wage). We use three specifications: OLS in (1), IV for (1) in (2) and fixed effect in (3). The instrument is the state level marginal tax rate for home-ownership. Standard errors are clustered at the individual level and are in parentheses. Significance level: $* * * \mathrm{p}<0.01, * * \mathrm{p}<0.05, * \mathrm{p}<0.1$ 
Table 19: Mortgage's effect on owners' unemployment probability for heads

\begin{tabular}{l|ccccccc}
\hline \hline \multirow{2}{*}{ Unemployment probability for head owners } & (1) whole period & (2) IV & (3) before 2007 & (4) IV & (5) after 2007 & (6) IV \\
& & & & & & \\
\hline mortgage dummy & $-.423^{* * *}$ & -.013 & $-.436^{* * *}$ & -.194 & $-.401^{* *}$ & .036 \\
& $(.101)$ & $(.262)$ & $(.111)$ & $(.273)$ & $(.186)$ & $(.473)$ \\
Controls & & & & & & & \\
\hline TIME FE & 5 & 5 & 4 & 4 & 1 & 1 \\
STATE FE & 50 & 50 & 50 & 50 & 50 & 50 \\
OBS & 18076 & 18076 & 15037 & 15037 & 2964 & 2964 \\
\hline \hline
\end{tabular}

Note: we use the annual PSID data from 2001 to 2011 for this logit estimation. Only owners are included. The dependent variable is the probability of unemployment. The independent variable of interest is the mortgage dummy. Column (1) is for the whole period, covering 2001 to 2011. Column (2) is the IV of (1) with marginal tax rate as the instrument for mortgage dummy. Column (3) is for the period before 2007-pre-financial crisis. Column (4) is the IV for (3). Column (5) is for after 2007-post-financial crisis and (6) is the IV for (5). Controls include age, marriage, children number, sex, education, population, and race. Standard errors are clustered at the individual level and are in parentheses. Significance level: $* * * \mathrm{p}<0.01, * * \mathrm{p}<0.05, * \mathrm{p}<0.1$

Table 20: Negative equity's effect on owners' unemployment probability for heads

\begin{tabular}{l|cccccc}
\hline \hline Unemployment probability for head owners & (1) whole period & (2) IV & (3) before 2007 & (4) IV & (5) after 2007 & (6) IV \\
\hline $\log (\mid$ negative equity|) & .071 & .016 & -.014 & -.447 & .416 & 1.050 \\
& $(.140)$ & $(.186)$ & $(.244)$ & $(.801)$ & $(.326)$ & $(.810)$ \\
Controls & & & & & & \\
\hline TIME FE & 5 & 5 & 4 & 4 & 1 & 1 \\
STATE FE & 50 & 50 & 50 & 50 & 50 & 50 \\
OBS & 513 & 18076 & 248 & 15037 & 142 & 2964 \\
\hline \hline
\end{tabular}

Note: we use the annual PSID data from 2001 to 2011 for this logit estimation. Only owners are included. The dependent variable is the probability of unemployment. The independent variable of interest is the $\log$ of the absolute value of negative equity. Column (1) is for the whole period, covering 2001 to 2011. Column (2) is the IV of (1) with state level negative equity rate as the instrument for the log of the absolute value of negative equity. Column (3) is for the period before 2007-pre-financial crisis. Column (4) is the IV for (3). Column (5) is for after 2007-post-financial crisis and (6) is the IV for (5). Controls include age, marriage, children number, sex, education, population, and race. Standard errors are clustered at the individual level and are in parentheses. Significance level: $* * * \mathrm{p}<0.01, * * \mathrm{p}<0.05, * \mathrm{p}<0.1$ 
Table 21: The effects of wealth and attachment to community on unemployment probability for head owners

\begin{tabular}{|c|c|c|c|c|c|c|c|c|c|c|}
\hline \multicolumn{11}{|c|}{ Dependent variable: unemployment probability for head owners } \\
\hline \multicolumn{11}{|l|}{ Wealth } \\
\hline \multirow[t]{2}{*}{$\log$ (house value) } & $-.366 * * *$ & & & & & & & & & \\
\hline & $(.041)$ & & & & & & & & & \\
\hline \multirow[t]{2}{*}{$\log$ (positive equity) } & & $-.107 * * *$ & & & & & & & & \\
\hline & & $(.033)$ & & & & & & & & \\
\hline \multirow[t]{2}{*}{ positive equity dummy } & & & -.111 & & & & & & & \\
\hline & & & $(.143)$ & & & & & & & \\
\hline \multirow[t]{2}{*}{ wealth (excluding housing) } & & & & $-.146 * * *$ & & & & & & \\
\hline & & & & $(.028)$ & & & & & & \\
\hline \multirow[t]{2}{*}{ wealth dummy } & & & & & $-.232 *$ & & & & & \\
\hline & & & & & $(.139)$ & & & & & \\
\hline \multirow[t]{2}{*}{ wealthh (including housing) } & & & & & & $-.127 * * *$ & & & & \\
\hline & & & & & & $(.024)$ & & & & \\
\hline \multirow[t]{2}{*}{ wealthh dummy } & & & & & & & $-.442 * * *$ & & & \\
\hline & & & & & & & $(.090)$ & & & \\
\hline \multicolumn{11}{|l|}{ Attachment to community } \\
\hline \multirow[t]{2}{*}{$\log$ (improvement) } & & & & & & & & -.066 & & \\
\hline & & & & & & & & $(.085)$ & & \\
\hline \multirow{3}{*}{$\begin{array}{l}\text { improvement dummy } \\
\text { time for being homeowners }\end{array}$} & & & & & & & & \multirow{2}{*}{\multicolumn{3}{|c|}{$\begin{array}{l}-.134 \\
(.126)\end{array}$}} \\
\hline & & & & & & & & & & \\
\hline & & & & & & & & & & \\
\hline \multirow[t]{2}{*}{$5-10 \mathrm{yrs}$} & & & & & & & & & & -.124 \\
\hline & & & & & & & & & & $(.160)$ \\
\hline \multirow[t]{2}{*}{$10-\mathrm{yrs}$} & & & & & & & & & & -.179 \\
\hline & & & & & & & & & & (.179) \\
\hline \multicolumn{11}{|l|}{ Controls } \\
\hline TIME FE & 4 & 5 & 5 & 5 & 5 & 5 & 5 & 9 & 4 & 4 \\
\hline STATE FE & 50 & 50 & 50 & 50 & 50 & 50 & 50 & 50 & 50 & 50 \\
\hline OBS & 18076 & 17162 & 18076 & 17116 & 18076 & 15590 & 18076 & 29562 & 1785 & 10683 \\
\hline
\end{tabular}

Note: we use the annual PSID data from 2001 to 2011 for this logit estimation. Only owners are included. The dependent variable is the probability of unemployment. The independent variables of interest are the wealth and attachment to community. The wealth includes $\log$ of the house value, $\log$ of the positive equity value, positive equity dummy, $\log$ of the wealth value without housing and its dummy, and log of the wealth value with housing and its dummy. The dummy is whether the owner has non-negative wealth. The attachment to community includes $\log$ of the improvement value that the owner made to their property and its dummy, and the time of being homeowners. Controls include age, marriage, children number, sex, education, population, and race. Standard errors are clustered at the individual level and are in parentheses. Significance level: $* * * \mathrm{p}<0.01, * * \mathrm{p}<0.05, *$ $\mathrm{p}<0.1$ 
Table 22: Mortgage's effect on owners' hazard rates from employment to unemployment

\begin{tabular}{l|cccc}
\hline \hline $\begin{array}{l}\text { Hazard rate from employment to } \\
\text { unemployment }\end{array}$ & $\begin{array}{c}\text { (1) before } \\
2007\end{array}$ & (2) IV & $\begin{array}{c}\text { (3) after } \\
2007\end{array}$ & (4) IV \\
\hline & & & & \\
mortgage dummy & $0.977^{* * *}$ & $0.590^{* * *}$ & 0.813 & 1.113 \\
& $(.001)$ & $(.015)$ & $(.156)$ & $(.368)$ \\
Controls & & & & 56 \\
\hline TIME FE & 36 & 36 & 50 & 50 \\
STATE FE & 50 & 50 & 1198346 & 1198346 \\
OBS & 873342 & 873342 & \\
\hline \hline
\end{tabular}

Note: we use the monthly SIPP data of the 2008 panel for this PH estimation. Only owners are included. The dependent variable is the hazard rate of leaving employment. The independent variable of interest is the mortgage dummy. Column (1) is for the period before 2007-pre-financial crisis. Column (2) is the IV for (1). Column (3) is for after 2007-post-financial crisis and (4) is the IV for (3). The instrument is the state level marginal tax rate for mortgage dummy. Controls include age, marriage, children number, sex, education, population, and race. Coefficients less than one indicate that people are less likely to leave employment in the presence of mortgages. Standard errors are clustered at the individual level and are in parentheses. Significance level: $* * * \mathrm{p}<0.01, * *$ $\mathrm{p}<0.05, * \mathrm{p}<0.1$

Table 22.1 Mortgage's effect on owners' hazard rates from unemployment to employment

\begin{tabular}{l|cccc}
\hline \hline $\begin{array}{l}\text { Hazard rate from unemployment to } \\
\text { employment }\end{array}$ & $\begin{array}{c}\text { (1) before } \\
2007\end{array}$ & (2) IV & $\begin{array}{c}\text { (3) after } \\
2007\end{array}$ & (4) IV \\
\hline & & & & \\
mortgage dummy & $0.989^{* * *}$ & $0.807 * * *$ & 0.974 & 1.074 \\
& $(.000)$ & $(.007)$ & $(.017)$ & $(.142)$ \\
Controls & & & 56 & 56 \\
\hline TIME FE & 36 & 50 & 50 & 50 \\
STATE FE & 50 & 873342 & 1198346 & 1198346 \\
OBS & 873342 & & & \\
\hline \hline
\end{tabular}

Note: we use the monthly SIPP data of the 2008 panel for this PH estimation. Only owners are included. The dependent variable is the hazard rate of leaving unemployment. The independent variable of interest is the mortgage dummy. Column (1) is for the period before 2007-pre-financial crisis. Column (2) is the IV for (1). Column (3) is for after 2007-post-financial crisis and (4) is the IV for (3). The instrument is the state level marginal tax rate for mortgage dummy. Controls include age, marriage, children number, sex, education, population, and race. Coefficients less than one indicate that people are less likely to leave unemployment in the presence of mortgages. Standard errors are clustered at the individual level and are in parentheses. Significance level: *** $\mathrm{p}<0.01, * * \mathrm{p}<0.05, * \mathrm{p}<0.1$ 
Table 23: Negative equity's effect on owners' hazard rates of employment and unemployment

\begin{tabular}{|c|c|c|c|c|c|}
\hline Year & $\begin{array}{c}\text { (1) Hazard rate from employment to } \\
\text { unemployment }\end{array}$ & (2) IV & $\begin{array}{l}\text { (3) Hazard rate from unemployment to } \\
\text { employment }\end{array}$ & (4) IV & Obs \\
\hline 2003 & $\begin{array}{l}0.896 \\
(.198)\end{array}$ & $\begin{array}{c}2.604 * * * \\
(.549)\end{array}$ & $\begin{array}{c}1.043 * * \\
(.022)\end{array}$ & $\begin{array}{c}1.726 * * * \\
(.060)\end{array}$ & 46225 \\
\hline 2005 & $\begin{array}{c}1.12 \\
(.233)\end{array}$ & $\begin{array}{c}2.439 * * * \\
(.622)\end{array}$ & $\begin{array}{l}1.027 \\
(.020)\end{array}$ & $\begin{array}{c}1.667 * * * \\
(.070)\end{array}$ & 47065 \\
\hline 2007 & $\begin{array}{l}0.832 \\
(.240)\end{array}$ & $\begin{array}{l}2.993 * * * \\
(.837)\end{array}$ & $\begin{array}{l}1.091 * * * \\
(.026)\end{array}$ & $\begin{array}{l}1.8 * * * \\
(.096)\end{array}$ & 46957 \\
\hline 2009 & $\begin{array}{c}0.82 \\
(.190)\end{array}$ & $\begin{array}{c}2.587 * * * \\
(.662)\end{array}$ & $\begin{array}{c}1.094 * * * \\
(.024)\end{array}$ & $\begin{array}{c}1.726 * * * \\
(.102)\end{array}$ & 46499 \\
\hline 2011 & $\begin{array}{l}0.996 \\
(.165)\end{array}$ & $\begin{array}{l}1.564 \\
(.466)\end{array}$ & $\begin{array}{c}1.068 * * * \\
(.024)\end{array}$ & $\begin{array}{c}1.495^{* * *} \\
(.088)\end{array}$ & 40104 \\
\hline Controls & & & & & \\
\hline State FE & 50 & 50 & 50 & 50 & 50 \\
\hline Time FE & 11 & 11 & 11 & 11 & 11 \\
\hline
\end{tabular}

Note: we use the annual PSID data from 2003 to 2011 for this PH estimation. We estimate each year separately because the employment conditions are not continuous. Only owners are included. The dependent variable is the hazard rates of employment and unemployment. The independent variable of interest is the log of the absolute value of negative equity. Column (1) is the hazard rate of leaving employment. Column (2) is the IV of (1) with the state level negative equity rate as the instrument for the log of the absolute value of negative equity. Column (3) is the hazard rate of leaving unemployment. Column (4) is the IV for (3). Controls include age, marriage, children number, sex, education, population, and race. For (1) and (2), coefficients larger than one mean that people are more likely to leave employment with more negative equity. For (3) and (4), coefficients larger than one mean that people are more likely to leave unemployment with larger negative equity. Standard errors are clustered at the individual level and are in parentheses. Significance level: *** $\mathrm{p}<0.01, * * \mathrm{p}<0.05, * \mathrm{p}<0.1$ 
Table 24: The effects of wealth and attachment to community on owners' hazard rate from employment to unemployment

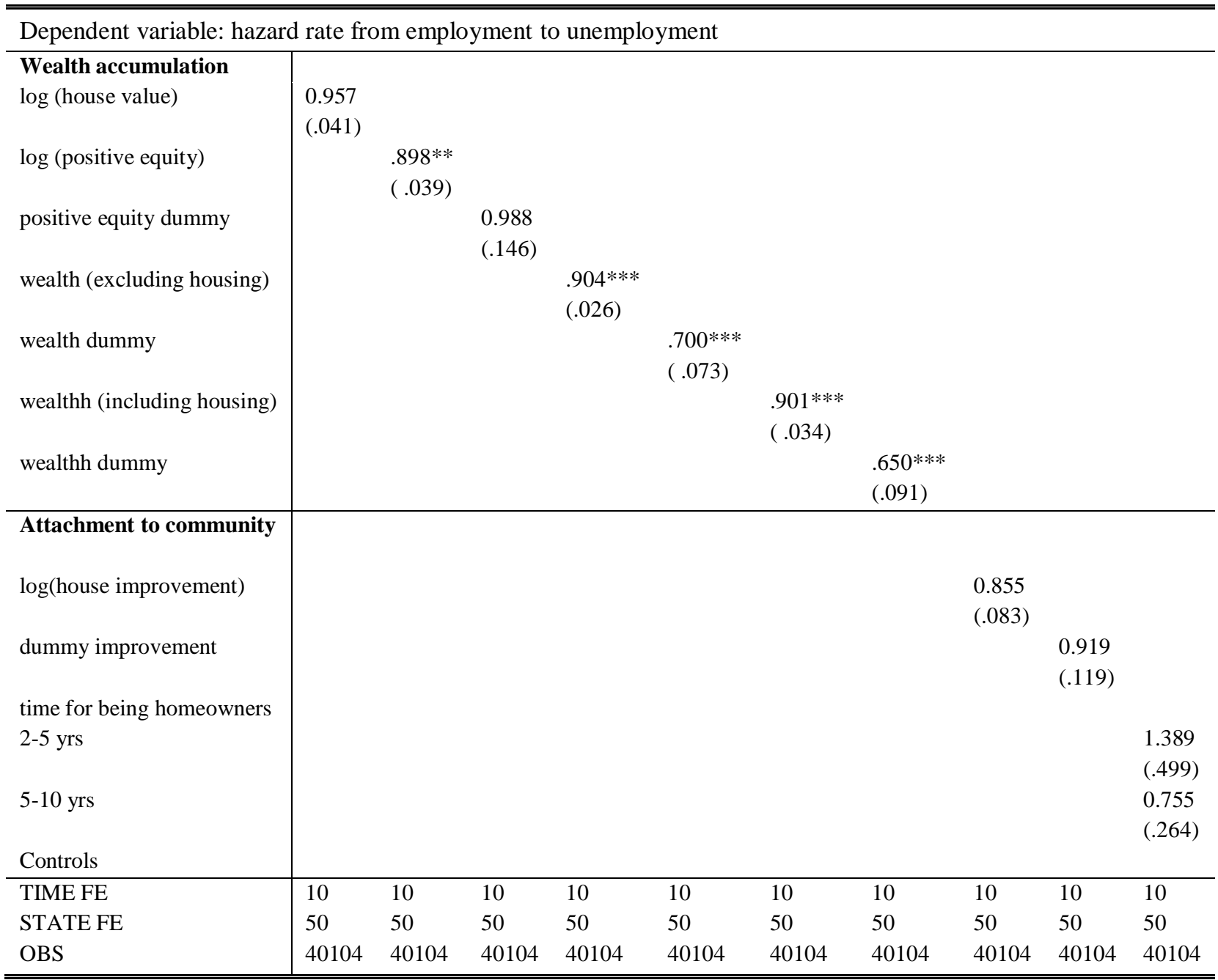

Note: we use the monthly PSID data of 2011 for this PH estimation. Only owners are included. The dependent variable is the hazard rate from employment to unemployment. The independent variables of interest are the wealth and attachment to community. The wealth includes log of the house value, log of the positive equity value, positive equity dummy, $\log$ of the wealth value without housing and its dummy, and log of the wealth value with housing and its dummy. The dummy is whether the owner has non-negative wealth or not. The attachment to community includes log of the improvement value that the owner made to their property and its dummy, and the time of being homeowners. Controls include age, marriage, children number, sex, education, population, and race. Coefficients less than one indicate that people are less likely to leave employment with the increase of right hand side variables. Standard errors are clustered at the individual level and are in parentheses. Significance level: $* * * \mathrm{p}<0.01, * *$ $\mathrm{p}<0.05, * \mathrm{p}<0.1$ 
Table 24.1: The effects of wealth and attachment to community on owners' hazard rate from unemployment to employment

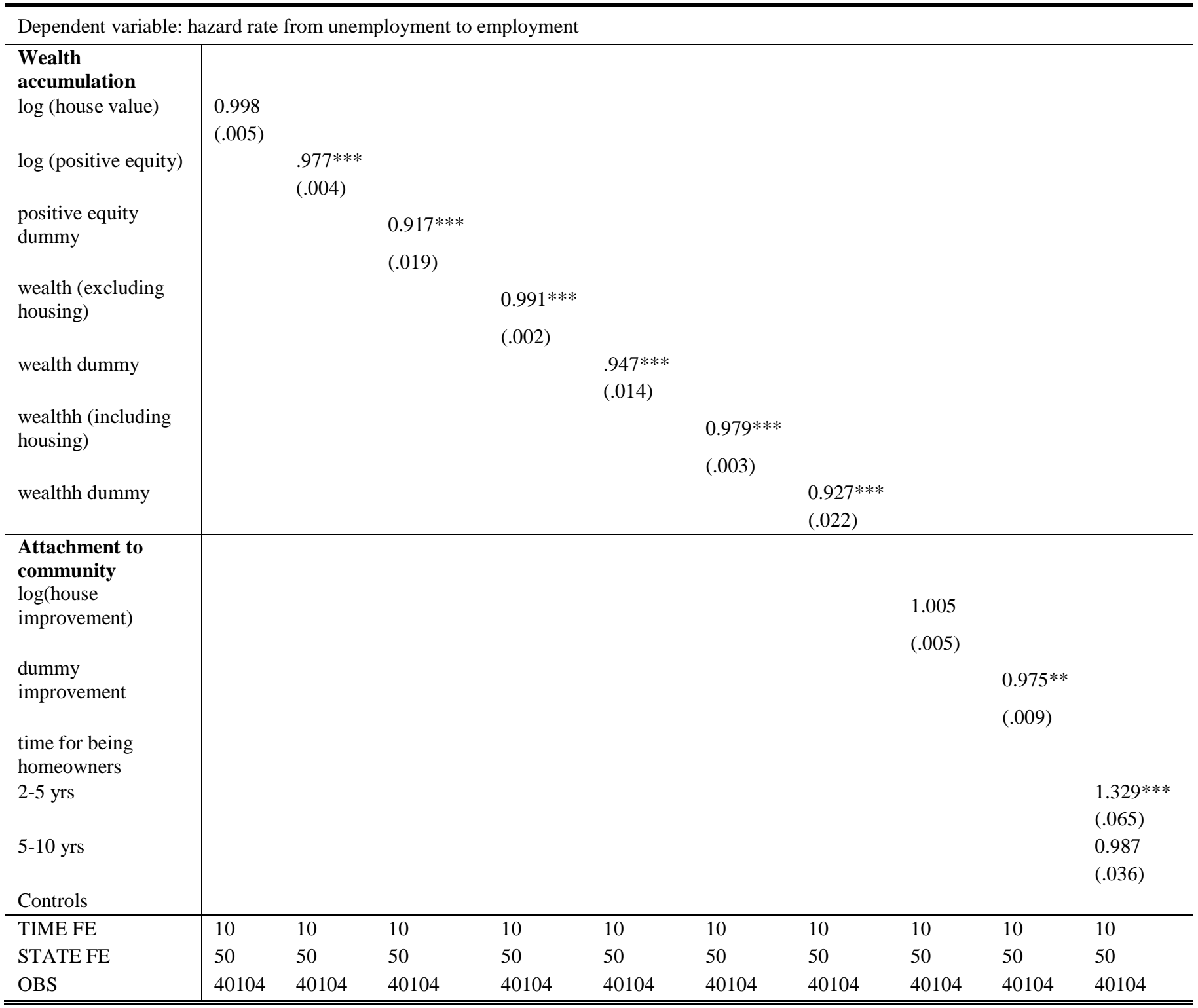

Note: we use the monthly PSID data of 2011 for this PH estimation. Only owners are included. The dependent variable is the hazard rate from unemployment to employment. The independent variables of interest are the wealth and attachment to community. The wealth includes $\log$ of the house value, $\log$ of the positive equity value, positive equity dummy, log of the wealth value without housing and its dummy, and log of the wealth value with housing and its dummy. The dummy is whether the owner has non-negative wealth or not. The attachment to community includes log of the improvement value that the owner made to their property and its dummy, and the time of being homeowners. Controls include age, marriage, children number, sex, education, population, and race. Coefficients less than one indicate that people are less likely to leave unemployment with the increase of right hand side variables. Standard errors are clustered at the individual level and are in parentheses. Significance level: $* * * \mathrm{p}<0.01$, $* * \mathrm{p}<0.05, * \mathrm{p}<0.1$ 
Table 25: Mortgage's effect on owners' mobility

\begin{tabular}{l|cccccc}
\hline \hline Moving probability & (1) whole period & (2) IV & (3) before 2007 & (4) IV & (5) after 2007 & (6) IV \\
\hline mortgage dummy & 1.205 & 1.152 & 1.166 & 1.009 & 1.572 & 1.516 \\
& $(.166)$ & $(.421)$ & $(.170)$ & $(.412)$ & $(.700)$ & $(1.318)$ \\
Controls & & & & & & \\
\hline TIME FE & 9 & 5 & 8 & 4 & 1 & 1 \\
STATE FE & 50 & 50 & 50 & 50 & 50 & 50 \\
OBS & 39100 & 23686 & 35110 & 19696 & 3990 & 3990 \\
\hline \hline
\end{tabular}

Note: we use the annual PSID data from 2001 to 2011 for this multinomial logit estimation. Only owners are included. The dependent variable is the probability of moving. The independent variable of interest is the mortgage dummy. We only report the coefficients for job moves. Column (1) is for the whole period, covering 2001 to 2011. Column (2) is the IV of (1) with marginal tax rate as the instrument for mortgage dummy. Column (3) is for the period before 2007-pre-financial crisis. Column (4) is the IV for (3). Column (5) is for after 2007-post-financial crisis and (6) is the IV for (5). Controls include age, marriage, children number, sex, education, population, and race. Coefficients larger than one mean that people are more likely to move for jobs in the presence of mortgages. Standard errors are clustered at the individual level and are in parentheses. Significance level: $* * * \mathrm{p}<0.01, * *$ $\mathrm{p}<0.05, * \mathrm{p}<0.1$

Table 26: Negative equity's effect on owners' mobility

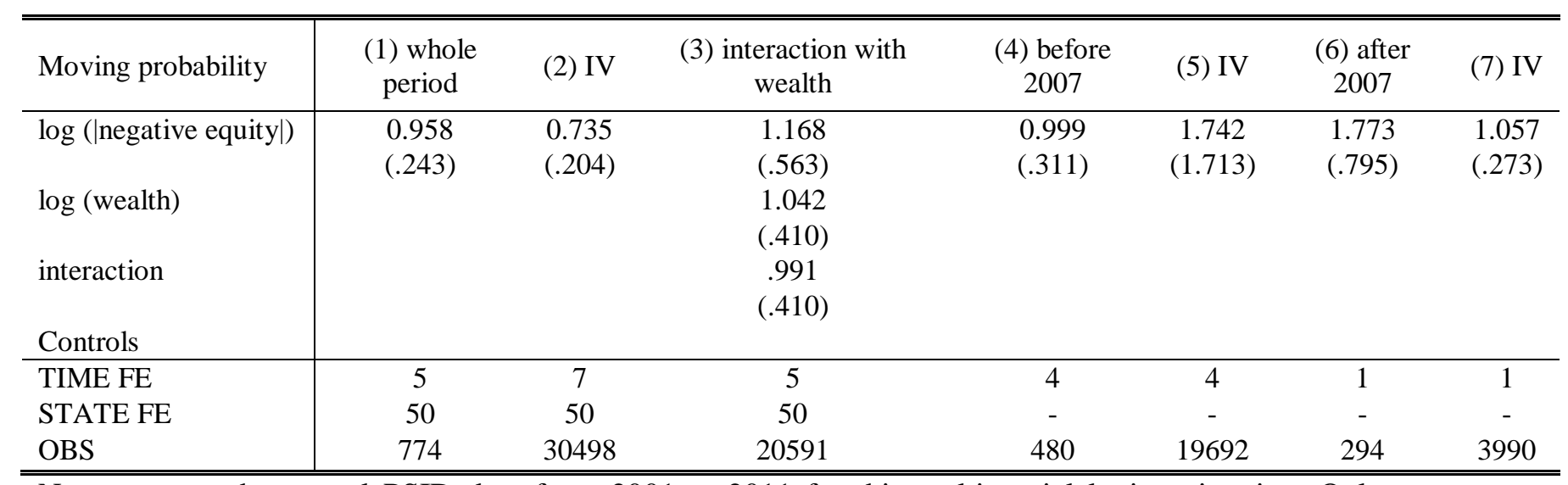

Note: we use the annual PSID data from 2001 to 2011 for this multinomial logit estimation. Only owners are included. The dependent variable is the probability of moving. The independent variables of interest are the log of the absolute value of negative equity, $\log$ of wealth and their interaction terms. We only report the coefficients for job moves. Column (1) is for the whole period, covering 2001 to 2011. Column (2) is the IV of (1) with state level negative equity rate as the instrument for the log of the absolute value of negative equity. Column (3) is for the whole period with the log wealth and their interaction terms added. Column (4) is for before 2007-pre-financial crisis. Column (5) is the IV for (4). Column (6) is for after 2007-post-financial crisis and (7) is the IV for (6). Controls include age, marriage, children number, sex, education, population, and race. Coefficients larger than one indicate that people are more likely to move for jobs with larger negative equity. Standard errors are clustered at the individual level and are in parentheses. Significance level: $* * * \mathrm{p}<0.01, * * \mathrm{p}<0.05, * \mathrm{p}<0.1$ 
Table 27: The effects of wealth and attachment to community on head owners' mobility

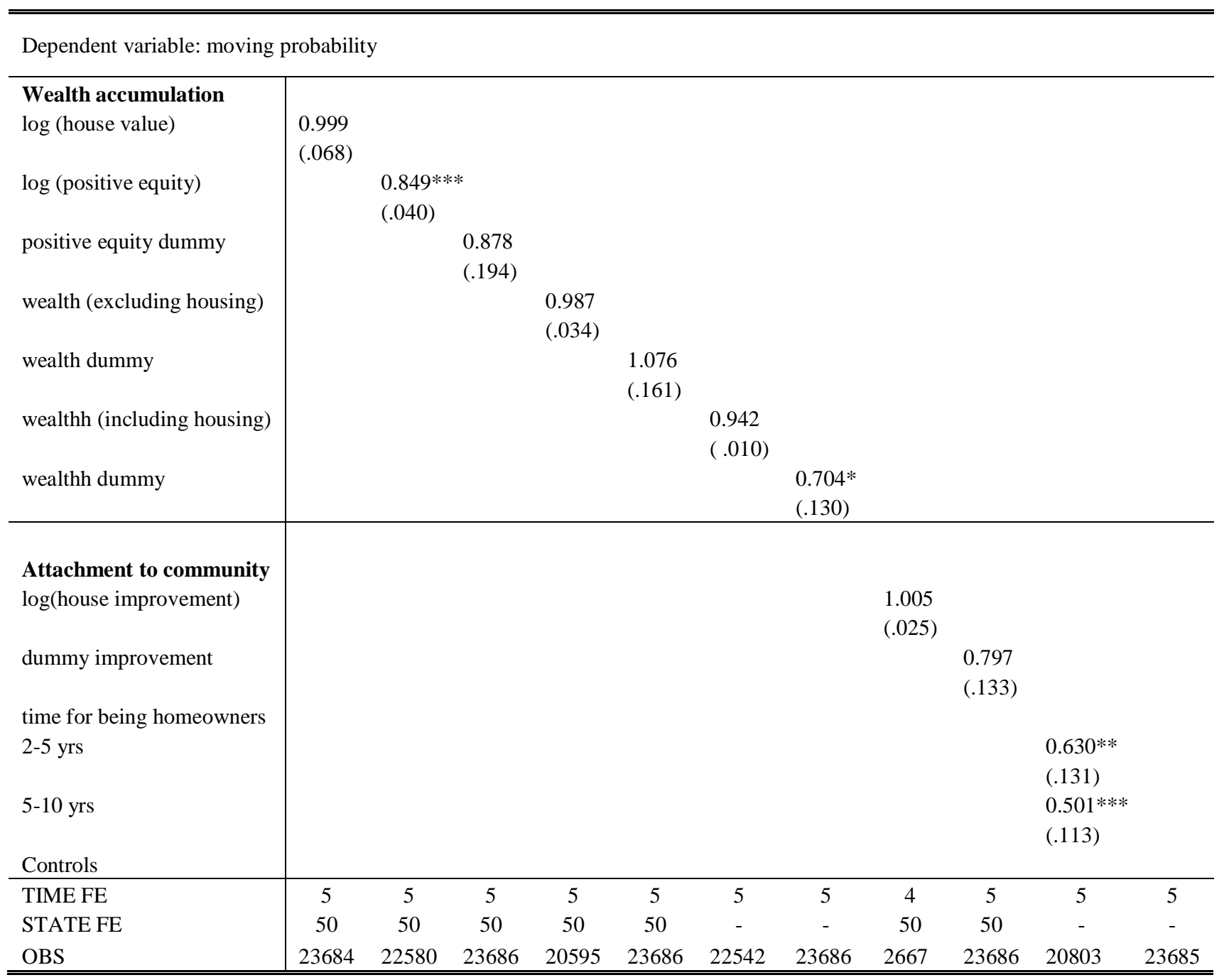

Note: we use the annual PSID data from 2001 to 2011 for this multinomial logit estimation. Only owners are included. The dependent variable is the probability of moving. The independent variables of interest are the wealth and attachment to community. The wealth includes log of the house value, log of the positive equity value, positive equity dummy, $\log$ of the wealth value without housing and its dummy, and log of the wealth with housing and its dummy. The dummy is whether the owner has non-negative wealth or not. The attachment to community includes $\log$ of the improvement value that the owner made to their property and its dummy, and the time of being homeowners. We only report the coefficients for job moves. Controls include age, marriage, children number, sex, education, population, and race. Coefficients less than one mean that people are less likely to move for jobs with the increase of right hand side variables. Standard errors are clustered at the individual level and are in parentheses. Significance level: $* * * \mathrm{p}<0.01, * * \mathrm{p}<0.05, * \mathrm{p}<0.1$ 
Table 28: Mortgage's effect on owner's mobility with SIPP data

\begin{tabular}{l|cccc}
\hline \hline $\begin{array}{l}\text { Moving } \\
\text { probability }\end{array}$ & $\begin{array}{c}\text { (1) Moved, same } \\
\text { county }\end{array}$ & $\begin{array}{c}\text { (2) Moved, different counties within } \\
\text { same state }\end{array}$ & $\begin{array}{c}\text { (3) Moved, different } \\
\text { states }\end{array}$ & Obs \\
\hline $2008-2013$ & 0.967 & $2.625^{* * *}$ & $3.205^{* * *}$ & 1186541 \\
& $(.217)$ & $(.579)$ & $(.811)$ & \\
$2004-2006$ & 1.258 & .584 & .824 & 783085 \\
& $(.218)$ & $(.221)$ & 1.118 & 608503 \\
$2001-2003$ & $.620^{*}$ & $1.997^{* *}$ & $(.504)$ & \\
\hline
\end{tabular}

Note: we use the monthly SIPP data of the panels of 2001, 2004 and 2008 for this multinomial logit estimation. Only owners are included. The dependent variable is the probability of moving with four categories: the base is not move; the first is the moving within the same county in column (1); the second is the moving to different counties but within the same state in (2); the third is the moving to different states in (3). The independent variable of interest is the mortgage dummy. Coefficients larger than one mean that people are more likely to move in the presence of mortgages. Standard errors are clustered at the individual level and are in parentheses. Significance level: $* * * \mathrm{p}<0.01, * * \mathrm{p}<0.05, * \mathrm{p}<0.1$ 
Appendix 1: SIPP summary statistics

\begin{tabular}{|c|c|c|c|c|}
\hline Variables & (1) Census & (2) Whole Sample & (3) Owners & (4) Renters \\
\hline \multicolumn{5}{|l|}{ Dependent variables: } \\
\hline Unemployment rate & $8.20 \%$ & $8.08 \%$ & $7.35 \%$ & $9.81 \%$ \\
\hline Unemployment spell (months) & & 1.76 & 1.61 & 2.12 \\
\hline Employment spell (months) & & 37.28 & 38.74 & 33.86 \\
\hline \multicolumn{5}{|l|}{ Move } \\
\hline 1 Non-mover & - & $97.54 \%$ & $98.98 \%$ & $94.14 \%$ \\
\hline 2.Moved, same county & - & $1.64 \%$ & $0.67 \%$ & $3.91 \%$ \\
\hline 3.Moved, different county within same state & - & $0.49 \%$ & $0.23 \%$ & $1.12 \%$ \\
\hline 4.Moved, different state & - & $0.33 \%$ & $0.12 \%$ & $0.83 \%$ \\
\hline \multicolumn{5}{|l|}{ Independent variables } \\
\hline Homeowners & $65.40 \%$ & $70.25 \%$ & - & - \\
\hline \multicolumn{5}{|l|}{ State home-ownership rates } \\
\hline$-65 \%$ & $20.00 \%$ & $26.86 \%$ & $24.08 \%$ & $33.43 \%$ \\
\hline $65 \%-70 \%$ & $44.00 \%$ & $42.80 \%$ & $43.50 \%$ & $41.16 \%$ \\
\hline $70 \%-$ & $36.00 \%$ & $30.34 \%$ & $32.43 \%$ & $25.42 \%$ \\
\hline \multicolumn{5}{|l|}{ Race } \\
\hline White & $72.41 \%$ & $81.43 \%$ & $85.18 \%$ & $72.56 \%$ \\
\hline Black & $12.61 \%$ & $11.65 \%$ & $8.54 \%$ & $18.98 \%$ \\
\hline Asian & $4.75 \%$ & $4.01 \%$ & $3.78 \%$ & $4.54 \%$ \\
\hline Latino & $16.40 \%$ & $2.92 \%$ & $2.49 \%$ & $3.93 \%$ \\
\hline Married & $58.95 \%$ & $54.17 \%$ & $61.76 \%$ & $36.24 \%$ \\
\hline Male & $49.20 \%$ & $51.06 \%$ & $50.76 \%$ & $51.78 \%$ \\
\hline \multicolumn{5}{|l|}{ City size } \\
\hline metro & - & $84.39 \%$ & $83.27 \%$ & $87.04 \%$ \\
\hline \multicolumn{5}{|l|}{ Education } \\
\hline High-school and lower & $58.41 \%$ & $68.11 \%$ & $64.73 \%$ & $76.09 \%$ \\
\hline Bachelor & $18.88 \%$ & $21.00 \%$ & $22.75 \%$ & $16.86 \%$ \\
\hline Master and above & $10.38 \%$ & $10.89 \%$ & $12.52 \%$ & $7.05 \%$ \\
\hline \multicolumn{5}{|l|}{ Age } \\
\hline $18-25$ & $9.90 \%$ & $14.50 \%$ & $12.70 \%$ & $14.50 \%$ \\
\hline $25-35$ & $22.16 \%$ & $22.70 \%$ & $18.08 \%$ & $22.70 \%$ \\
\hline $35-45$ & $22.16 \%$ & $23.31 \%$ & $23.53 \%$ & $23.31 \%$ \\
\hline $45-55$ & $24.29 \%$ & $24.16 \%$ & $27.22 \%$ & $24.16 \%$ \\
\hline $55-65$ & $19.69 \%$ & $15.33 \%$ & $18.47 \%$ & $15.33 \%$ \\
\hline \multicolumn{5}{|l|}{ Homeowner attributes } \\
\hline $\mid$ Negative equity $\mid>0$ & - & - & - & - \\
\hline Has mortgages & - & - & - & - \\
\hline
\end{tabular}

Note: The table reports the calculations of the SIPP data based on weights. Data is the 2008 panel, covering 2008 to 2013 . The first column (1) is from the 2012 census data. 
Appendix 2: SIPP result for other years

Unemployment hazard rates

\begin{tabular}{|c|c|c|c|c|c|c|}
\hline $\begin{array}{l}\text { Hazard rate from unemployment } \\
\text { to employment }\end{array}$ & PH (03-06) & PH (00-03) & $\mathrm{PH}(95-00)$ & PH - IV (03-06) & PH - IV (00-03) & PH - IV (95-00) \\
\hline Home-ownership & $\begin{array}{c}1.020 * * * \\
(.002)\end{array}$ & $\begin{array}{c}1.029 * * * \\
(.005)\end{array}$ & $\begin{array}{c}1.012 * * * \\
(.002)\end{array}$ & $\begin{array}{c}.986 * * * \\
(.004)\end{array}$ & $\begin{array}{c}1.031 * * * \\
(.005)\end{array}$ & $\begin{array}{c}1.031 * * * \\
(.004)\end{array}$ \\
\hline TIME FE & 36 & 36 & 47 & 36 & 36 & 47 \\
\hline STATE FE & 50 & 50 & 50 & 50 & 50 & 50 \\
\hline
\end{tabular}

Note: We use SIPP monthly data with panels of 1996 (95-00), 2001 (00-03) and 2004 (03-06) for this estimation. The dependent variable is the hazard rate from unemployment to employment. We use the specifications of $\mathrm{PH}$ model with Weibull distribution for baseline hazard and its IV. The instrument is the marginal tax rate for homeownership. Coefficients larger than one mean that people are more likely to leave unemployment for being owners. Standard errors are clustered at the individual level and are in parentheses. Significance level: $* * * \mathrm{p}<0.01, * *$ $\mathrm{p}<0.05, * \mathrm{p}<0.1$

Unemployment spells

\begin{tabular}{l|cccccc}
\hline \hline Unemployment spells & OLS (03-06) & OLS (00-03) & OLS (95-00) & OLS-IV (03-06) & OLS-IV (00-03) & OLS-IV (95-00) \\
\hline Home-ownership & $-.042 * * *$ & $-.023 * * *$ & $-.026 * * *$ & -.006 & $-.019 * *$ & $-.025 * * *$ \\
& $(.005)$ & $(.005)$ & $(.005)$ & $(.008)$ & $(.008)$ & $(.007)$ \\
\hline TIME FE & 36 & 36 & 47 & 36 & 56 & 50 \\
STATE FE & 50 & 50 & 50 & 1293708 & 1036954 & 1600775 \\
Obs & 1293708 & 1036954 & 1600775 & 50 & 57 \\
\hline \hline
\end{tabular}

Note: We use SIPP monthly data with panels of 1996 (95-00), 2001 (00-03) and 2004 (03-06) for this estimation. The dependent variable is unemployment spell length. We use OLS and IV specifications. The instrument is the marginal tax rate for home-ownership. Negative coefficients mean that people have shorter unemployment spells for being owners. Standard errors are clustered at the individual level and are in parentheses. Significance level: $* * * \mathrm{p}<0.01, * * \mathrm{p}<0.05, * \mathrm{p}<0.1$ 
Employment hazard rates

\begin{tabular}{|c|c|c|c|c|c|c|}
\hline $\begin{array}{l}\text { Hazard rate from employment } \\
\text { to unemployment }\end{array}$ & PH (03-06) & PH (00-03) & PH (95-00) & PH - IV (03-06) & $\mathrm{PH}-\mathrm{IV}(00-03)$ & $\mathrm{PH}$ - IV (95-00) \\
\hline Home-ownership & $.849 * * *$ & $.908 * * *$ & $.890 * * *$ & $.956 * *$ & .999 & .978 \\
\hline TIME FE & 36 & 36 & 47 & 36 & 36 & 47 \\
\hline STATE FE & 50 & 50 & 50 & 50 & 50 & 50 \\
\hline
\end{tabular}

Note: We use SIPP monthly data with panels of 1996 (95-00), 2001 (00-03) and 2004 (03-06) for this estimation. The dependent variable is the hazard rate from employment to unemployment. We use the specifications of $\mathrm{PH}$ model with Weibull distribution for baseline hazard and its IV. The instrument is the marginal tax rate for home-ownership. Coefficients less than one mean that people are less likely to leave employment for being owners. Standard errors are clustered at the individual le vel and are in parentheses. Significance level: $* * * p<0.01, * * p<0.05, * p<0.1$

Employment spells

\begin{tabular}{l|cccccc}
\hline \hline \multirow{2}{*}{ Employment spells } & OLS (03-06) & OLS (00-03) & OLS (95-00) & OLS-IV (03-06) & OLS-IV (00-03) & OLS-IV (95-00) \\
\hline Home-ownership & $1.140 * * *$ & $.928^{* * *}$ & $1.577 * * *$ & $.630 * * *$ & $-.169 *$ & .034 \\
& $(.058)$ & $(.066)$ & $(.079)$ & $(.097)$ & $(.100)$ & $(.117)$ \\
\hline TIME FE & 36 & 36 & 47 & 36 & 36 & 47 \\
STATE FE & 50 & 50 & 50 & 50 & 50 & 50 \\
Obs & 1293708 & 1036954 & 1542950 & 1293708 & 1036954 & 1542950 \\
\hline \hline
\end{tabular}

Note: We use SIPP monthly data with panels of 1996 (95-00), 2001 (00-03) and 2004 (03-06) for this estimation. The dependent variable is employment spell length. We use OLS and IV specifications. The instrument is the marginal tax rate for home-ownership. Positive coefficients indicate that people have longer employment spells for being owners. Standard errors are clustered at the individual level and are in parentheses. Significance level: $* * * p<0.01, * * p<0.05, * p<0.1$ 
The impact of home-ownership on mobility for other panels of SIPP

\begin{tabular}{l|ccccccc}
\hline \hline $\begin{array}{l}\text { Moving } \\
\text { probability }\end{array}$ & $\begin{array}{c}\text { (1) Moved, } \\
\text { same county }\end{array}$ & $\begin{array}{c}\text { (2) Moved, different } \\
\text { counties within same } \\
\text { state }\end{array}$ & $\begin{array}{c}\text { (3) Moved, } \\
\text { different states }\end{array}$ & (4) IV & (5) IV & (6) IV & Obs \\
\hline $2008-2013$ & $.250^{* * *}$ & $.293^{* * *}$ & $.260^{* * *}$ & $1.031^{* * *}$ & $1.377 * * *$ & $1.283^{* * * *}$ & 1704276 \\
& $(.003)$ & $(.006)$ & $(.007)$ & $(.019)$ & $(.047)$ & $(.056)$ & \\
$2004-2006$ & $0.282^{* * *}$ & $0.379 * * *$ & $0.296^{* * *}$ & $1.167 * * *$ & $1.144 * * *$ & 1.022 & 1094934 \\
& $(.004)$ & $(.008)$ & $(.009)$ & $(.026)$ & $(.043)$ & $(.055)$ & \\
$2001-2003$ & $0.281^{* * *}$ & $0.33^{* * *}$ & $0.268^{* * *}$ & $1.077 * * *$ & 1.057 & $1.111^{*}$ & 907215 \\
& $(.004)$ & $(.010)$ & $(.010)$ & $(.026)$ & $(.049)$ & $(.067)$ & \\
\hline
\end{tabular}

Note: We use the panels of 2001, 2004 and 2008 of SIPP monthly data for this multinomial logit estimation. The dependent variable is "move" with four categories: the base is not move; the first is the moving within the same county in column (1); the second is the moving to different counties but within the same state in (2); the third is the moving to different states in (3). (4), (5) and (6) are the IVs for (1), (2) and (3) with marginal tax rate as the instrument for home-ownership. Coefficients larger than one indicate that people are more likely to move if they are owners compared to renters. Standard errors are clustered at the individual level and are in parentheses. Significance level: $* * * \mathrm{p}<0.01, * * \mathrm{p}<0.05, * \mathrm{p}<0.1$ 